RFP-2836/3533/78/3

\title{
A GUIDE TO COMMERCIALLY AVAILABLE WIND MACHINES
}

April 3, 1978

\section{MASTER}

Work Performed Under Contract No. EY-76-C-04-3533

The Wind Systems Program

Rockwell International

Rocky Flats Plant

Golden, Colorado
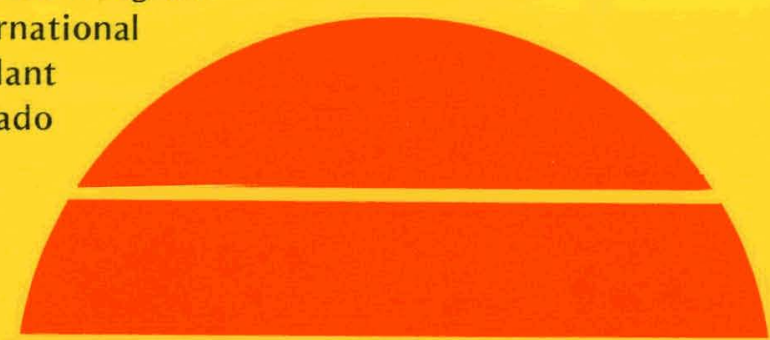

\section{U.S. Department of Energy}




\section{DISCLAIMER}

This report was prepared as an account of work sponsored by an agency of the United States Government. Neither the United States Government nor any agency Thereof, nor any of their employees, makes any warranty, express or implied, or assumes any legal liability or responsibility for the accuracy, completeness, or usefulness of any information, apparatus, product, or process disclosed, or represents that its use would not infringe privately owned rights. Reference herein to any specific commercial product, process, or service by trade name, trademark, manufacturer, or otherwise does not necessarily constitute or imply its endorsement, recommendation, or favoring by the United States Government or any agency thereof. The views and opinions of authors expressed herein do not necessarily state or reflect those of the United States Government or any agency thereof. 


\section{DISCLAIMER}

Portions of this document may be illegible in electronic image products. Images are produced from the best available original document. 


\section{NOTICE}

This report was prepared as an account of work sponsored by the United States Government. Neither the United States nor the United States Department of Energy, nor any of their employees, nor any of lleis contractors, subcontractors, or their emplovees, makes any warranty, express or implied, or assumes any legal liability or responsibility for the accuracy, completeness or usefulness of any information, apparatus, product or process disclosed, or represents that its use would not infringe privately owned rights.

This report has been reproduced directly from the best available copy.

Available from the National Technical Information Service, U. S. Department of Commerce, Springfield, Virginia 22161.

Price: Paper Copy $\$ 7.25$

Microfiche $\$ 3.00$ 
A GUIDE TO COMMERCIALLY

AVAILABLE

WIND MACHINES

3 April 1978

By

The Wind Systems Program

Rockwell International

Rocky Flats Plant

Prepared with the Assistance of

The Amprican Wind Energy Associatiun

Under Contract \#PF 71789F

\footnotetext{
for

The United States Department of Energy

Division of Solar Technology

Federal Wind Energy Program

Contract No. $E(29-2)-3533$
}

This report prepared as an account of work Government. Neither the

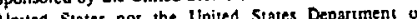
Ener Energy, nor sny of thetr enployees, hor any of their contractors, subcontractors, or the any wartanty, express or implied, or ascy liability or responsibily for the acenach, comple or usefulness of any information, apparatus, produet or process disclosed, or represents that its use would not infringa privitely owned right 


\title{
TABLE OF CONTENTS
}

\author{
Description
}

Page Number

Notice

Abstract

Introduction

Chapter One

Wind Power and the Wind Energy Conversion

3

System (WECS)

Power Production from the Wind Energy

4

Conversion System (WECS)

Power Available in the Wind 4

Power Extracted 6

Design Characteristics of Wind Machines 6

Tip Speed Ratio 6

Solidity Ratio 7

Estimating Power Production at a Specific 8

Site

Chapter Two Definition of Terms 12

Physical Characteristics 13

Operational Characteristics 15

Performance Characteristics 18

Chapter Three Wind Machine Data 24

Electrical Wind Machine Data 27

Mechánical Wind Machine Data 78

Appendix A: WECS Manufacturers and Dealers/Distributors 99

Appendix B: Subsystem Components and Suppliers 107

$\begin{array}{ll}\text { Anemometers } & 108\end{array}$

WTG Towers 109

Batteries $\quad 110$

Inverters 111 


\section{TABLE OF CONTENTS (Continued)}

\section{Description}

Appendix C: $\quad$ Selected References on WECS

Figure 1.1 WECS Schematic 5

Figure 1.2 Power Coefficient vs. Tip Speed Ratio 6

Figure 1.3 Solidity Ratio vs. Tip Speed Ratio 7

Figure 1.4 Power Output vs. Wind Speed 8

Figure 2.1 Taxonomy of Wind Turbines 14

Figure 2.2 Taxonomy of Wind Turbines (continued) 15

TABLE 3.1 Summary-Electrical Wind Machines 27

TABLE 3.2 Summary-Mechanical Wind Machines 78 


\section{ABSTRACT}

This report describes in detail Wind Energy Conversion Systems (WECS) commercially available in the United States. The terms used to describe these wind systems are defined and their significance discussed. Lists of manufacturers and distributors, subsystem components and suppliers, and references are provided. 


\section{INTRODUCTION}

This report was prepared to provide a description of small wind machines (under $100 \mathrm{kw}$ capacity) commercially available in the United States. The main focus is on machines that might be used to furnish a home, farm, small business, or remote facility with some or all of its electrical power. Other wind machines, designed to produce mechanical power, are also described.

In general, this report answers four primary questions:

- What wind machines are available?

- What are their performance characteristics?

- What are the differences among these wind machines?

- Where can wind machines and associated equipment be purchased?

A total of 66 wind machines from 28 manufacturers are described. The manufacturers provided a data sheet for each machine, describing its physical, performance and operational characteristics. Two summary charts, one for electrical machines and one for mechanical machines, are included to facilitate comparison. All wind systems whose manufacturers provided information by June 31, 1978 are included.

Most of the wind machines described are currently available in the United States. A number of others are now in the prototype or design stage (and noted as such) and will be available shortly.

While this report is primarily concerned with describing the wind machine, additional components required to complete the total wind energy conversion system (towers, storage systems, and inverters), are briefly described.

In addition, a glossary of terms and a discussion of wind technology basics are included to help the reader evaluate the machines. A list of selected references is provided for readers wishing further information on wind energy utilization.

\section{How to Use This Book}

The major points of comparison for evaluating the wind machines in this book are rated output and rated wind speed (both of which are selected by the manufacturer as being representative of a machine's optimum performance - i.e. $25 \mathrm{~kW} @ 20 \mathrm{mph}$ ), and cut-in and cut-out wind speed (the points at which the machine begins and stops producing power). In selecting a wind machine, these performance and operational characteristics should be matched with the wind conditions at the site and the energy requirements of a particular application.

Wind conditions are most accurately determined by taking wind speed measurements at the site using an anemometer. A list of companies which 
manufacture and/or distribute anemometry equipment is included on page 108. Data from nearby airports or other wind measurement sites may be used to determine typical average wind speeds for a general regional (see references in Appendix $C$ ) but this data may not be applicable to a specific site.

A current utility bill, which lists the amount of power (in kilowatt hours) consumed during the billing period, is a readily available source for estimating the output capabilities needed in a machine. The Consumer Service Department of a local utility company can provide any further information needed to assess a particular energy requirement. A method for combining the wind conditions at a particular site with a machine's rated output (which is given in watts or kilowatts) to obtain an estimate of the kilowatt hours to expect from a machine at a particular site is given on pages $8-11$. This estimate should aid the reader in selecting machines that would meet his energy requirements.

Once a llachine has bcen selected, the distributor or manufacturer can provide assistance in putting together a total wind system best suited lu a particular sitc, applicatim, and budqet. The service provided by local dealers is generally considered beneficial because of their faml iiarity with local wind conditions and their accessibility for later service. For this reason, most manufacturers do not sell directly to the public when dealerships have been established. 
CHAPTER ONE:

WIND POWER AND THE

WIND ENERGY CONVERSION SYSTEM (WECS.) 


\section{POWER PRODUCTION FROM THE WIND ENERGY CONVERSION SYSTEM (WECS)}

This report is primarily concerned with describing the wind machine, which is the equipment at the top of a wind system's tower.

The wind machine, however, is only one component in a WECS. Its performance cannot be defined independent of the system's other elements: The wind, or the WECS "fuel supply"; and the load, or manner in which the energy produced is used. All three elements, taken together, determine how much usable energy a system will produce. Figure 1.1 is schematic representation of a WECS.

The wind, although remarkably constant over long periods of time, is extremely variable in speed and direction. Wind machines are designed to compensate for these complexities in the wind. Yaw, over-speed and voltage control mechanisms (see Chapter Two for definiations of these terms) are examples of machine features that help compensate for the constant vartaliuls in operating conditions to ensure reliable system performance.

Because the power in the wind varies with the third power of the wind velocity (doubling the wind speed results in eight times the power), even small fluctuations in the wind speed can result in greatly differen power outputs. In addition, constant changes in the wind direction make it difficult to precisely determine the wind speed and, therefore, the power available at any moment. The rate of change in both wind speed and direction varies greatly from site to site. This kind of variabilit: in the wind makes it difficult to predict a standard performance level for a wind machine and the total WECS.

The load on a WECS also affects the amount of energy that a system will yield. A wind system feeding power into a battery bank, for example, will have different performance characteristics than a system feeding a utility line or resistance heater.

Wind machine dealers are knowledgeable in the complexities of the WECS and can help assess the wind conditions at a particular site and the load as parts of the system.

\section{POWER AVATLABLE IN THE WIND}

The power available to a wind machine for conversion to useful energy is a function of the area intercepted by the blades, ajr density and wind speed. Hower Available (Pav) Area $\times$ (Wind Speed) $\times k$, where $k=a$ mathematical constant for various units of power, area and velocity, incorporating the value of air density at .00237 slugs $/ \mathrm{ft}^{3}$ (the density of air at sea level and $59^{\circ} \mathrm{F}$ ). Different values of $k$ for various units of power, area and velocity are: 
Figure 1.1

WIND

(KINETIC ENERGY)

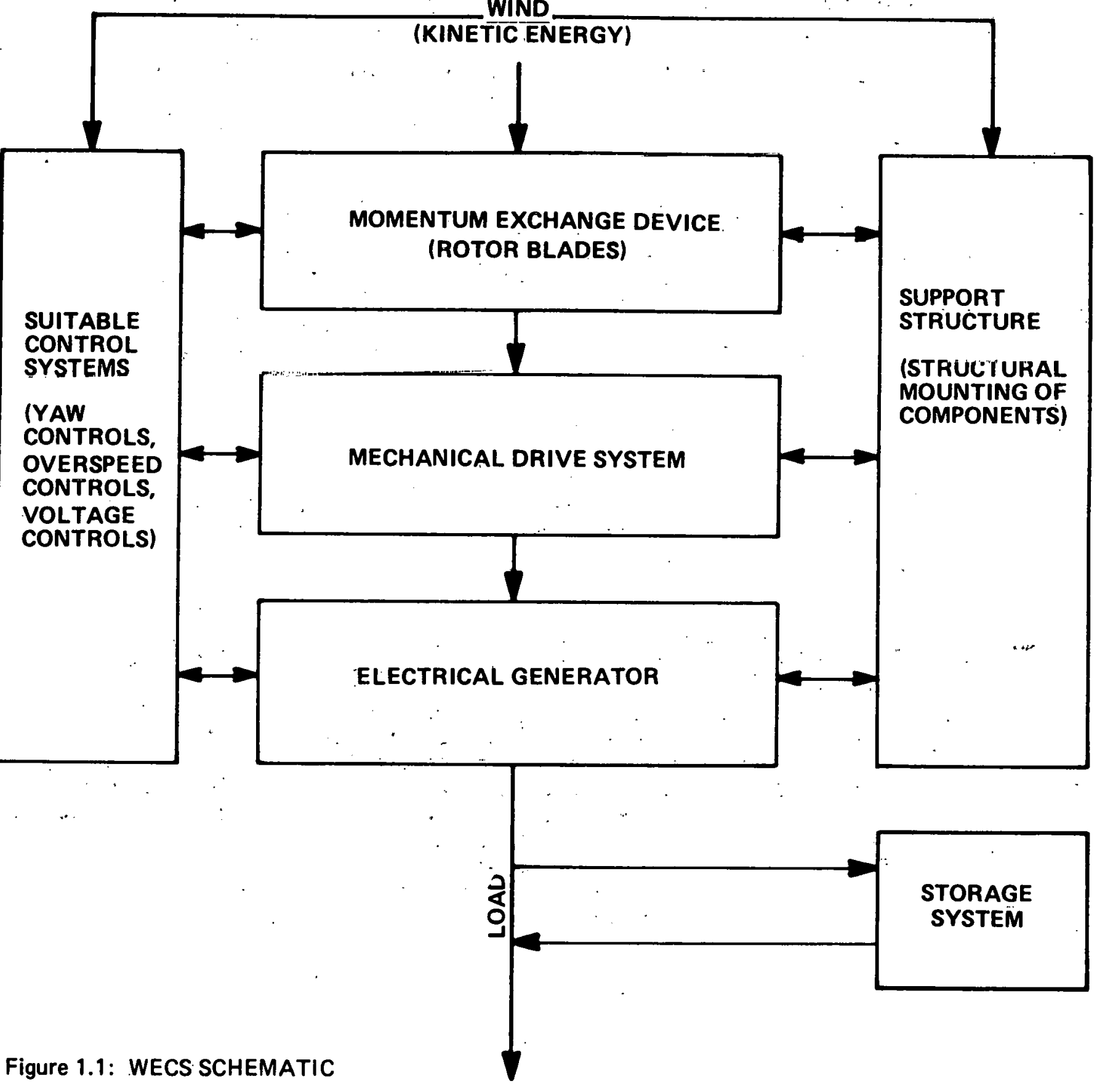




\begin{tabular}{llll}
\multicolumn{1}{c}{ Power } & \multicolumn{1}{c}{ Area } & \multicolumn{1}{c}{ Velocity } & $\frac{\text { Constant }(\mathrm{k})}{\text { kilowatt }}$ \\
kilowatt & sq. feet & miles per hour, & $5.1 \times 10^{-6}$ \\
kilowatt & sq. feet & knots & $7.7 \times 10^{-6}$ \\
horsepower & sq. feet & meters per second & $6.1 \times 10^{-4}$ \\
watts & sq. feet & feet per second & $1.6 \times 10^{-3}$
\end{tabular}

\section{POWER EXTRACTED}

The percentage of available power which a wind machine rotor extracts from the wind is known as the Power Coefficient ( $C p)$. It is simply the ratio between the nnwer extracled alid the power available. The thenretical llidximum $C p$ is .593. This value is referred to as the betz $11 \mathrm{~m} 1 \mathrm{t}$. In practice, power coefficients normally range from . 148 for Savonious rotors, to .459 for propeller-type rotors. The power coefficient does not include losses from the drive train, generator, or other subsystems.

\section{DESIGN CHARACTERISTICS OF WIND MACHINES}

A particular design can be described in terms of its power cuefficient, or efficiency in extracting energy; its tip speed ratio (or speed of rotation relative to the wind); and its solidity, which determines the wind speed operating range.

\section{Tip Speed Ratio}

The tip speed ratio is a characteristic of a machine's design which influences its power coefficient. It is the ratin of the velocity at the tip of the blade to the velocity of the wind. High tip speed ratios range between 5 and 10 , while low tip speed ratios fall between 1 and 2. Wind machines with low tip speed ratios usually have higher starting t.orques (start rotating at lower wind speeds), but their blades never reach high speeds. This makes them best suited for mechanical applications such as pumping water. Machines with high tip speed ratios have tip speeds 5 to 10 times faster than the wind, which makes them well suited. for electricity production. The following chart illustrates that highest power coefficient values occur at high tip speed ratios. 


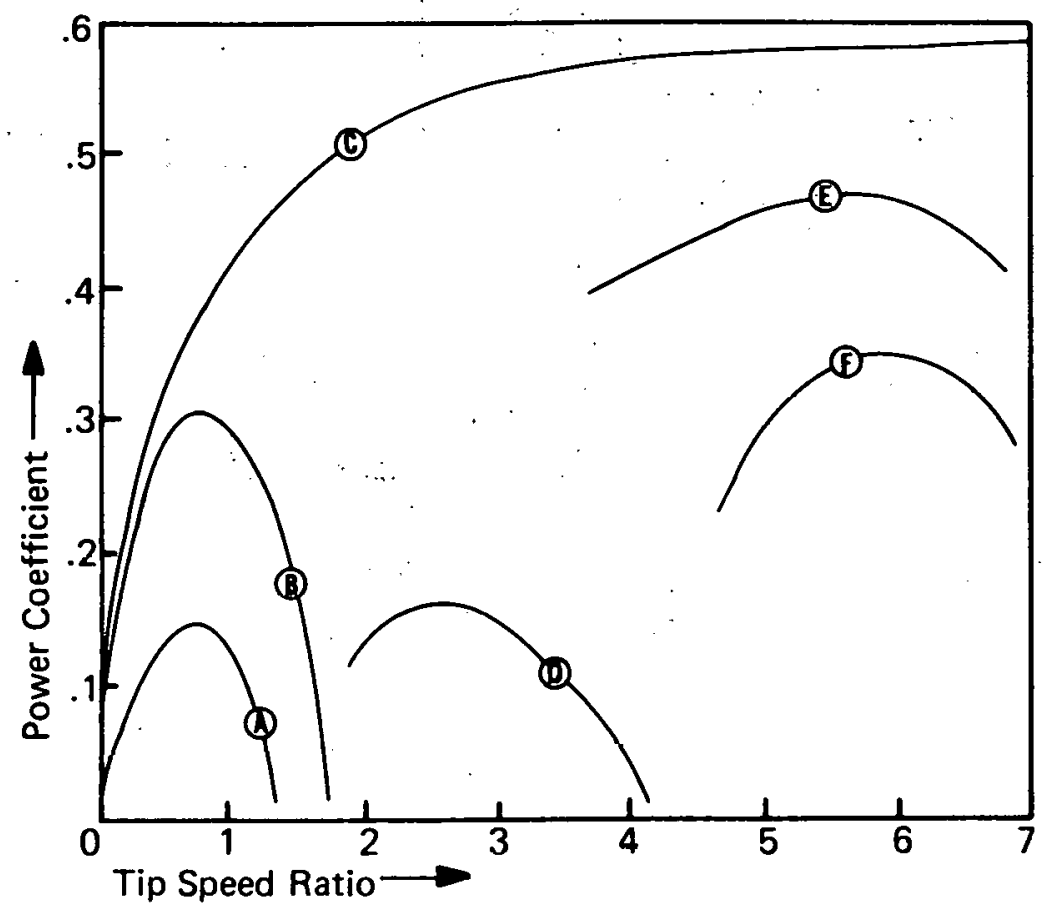
A. Savonius rotor
B. American multi-blade type
C. Ideal efficiency for propeller type windmills
D. Dutch four arm type
E. High speed two blade type
F. Darrieus rotor

Figure 1.2: POWER COEFFICIENT VS. TIP SPEED RATIO

\section{Solidity Ratio}

Solidity Ratio is another characteristic of wind machine design that influences performance efficiency. It is lhe ratto of blade surface area to the area swept by the blades. Machines that sweep out a larger area in relation to the surface area of their blades have a low solidity ratio and are more efficient. Increased solidity lowers the tip speed radio and raises starting torque. Relationships between solidity ratio and tip speed radio are shown in Figure 1.3. 


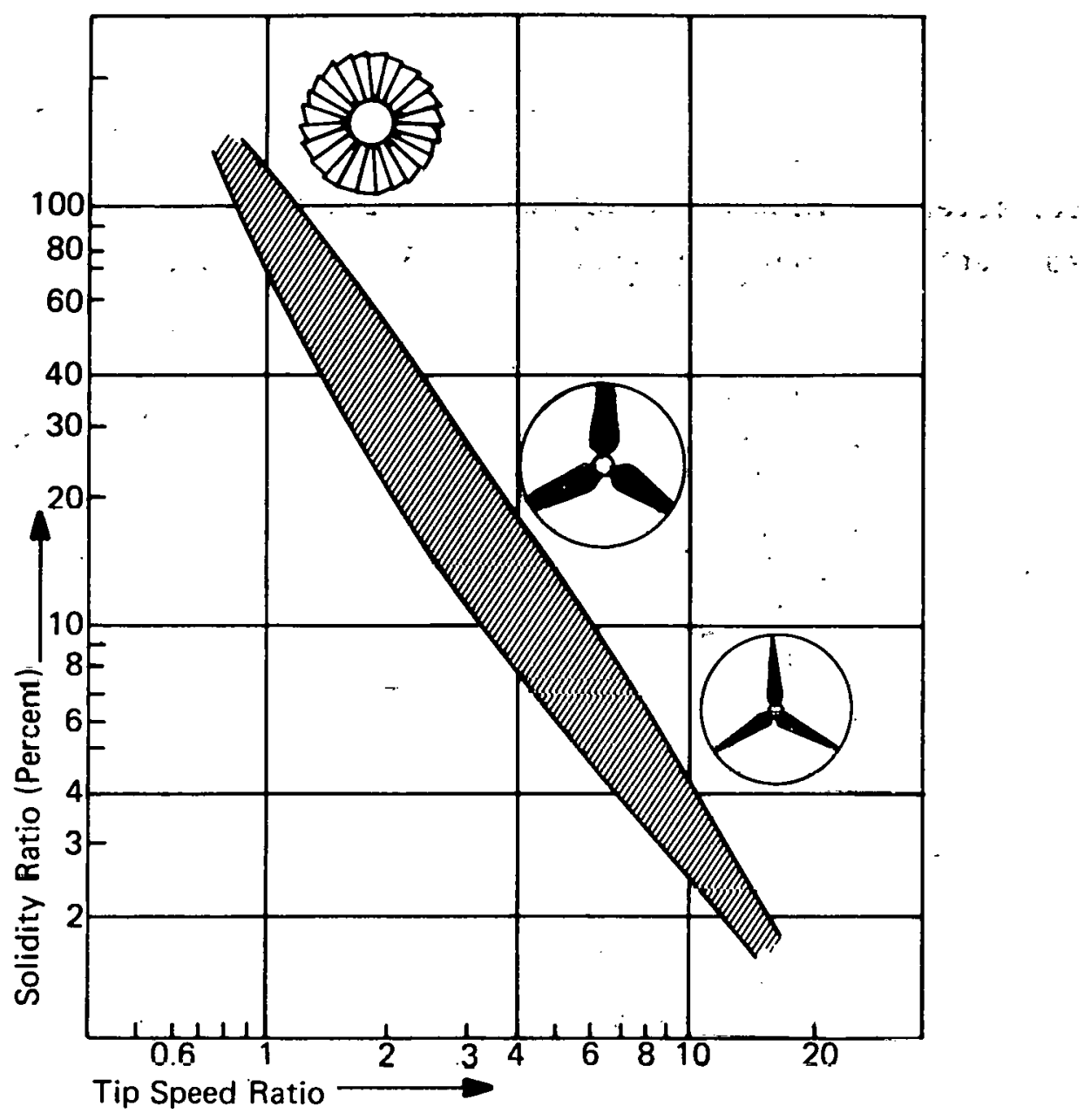

Figure 1.3: SOLIDITY RATIO VS. TIP SPEED RATIO

\section{ESTIMATING PUWER PRODUCTION AT A SPECIFIC SITE}

There are differences of opinion concerning the must accurate method for predicting how much energy a wind machine will produce at a given site. The intention here is to provide a simplified method for translating the wind machine power data given in the manufacturer's descriptions into more explicit terms: $\mathrm{kW}$ hours of production per year or month for a specific site.

This methodology yields only a rough estimate of expected energy production, but it is valuable because it combines a machine's power curve and the wind profile at the site in question to provide a tangible picture of how much electrical or mechanical power a machine will furnish. Accordingly, it shows how the machine could fit into an energy user's total store of fuel. 
To use this method, it is necessary to have wind velocity data detailing the percentage of time different wind speeds occur at the site in question. Figure 1.4 is a velocity distribution chart for sites with $8.95 \mathrm{mph}$ $(4 \mathrm{~m} / \mathrm{s}), 11.8 \mathrm{mph}(5 \mathrm{~m} / \mathrm{s})$, and $13.42 \mathrm{mph}(6 \mathrm{~m} / \mathrm{s})$ annual average wind speeds. This chart includes high, medium, and low distribution patterns for each annual average wind speed, and illustrates the variability in wind profiles among sites with the same average wind speed. WIND VELOCITY DISTRIBUTIONS FOR THREE DIFFERENT AVERAGE
ANNUAL WIND SPEEDS

\begin{tabular}{|c|c|c|c|c|c|c|c|c|c|c|}
\hline \multirow{2}{*}{\multicolumn{2}{|c|}{$\begin{array}{l}\text { WIND } \\
\text { VELOCITY } \\
\text { READING }\end{array}$}} & \multicolumn{9}{|c|}{$\begin{array}{c}\text { PERCENTAGE OF HOURLY READINGS (PER YEAR) } \\
\text { WHEN EACH WIND VELOCITY OCCURRED }\end{array}$} \\
\hline & & \multicolumn{3}{|c|}{$\begin{array}{l}8.95 \mathrm{mph}(4 \mathrm{~m} / \mathrm{s}) \\
\text { Average Sites }\end{array}$} & \multicolumn{3}{|c|}{$\begin{array}{l}11.18 \mathrm{mph}(5 \mathrm{~m} / \mathrm{s}) \\
\text { Average Sites }\end{array}$} & \multicolumn{3}{|c|}{$\begin{array}{c}13.42 \mathrm{mph}(6 \mathrm{~m} / \mathrm{s}) \\
\text { Average Sites }\end{array}$} \\
\hline MPH & $\mathrm{M} / \mathrm{S}$ & $\mathrm{HIGH}$ & MED. & LOW & $\mathrm{HIGH}$ & MED. & LOW & $\mathrm{HIGH}$ & MED. & LOW \\
\hline $\begin{array}{r}2.2 \\
4.5 \\
6.7 \\
9.0 \\
11.2 \\
13.4 \\
15.7 \\
17.9 \\
20.1 \\
22.4 \\
24.6 \\
26.9 \\
29.1 \\
31.3 \\
33.6 \\
35.8 \\
38.0 \\
40.3 \\
42.5 \\
44.7\end{array}$ & $\begin{array}{r}1 \\
2 \\
3 \\
4 \\
5 \\
6 \\
7 \\
8 \\
9 \\
10 \\
11 \\
12 \\
13 \\
14 \\
15 \\
16 \\
17 \\
18 \\
19 \\
20\end{array}$ & $\begin{array}{c}14.8 \% \\
16.8 \% \\
15.8 \% \\
13.4 \% \\
10.6 \% \\
8.0 \% \\
5.8 \% \\
4.0 \% \\
2.7 \% \\
1.8 \% \\
1.1 \% \\
.7 \% \\
.4 \% \\
.2 \% \\
.1 \% \\
.1 \% \\
0 \% \\
0 \% \\
0 \% \\
0 \%\end{array}$ & $\begin{array}{c}10.6 \% \\
16.5 \% \\
18.3 \% \\
16.8 \% \\
13.5 \% \\
9.6 \% \\
6.2 \% \\
3.7 \% \\
2.0 \% \\
1.0 \% \\
.4 \% \\
.2 \% \\
.1 \% \\
0 \% \\
0 \% \\
0 \% \\
0 \% \\
0 \% \\
0 \% \\
0 \%\end{array}$ & $\begin{array}{r}8.5 \% \\
15.9 \% \\
19.4 \% \\
18.7 \% \\
15.1 \% \\
10.3 \% \\
6.1 \% \\
3.1 \% \\
1.4 \% \\
.6 \% \\
.2 \% \\
.1 \% \\
0 \% \\
0 \% \\
0 \% \\
0 \% \\
0 \% \\
0 \% \\
0 \% \\
0 \%\end{array}$ & $\begin{array}{r}9.2 \% \\
12.6 \% \\
13.8 \% \\
13.3 \% \\
11.9 \% \\
10.0 \% \\
8.0 \% \\
6.1 \% \\
4.5 \% \\
3.2 \% \\
2.2 \% \\
1.4 \% \\
.0 \% \\
.6 \% \\
.4 \% \\
.2 \% \\
.1 \% \\
.1 \% \\
0 \% \\
0 \%\end{array}$ & $\begin{array}{r}5.4 \% \\
12.6 \% \\
14.2 \% \\
15.7 \% \\
15.0 \% \\
12.8 \% \\
9.8 \% \\
6.8 \% \\
4.3 \% \\
2.5 \% \\
1.8 \% \\
1.3 \% \\
.8 \% \\
.1 \% \\
0 \% \\
0 \% \\
0 \% \\
0 \% \\
0 \% \\
0 \%\end{array}$ & $\begin{array}{r}4.1 \% \\
9.5 \% \\
14.2 \% \\
16.7 \% \\
16.5 \% \\
14.1 \% \\
10.5 \% \\
6.9 \% \\
3.9 \% \\
2.0 \% \\
.9 \% \\
.3 \% \\
.1 \% \\
0 \% \\
0 \% \\
0 \% \\
0 \% \\
0 \% \\
0 \% \\
0 \%\end{array}$ & $\begin{array}{r}5.7 \% \\
9.1 \% \\
11.1 \% \\
11.9 \% \\
11.7 \% \\
10.7 \% \\
9.4 \% \\
7.8 \% \\
6.2 \% \\
4.8 \% \\
3.5 \% \\
2.5 \% \\
1.7 \% \\
1.2 \% \\
.8 \% \\
.5 \% \\
.6 \% \\
.3 \% \\
.1 \% \\
.1 \%\end{array}$ & $\begin{array}{c}2.8 \% \\
6.6 \% \\
10.1 \% \\
12.7 \% \\
13.9 \% \\
13.6 \% \\
12.0 \% \\
9.7 \% \\
7.2 \% \\
4.8 \% \\
3.0 \% \\
1.7 \% \\
.9 \% \\
.4 \% \\
.2 \% \\
.1 \% \\
.1 \% \\
0 \% \\
0 \% \\
0 \%\end{array}$ & $\begin{array}{c}1.9 \% \\
5.5 \% \\
9.5 \% \\
12.9 \% \\
14.9 \% \\
15.0 \% \\
13.3 \% \\
10.5 \% \\
7.4 \% \\
4.6 \% \\
3.5 \% \\
1.2 \% \\
.5 \% \\
.2 \% \\
.1 \% \\
0 \% \\
0 \% \\
0 \% \\
0 \% \\
0 \%\end{array}$ \\
\hline & & $\begin{array}{l}\text { Me } \\
\text { energ } \\
\text { er pe } \\
\text { verag }\end{array}$ & $\begin{array}{l}\text { n, ar } \\
\text { aila } \\
\text { itage } \\
\text { inua }\end{array}$ & $\begin{array}{l}\text { w re } \\
\text { the } \\
\text { aster } \\
\text { d sp }\end{array}$ & $\begin{array}{l}\text { AR. } \\
\text { o the } \\
\text { incr } \\
\text { is wil } \\
\text { the s }\end{array}$ & ovide & $\begin{array}{l}\text { gy co } \\
\text { Ibe o } \\
\text { e ava }\end{array}$ & $\begin{array}{l}t \text { at } \\
\text { velo } \\
\text { ent }\end{array}$ & $\begin{array}{l}\text { site. } \\
\text { a si } \\
\text { ven }\end{array}$ & $\begin{array}{l}\text { ce } \\
\text { th a } \\
\text { ugh }\end{array}$ \\
\hline
\end{tabular}

Figure 1.4 
To develop an estimate of annual output, multiply the system output at each increment of wind speed by the percentage of time that increment occurs each year. Then add all of the resulting products together and multiply by the number of hours in one year (8760). For an example, consider a site at which the annual average wind speed is $11.18 \mathrm{mph}$ $(5 \mathrm{~m} / \mathrm{s})$. If we use the medium energy velocity distribtuion as shown in Figure 1.4, along with the power curve from a small wind machine as shown in Figure 1.5, the calculations would be as follows:

Figure 1.5

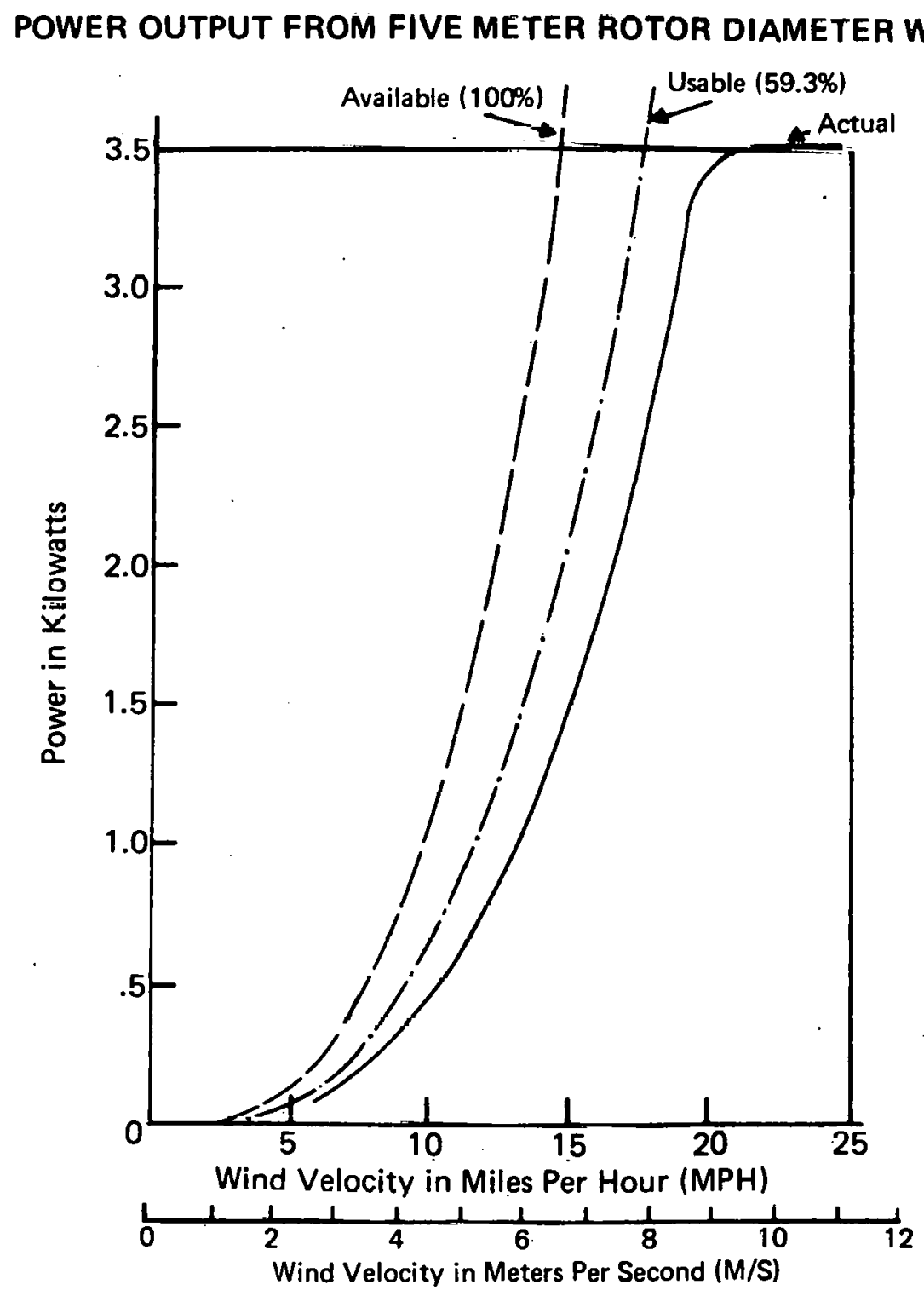

Figure 1.5 
ki lowatt hours per year $=$

$$
\begin{aligned}
& .32 \mathrm{~kW} \times 15.7 \%=.050 .4 \mathrm{~m} / \mathrm{s} \quad 3.50 \mathrm{~kW} \times 2.5 \%=.088 @ 10 \mathrm{~m} / \mathrm{s} \\
& .65 \mathrm{~kW} \times 15 \%=.098 @ 5 \mathrm{~m} / \mathrm{s} \quad 3.50 \mathrm{~kW} \times 1.8 \%=.063 @ 11 \mathrm{~m} / \mathrm{s} \\
& 1.15 \mathrm{~kW} \times 12.8 \%=.147 @ 6 \mathrm{~m} / \mathrm{s} \quad 3.50 \mathrm{~kW} \times 1.3 \%=.046 @ 13 \mathrm{~m} / \mathrm{s} \\
& 2.60 \mathrm{~kW} \times 9.8 \%=.172 @ 7 \mathrm{~m} / \mathrm{s} \quad 3.50 \mathrm{~kW} \times .8 \%=.028 @ 13 \mathrm{~m} / \mathrm{s} \\
& 3.45 \mathrm{~kW} \times 4.3 \%=.148 @ 9 \mathrm{~m} / \mathrm{s} \quad 3.50 \mathrm{~kW} \times .1 \%=.004 @ 14 \mathrm{~m} / \mathrm{s} \\
& \text { 3.45. } \mathrm{kW} \times 4.3 \%=.148 @ 9 \mathrm{~m} / \mathrm{s} \\
& \text { TOTAL }=1.019 \times 8760 \text { hours per year }= \\
& 8,856.360 \text { kilowatt hours per year }= \\
& 738.30 \text { kilowatt hours per month }
\end{aligned}
$$

It should be noted that winds below the cut-in wind speed are not used, and all winds above the rated wind speed are assumed to produce the rated power output of the generator.

Thie calculated uulput stiows only power available at the blades. Other factors that must be considered include the inevitable losses which occur in transmission, conversion and storage of energy and rotor power coefficient. (See discussion of power coefficient). In the case of batteries, only about $70 \%$ of the energy used in charging can be recovered during discharge.

For sites where only the annual average wind speed is known, the following equation will yield an estimate of power production:

$$
P=2 A V^{3} k
$$

where: $\quad A=$ area swept out by blades

$$
\begin{aligned}
& V=\text { annual average velocity in } \mathrm{mph} \\
& \mathrm{k}=5.1 \times 10^{-6}
\end{aligned}
$$

Again this equation only gives an estimate of the power available at the blades. And the variability in velocily distributions among sites with the same annual average (as illustrated in Figure 1.4) is a further limitation.

The United States Department of Energy's Rocky Flats Plant, managed by Rockwell International, has been designated as the lead agency in the country for the development and testing of small WECS. Data collerted by this facility will be included in later editions of this report, thus providing a further reference for assessing wind machine performance. Wind velocity data can be obtained from sources referenced in Appendix C. 
CHAPTER TWO:

DEFINITION OF TERMS

- $12-$ 
Terms which are used to describe systems that extract energy from the wind can, if not properly defined, adversely influence communications both within the wind energy industry and between the wind energy industry and the public.

Two acronyms are in wide-spread use within the field of wind energy utilization. These are Wind Energy Conversion Systems (WECS) and Wind Turbine Generators (WTGs). There are also a number of symbols and terms which appeared in the Proceedings of The Second Workshop on WECS and in Applied Aerodynamics of Wind Power Machines (see Appendix C).

The terms used in this guide to describe wind systems have been divided into three categories. The Physical Characteristics describe the type of system, rotor size, materials, and weights. The Operational Characteristics describe the WECS' operating range, type of generator or alternator, and control system. The Performance Characteristics describe the maximum and rated power, and power production vs. wind speed.

What follows is a list of the terms that have been used in assessing the wind energy conversion systems, together with their definitions and a brief dicussion of their significance.

\section{PHYSICAL CHARACTERISTICS}

Generic Description:

Definition

This describes the general type of system including type of extractor, such as propeller, Savonious, Darrieus, multi-rotor, contrarotating rotor, diffuser augmented, vortex augmented, tip-vane augmented, or concentrator. Axis of rotation (horizontal or vertical) is also given.

\section{Significance}

Each type of WLCS has individual operating characteristics which are dependent on its design. Each type has limitations on efficiency, speed of rotation, and type of applications to which it is best suited. For a pictorial description of the characteristics of the individual types, see Figures 2.1 and 2.2.

\section{Capture Area:}

\section{Definition}

The capture area is defined as $R^{2}$, where $R$ is the maximum blade radius for a WECS whose frontal silhouette is a circle. This would be the height times the width for a wind turbine whose frontal silhouette is a rectangle. 


\section{TAXONOMY}

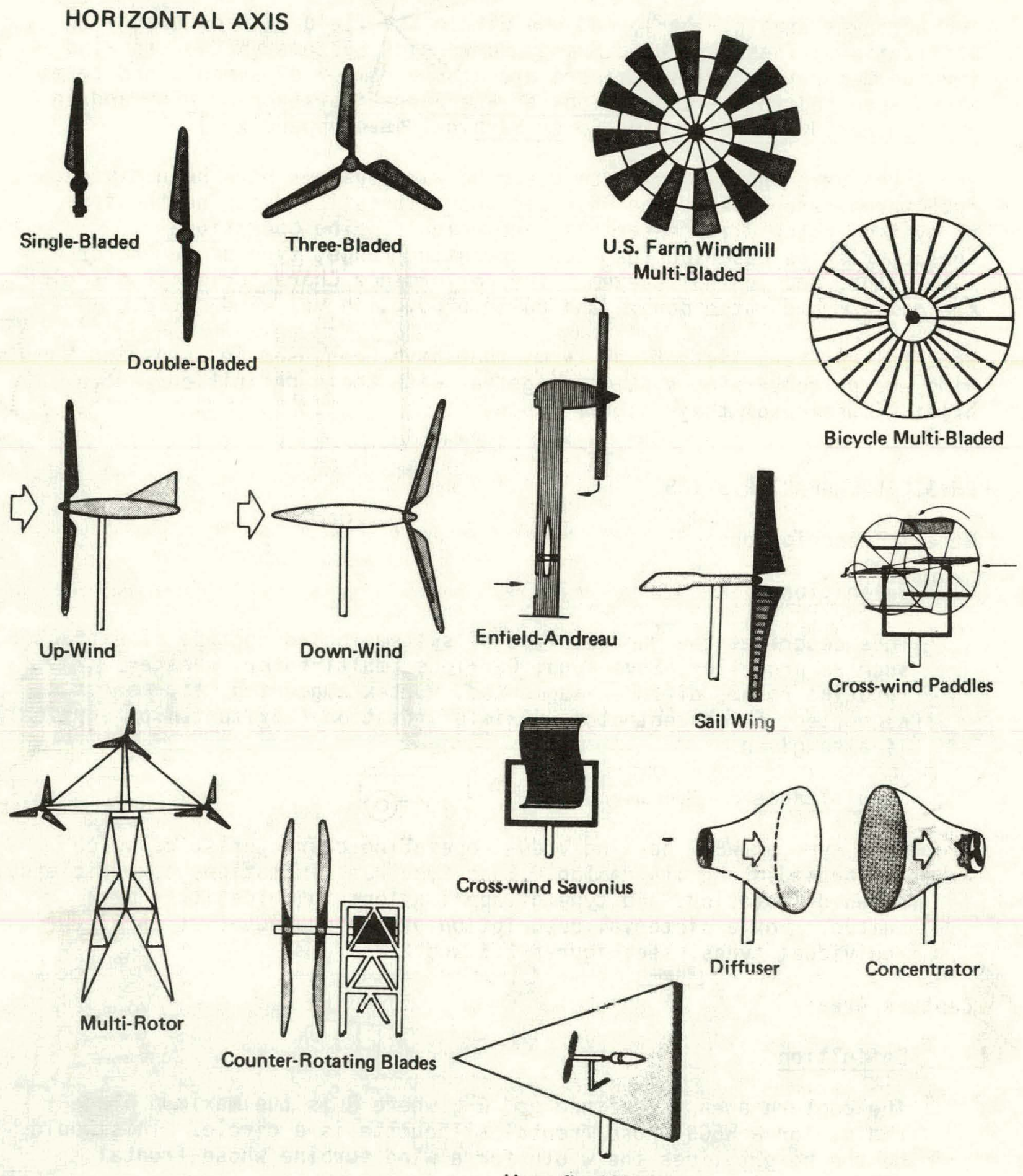

Unconfined Vortex

Figure 2.1 
VERTICAL AXIS

\section{PRIMARILY DRAG-TYPE}

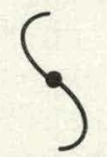

Savonius

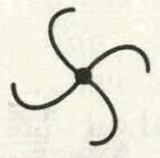

Multi-Bladed

Savonius

\section{TAXONOMY}

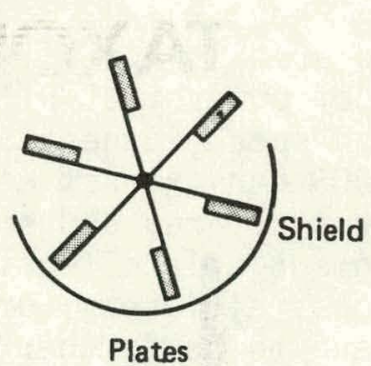

Cupped

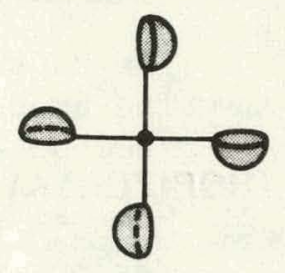

\section{PRIMARILY LIFT-TYPE}

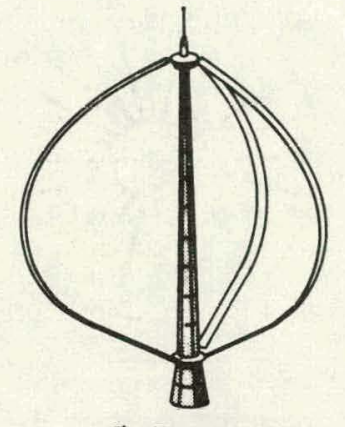

$\emptyset$ - Darrieus

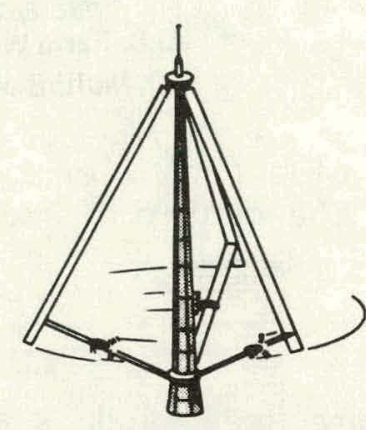

$\Delta$ - Darrieus

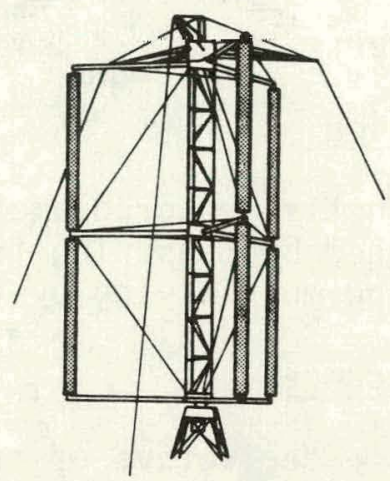

Giromill

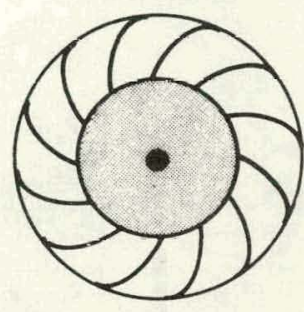

Turbine

\section{COMBINATIONS}

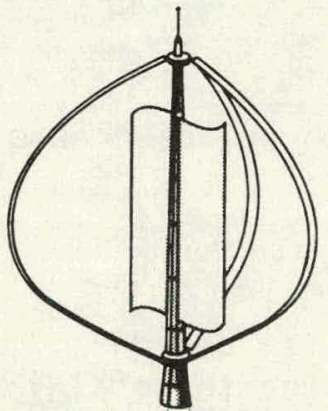

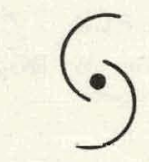

Split Savonius

Savonius/ $\emptyset$ - Darrieus
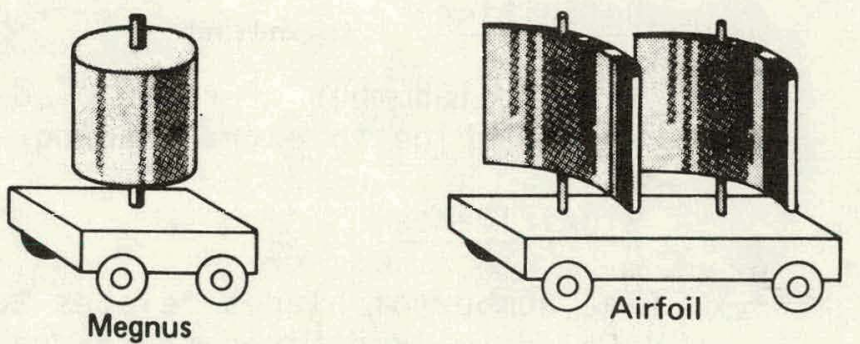

OTHERS

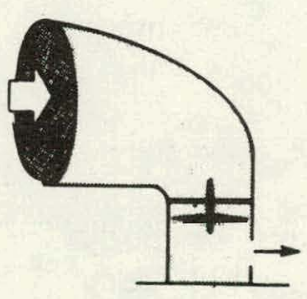

Deflector

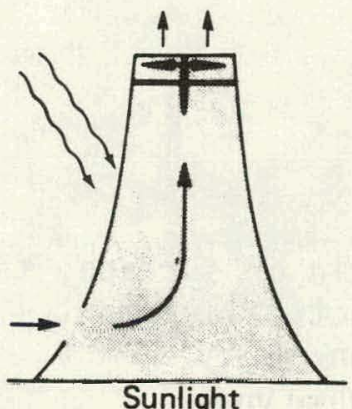

Sunlight

Our thanks to Mr. Frank Eldridge for permission to reprint these pages from his Wind Marhines (Reference 4).
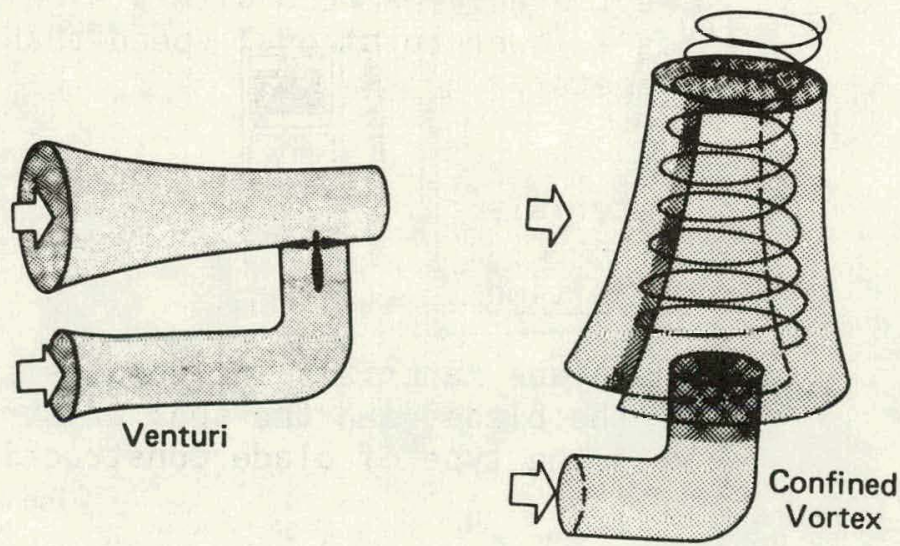

Figure 2.2 


\section{$\underline{\text { Significance }}$}

The capture area is one of the major limiting factors in determining the amount of power that will be produced by a WECS. Other factors include wind speed, generator capacity, and structural characteristics. A WECS can extract energy only from wind it is exposed to, both in terms of area and speed. It should be noted that various designs augment this effective capture area through the use of concentrators, diffusers, or multiple sets of propellers. This term may have to be further defined as more radical concepts in energy extraction are developed, but capture area will remain one of the major limiting factors to wind energy extraction.

Rotor Diameter:

Definition

The effective rotor diameter of a propeller-type wind turbine is determined hy measuring from the center of rotation to the tip of a blade and multiplying by two.

\section{Significance}

This is a derivative of capture area, and is a term commonly used in describing a horizontal axis WECS which uses propeller-type blades.

Blade Quantity:

Definition

The total number of rotor blades, of each type, which are used on a wind machine to extrac:l eneryy from the wind.

\section{Significance}

The number of blades relates to the solidity of a given design. (Solidity is defined as the ratio of blade surface area to total swept area.) A WECS with a high solidity ratio, near $100 \%$, generally has a lower rotational speed than a low solidity rotor of the same diameter.

Blade Materials:

Definition

The blade materials include the skin or surface, the core or body of the blade, and the spar or structural element. This will vary with the type of blade construction. 


\section{Significance}

The importance of blade materials will vary with type of climate and application for which the WECS is intended. Materials descriptions can be used to determine blade life, durability, and maintenance requirements.

System Weight:

Definition

The weight includes all the components of the wind energy conversion system. This includes everything above the top of the tower, and in some cases, components that are part of the tower.

\section{Significance}

This weight will have to be raised to the top of the tower and represents a portion of the static load the tower will experience. In addition, the lower limit of the cost of machinery can be estimated on a price per pound of material basis.

Rotor Weight:

Definition:

The rotor is defined as being the blades (or extractor) and the hub to which it is attached.

\section{Significance}

The weight of the rotor induces additional structural loads on the tower arising from gyroscopic and centrifugal forces. In many cases, the rotor may be hoisted to the top of the tower separately from the rest of the wind machine.

\section{OPERATIONAL CHARACTERISTICS}

Cut-In Wind Speed:

\section{Definition}

The cut-in wind speed is that speed at which the wind machine begins to produce useable output. (This is not the start-up wind speed, which is the speed required to begin rotation of the blades.)

\section{Significance}

In determining the amount of energy a WECS will produce at a specific site, cut-in speed must be known. All winds below that speed are not used in determining energy production. 
Cut-Out Wind Speed:

Definition

This is the wind speed at which the WECS is no longer expected to generate power. It is often referred to as the shut-down wind speed. Method of shut-down is also indicated, i.e. automatic or manual, tail folding, full blade feather, mechanical brake or other.

\section{Significance}

The cut-out wind speed is important because it indicates the wind speed above which no power will be produced by the WECS. Winds above that speed would not be used in determining energy production. Some WECS have automatic means to shut themselves of $f$ whenever winds exceed a pre-set value. Other designs rely on manual intervention in order to avoid operation in dangerously high winds.

Survival Wind Speed:

Definition

This is the maximum wind speed which the WECS is designed to withstand without sustaining structural failure, not necessarily under load. Appropriate safety factors may be stated.

\section{Significance}

The importance of knowing the survival wind speed is apparent. This number should be compared with the maximum winds that are experter at. a glven site over the anticipated service lifc of the WECS. It might be noted that in must cases the system is shutdown and nul pruducing power when exposed lo the survival wind speed.

RPM @ Rated Output

\section{Definition}

The number of complete rotations per minute made by the rotor when the WECS is producing its rated output.

\section{Significance}

This operating rpm is significant primarily in component matching, i.e. in selecting the rotor, drive-train, generator, and other components. 
Maximum RPM @ Wind Speed

Definition

The maximum rpm expected from the rotor and the wind speed at which it occurs.

\section{$\underline{\text { Significance }}$}

This maximum rpm has a direct effect on system loads. Furthermore, it provides an indication of the operating range of the rotor speed controls.

Overspeed Control:

\section{Definition}

Methods used to prevent excessive rotational speeds. Common methods used include: blade feathering, blade stall, mechanical brake, drag brake, lift spoilers, and turning the rotor edgewise to the wind. Operation of overspeed controls may be automatic and/or manual.

\section{Significance}

The overspeed control is, in most cases, also the control that is used to protect the WECS from sustaining structural damage which might result from an ungoverned condition.

\section{Yaw Control:}

\section{Definition}

Yaw control is the means by which the orientation of a horizontal axis WECS is controlled in response to changes in wind direction. A WECS may be free to yaw, damped in yaw, or motor driven in yaw.

\section{Significance}

For horizontal axis WECS, the rate of yaw adjustment is important to their performance. The wind is constantly changing in direction even though it may be from a predominant direction. This will affect power production, but more importantly, it will affect the loads experienced by the rotor due to gyroscopic forces. It should be noted that some horizontal axis and vertical axis WTG's do not need yaw control. 
Generator/A1ternator:

Definition-Description

The description of the generator or alternator includes the type of power generated ( $A C$ or $D C$ ), continuous rated capacity in volts and amps., and a brief description of the source of the field excitation.

\section{Significance}

For a WECS that is used to generate electricity, its generator determines the performance and suitability for a particular application. If the model number is known, performance curves (power vs. rpm, torque vs. rpm, and efficiency vs. rpm) can be obtained from the manufacturer. The nominal and rated voltage and amperage will 1 imit both the power that can be extracted and the lypes of applicaliuls for which a given wind eystem is suited.

Voltage Regulation:

Definition

Voltage regulation is the method, either by electrical, mechanical, or electronic means, that is used to maintain the system output voltage within desired limits.

Significance

There are a number of applicants, battery charging for example, which require voltage control within fairly narrow limits. Other applications, such as line-commutated inverters or resistance healer's do not necessarily requirc voltage control.

Mechanical Power Transmission:

Definition/Description

With some WECS a speed changer is needed to match rotor rpm with the rpm requirements of the generator or other device. Its speed ratio and type is specified. Common types include gear, belt, and hydraulic. Other methods of mechanical power transmissiun are indicated where appropriate.

\section{Significance}

The power transmission affects system life, overall efficiency, and maintenance. Again, specific types of power transmission offer unique characteristics that may make it best suited for a given application. 


\section{PERFORMANCE CHARACTERISTICS}

Rated Power @ Wind Speed:

Definition

This term is the rated power which the wind machine produces and the lowest wind speed at which it occurs. Measured at the output terminals of the generator or the slip rings, this excludes internal power requirements, e.g., the field excitation power.

\section{Significance}

This term is useful in assessing the energy production of a given WECS at a specific site. In general, the lower the rated wind speed, the larger the energy production for an equal rated power.

Maximum Power o Wind Speed:

Definition

The maximum power a WECS will produce and the wind speed at which it occurs.

\section{Significance}

Some WECS have the capability to produce greater amounts of power than the rated value defined above. In some cases these peaks can be maintained for only short periods of time, but in others they can be maintained indefinitely.

\section{Power Curves:}

\section{Definition}

These are graphs of WECS performance, with watts or kilowatts (or other system output) plotted against wind speed. An indication is given, if they are produced by calculalion or by testing. If calculated, the assumed rotor efficiency $(C p)$ is given.

\section{Significance}

These curves are important in that they include all of the subsystem inefficiencies, that is, rotor performance, mechanical power transmission, and generator losses. These curves give a broadly stated indication of how a WECS would perform at a given site. "Although the power in the wind increases with the cube of the velocity, generally the actual performance follows a second order curve. The cut-in, rated and shut-down wind speeds are also indicated on these curves. 
Altitude:

Definition

The total vertical distance from sea level to the center of the rotor's swept area.

\section{Significance}

Power available from the wind is proportional to air density. A WECS whose performance is rated at sea level would provide about 13.8\% less output at 5000 feet of altitude in otherwise identical operating conditions.

Testing Procedures:

\section{Definition}

If the sutpult dat.a were obtained through actual tests, an indication of how the tests were conducted $15 \mathrm{glven}$. This includes a deserip tion of the type and location of wind measuring devices, methods of data collection, and the method of reducing the raw data. Typically the raw data is spread over a range. At a nominal wind speed, a number of power levels could be recorded depending on the rate of wind speed or direction change. The type of load, i.e., batteries, fixed resistance, or variable resistance, is also specified together with other instrumentation used for the test procedure.

\section{Significance}

While power curve for a give WECS may be the most instructive it is, at the same time, the most difficult to obtain. The nature of the wind, the testing methods, and the load all have an impact on wind system performance. In general, a WECS will perform best in a smooth wind flow such as in wind tunnel or "truck" testing (during which the WECS is mounted on a vehicle driven at the desired wind speed). In actual operation, when the wind is constantly changing in direction and speed, performance can be on the order of 25\% less than under ideal conditions. The load also plays an important role because at any given level of power production, there will be an optimum load or power roquirement that maximizes the efficiency of the generator.

Maximum Axial Thrust

Definition

The sum of the horizontal forces on the blades. 


\section{Significance}

Axial thrust is a horizontal force the tower must withstand. This figure can be used to assess tower structural requirements when combined with the gravity load and the air drag on the tower and WECS.

Miscellaneous:

Operation Experience

Length of operation of a wind system that is in or being planned for production and is offered for sale.

Manufacturer's Comments

These describe any design features of a wind system which the manufacturer feels are unique or are of special value to the user.

Warranty

$$
\text { The expressed warranties a manufacturer offers with his system, }
$$
including type of coverage and duration.

\section{Recommended Maintenance}

The manufacturer's recommended schedule of maintenance is specified.

Owner's Manual

An indication is given if an owner's manual is available with or without the purchase of a wind system, along with the cost of the manual. 


\section{CHAPTER THREE:}

WIND MACHINES DATA 
NOTE:

The information contained in this chapter has been supplied by the individual manufacturers or derived from fact sheets or specification sheets distributed by the manufacturers. It should be noted that the information contained here is dependent on the manufacturer's ability to correctly test and evaluate performance, evaluate the maximum power coefficient for a given system design and accurately interpret data for a specific system.

In some cases performance data is based on calculations, while in others the data is derived from experimental testing. It is important that the test conditions be clearly understood, and therefore the manufacturers should be contacted if any questions arise. Users of this guide are encouraged to compare performance data for various systems when selecting one for their particular applications. To assist this evaluation process, TABLE 3.1 lists electrical wind machine output in watts for different rotor diameters at various wind speeds. In calculating the power values shown, a power coefficient, $C p$, of 0.29 was used. TABLE 3.2 provides. a summary of the major characteristics of the mechanical wind machines, arranged according to capacity given a head elevation of approximately 100 feet. 


\section{ELECTRICAL WIND MACHINES}

$-26-$ 
TABLE 3.I

\section{SUMMARY - ELECTRICAL WIND MACHINES}

The following TAELE is a summary of the major characteristics of each electrical wind machine. The data is arranged according to power output.

NAME AND MODEL NUMBER
Energy Development Co. (USA) - 445
Dominion Aluminum Fabricators (Canada)
VAWT $35 \times 55^{\star}$
Grumman Energy Systems
(USA) Windstream 25-B
Energy - Development Co. (USA) - 440
Zephyr Wind Dynamo
15 kVA
Dominion Aluminum Fabricators (Canada)
VAWT $20 \times 30^{\star}$

Millville Windmills (USA) 10-3-IND

SIZE
(rated kW)

45.00

ROTOR DIAMETER
(feet/meters)

$40.0 / 12.2$

37.00

20.000

$36.7 / 11.2$

$25.0 / 7.62$

20.00

$38.0 / 11.6$

15.000

14.000

$20.0 / 6.10$

$20.0 / 6.10$

10.00

$25.0 / 7.60$

Wind Power Systems, Inc. (USA)

Storm Master 10 (Prototype)

Aerowatt S.A. (France) 4100FP7G

Dakota Wind \& Sun, Ltd. $4 \mathrm{kw}$

Dynergy - 5 Meter*

6.000

$32.8 / 10.0$

4. 100

$32.7 / 9.30$

4.000

$14.0 / 4.3$

3.300

$15.0 / 4.6$

Product Development Institute (USA)

Wind Heat System (Prototype)

3.000

$13.6 / 4.15$

3.000

$12.5 / 3.8$

NO. ELADES
4
2
(Darrieus)

3

4

3

$\stackrel{2}{2}$

3

3

2

3

$$
2
$$

(Darrieus)

\begin{tabular}{l}
$\begin{array}{l}\text { RATED SPEED } \\
\text { MPH/ } \mathrm{m} / \mathrm{s}\end{array}$ \\
\hline $25 / 11.2$ \\
$33 / 14.8$
\end{tabular}

29/12. 9

25/11.2

$30 / 13.4$

$30 / 13.5$

$25 / 11.0$

$18 / 8.0$

$16 / 7.2$

$27 / 12.0$

$24 / 10.7$

$27 / 12.0$

$25 / 11.1$
CUT-IN SPEED $\mathrm{MPH} / \mathrm{m} / \mathrm{s}$

$5 / 2.2$

$13 / 5.8$

$8 / 3.6$

$5 / 2.2$

$8 / 3.6$

$12 / 5.4$

$9 / 4.0$

$8 / 3.6$

$7 / 3.1$

$8 / 3.6$

$10 / 4.4$

$12 / 5.4$

$12 / 5.4$ Wind Jennie (Prototype)

*Vertical axis 
TABLE 3.1 - Summary - Electrical Wind Machines (Continued)

\begin{tabular}{|c|c|c|c|c|c|}
\hline NAME AND MODEL NUMBER & $\begin{array}{c}\text { SIZE } \\
\text { (rated kW) }\end{array}$ & $\begin{array}{l}\text { ROTOR DIAMETER } \\
\text { (feet/meters) }\end{array}$ & NO. BLADES & $\begin{array}{l}\text { RATED SPEED } \\
\mathrm{MPH} / \mathrm{m} / \mathrm{s} \\
\end{array}$ & $\begin{array}{l}\text { CUT-IN SPEED } \\
\mathrm{MPH} / \mathrm{m} / \mathrm{s}\end{array}$ \\
\hline Kedco, Inc. (USA) 1620 & 3.000 & $16.0 / 4.88$ & 3 & $25 i 11.1$ & $11 / 4.9$ \\
\hline $\begin{array}{l}\text { North Wind Power Company (USA) Eagle } \\
3 \mathrm{kw}-32 \mathrm{~V}\end{array}$ & 3.000 & $13.6 / 4.14$ & 3 & $27 ; 12.2$ & $8 / 3.6$ \\
\hline $\begin{array}{l}\text { North Wind Power Company (USA) Eagle } \\
3 \mathrm{kw}-110 \mathrm{~V}\end{array}$ & 3.000 & $13.6 / 4.14$ & 3 & $27 ! 12.2$ & $8 / 3.6$ \\
\hline $\begin{array}{l}\text { Altos, The Alternate Curment (USA) } \\
\text { BWP-12A }\end{array}$ & 2.200 & 8. $0 / 2.4$ & 24 & $38 / 17.1$ & $8 / 3.6$ \\
\hline $\begin{array}{l}\text { Pinson Energy Corporation (USA) } \\
\mathrm{C}-2 \mathrm{E} \text { (Prototype) }{ }^{\star}\end{array}$ & 2.000 & $12.0 / 3.66$ & 3 & $24 / 10.7$ & $7 / 3.1$ \\
\hline Altos, The Alternate Current BWP-12B & 2.000 & $11.5 / 3.5$ & N.A. & $28 / 12.5$ & $8 / 3.6$ \\
\hline $\begin{array}{l}\text { American Wind Turbine, Inc. (USA). } \\
16 \text { foot }\end{array}$ & 2.000 & $15.3 / 4.7$ & 48 & $20 / 9.0$ & $10 / 4.5$ \\
\hline $\begin{array}{l}\text { Dunlite Electrical Products (Australia) } \\
81 / 002550 \text { (Standard Model) }\end{array}$ & 2.000 & $13.5 / 4.10$ & 3 & $25 / 11.0$ & $8 / 3.6$ \\
\hline Kedco, Inc. (USA) 1210 & 2.000 & $12.0 / 3.65$ & 3 & $26 / 11.6$ & $11 / 4.9$ \\
\hline redco, Inc. (USA) 1610 & 2.000 & $16.0 / 4.88$ & 3 & $2 ? / 10.0$ & $10 / 4.4$ \\
\hline $\begin{array}{l}\text { North Wind Power Compary (USA) Eagle } \\
2 \mathrm{kw}-32 \mathrm{~V}\end{array}$ & 2.000 & $13.6 / 4.15$ & 3 & $22 / 10.0$ & $8 / 3.6$ \\
\hline $\begin{array}{l}\text { North Wind Power Company (USA) Eagle } \\
2 \mathrm{kw}-110 \mathrm{~V}\end{array}$ & 2.000 & $13.6 / 4.2$ & 3 & $22 / 10.0$ & $8 / 3.6$ \\
\hline Whirlwind Power Company (USA) Model A & 2.000 & $10 / 3.0$ & 2 & $25 / 11.2$ & $8 / 3.6$ \\
\hline Kedco, Inc. (USA) 1605 & 1.900 & $16.0 / 4.88$ & 3 & $20 / 8.9$ & $7 / 3.1$ \\
\hline Enertech Corp. (USA) 1500 & 1.500 & $13.2 / 4$ & 3 & $22 / 9.8$ & $8 / 3.6$ \\
\hline
\end{tabular}

*Vertical axis 
TABLE 3.1 - Summary - Electrical Wind Machines (Continued)

\begin{tabular}{|c|c|c|c|c|c|}
\hline NAME AND MODEL NUMBER & $\begin{array}{c}\text { SIZE } \\
\text { (rated kw) } \\
\end{array}$ & $\begin{array}{l}\text { ROTOR DIAMETER } \\
\text { (feet/meters) }\end{array}$ & NO. BLADES & $\begin{array}{l}\text { RATED SPEED } \\
\mathrm{MPH} / \mathrm{m} / \mathrm{s} \\
\end{array}$ & $\begin{array}{l}\text { CUT-IN SPEED } \\
\mathrm{MPH} / \mathrm{m} / \mathrm{s}\end{array}$ \\
\hline $\begin{array}{l}\text { Altos, The Alternate Current (USA) } \\
\text { BWP-8A }\end{array}$ & 1.500 & $8.0 / 2.4$ & 24 & $28 / 12.5$ & $8 / 3.6$ \\
\hline Aero Power Systems, Inc. (USA) SL150D & 1.430 & $10.0 / 3.05$ & 3 & $25 / 11.2$ & $6 / 2.7$ \\
\hline Kedco, Inc. (USA) 1200 & 1.200 & $12.0 / 3.65$ & 3 & $22 / 10.0$ & $7 / 3.1$ \\
\hline Kedco, Inc. (USA) 1205 & 1.200 & $12.0 / 3.65$ & 3 & $22 / 10.0$ & $8 / 3.6$ \\
\hline Kedco, Inc. (USA) 1600 & 1.200 & $16.0 / 4.88$ & 3 & $17 / 7.6$ & $7 / 3.1$ \\
\hline Aerawatt S.A. (France) 1100PF7G & 1.125 & $16.7 / 5.09$ & 2 & $16 / 7.2$ & $7 / 3.1$ \\
\hline $\begin{array}{l}\text { American Wind Turbine, Inc. (USA) } \\
12 \text { Foot }\end{array}$ & 1.000 & $11.5 / 3.5$ & 36 & $20 / 9.0$ & $10 / 4.5$ \\
\hline $\begin{array}{l}\text { Dunlite Electrical Products (Australia) } \\
82 / 002550 \text { (High Wind Speed Model) }\end{array}$ & 1.00 & $10.0 / 3.1$ & 3 & $37 / 16 / 5$ & $14 / 6.3$ \\
\hline Sencenbaugh Wind Electric (USA) 1000 & 1.000 & $12.0 / 3.65$ & 3 & $23 / 10.3$ & $6 / 2.7$ \\
\hline $\begin{array}{l}\text { Aerolectric Company (USA) C-9/C-90 } \\
\text { Wind Wizard }\end{array}$ & 0.600 & $9.0 / 2.75$ & 3 & $26 / 11.6$ & $9 / 4.0$ \\
\hline $\begin{array}{l}\text { American Wind Turbine, Inc. (USA) } \\
8 \text { foot }\end{array}$ & .500 & $7.6 / 2.3$ & 24 & $20 / 9.0$ & $10 / 4.5$ \\
\hline Sencenbaugh Wind Electric (USA) 500 & .500 & $6.0 / 1.8$ & 3 & $24 / 10.8$ & $10 / 4.5$ \\
\hline $\begin{array}{l}\text { Sencenbaugh Wind Electric (USA) } \\
400-14 \text { HDS }\end{array}$ & .400 & $7.0 / 2.13$ & 3 & $20 / 9.0$ & $9 / 4.0$ \\
\hline Aerowatt S.A. (France) 300FP7G & 0.350 & $10.7 / 3.26$ & 2 & $16 / 7.2$ & $7 / 3.1$ \\
\hline $\begin{array}{l}\text { Winco - Division of Dynatechnology } \\
\text { (USA) } 1222 \mathrm{H}\end{array}$ & 0.200 & $6.0 / 1.83$ & 2 & $23 / 10.3$ & $7 / 3.1$ \\
\hline
\end{tabular}


TABLE 3.1 - Summary - Electrical Wind Machines (Continued)

NAME AND MODEL NUMBER

Aerowatt S.A. (France) 150FP7G

Aerowatt S.A. (France) 24:P7i

Zephyr Wind Dynamo Tetrahelix $S$

$\begin{array}{ccc}\begin{array}{c}\text { SIZE } \\ \text { (rated kW) }\end{array} & & \begin{array}{c}\text { ROTOR DIAMETER } \\ \text { (feet/meters) }\end{array} \\ 0.130 & & 6.7 / 2.04 \\ 0.028 & & 3.3 / 1.00 \\ .00 \pi & & 2.0 / .61\end{array}$

NO. BLADES
2
2
2

RATED SPEED

$\mathrm{MPH} / \mathrm{m} / \mathrm{s}$

$16 / 7.2$

$16 / 7.2$

$25 / 11.2$
CUT-IN SPEED $\mathrm{MPH} / \mathrm{m} / \mathrm{s}$

$7 / 3.1$

$7 / 3.1$

$12 / 5.4$ 


\section{ELECTRICAL WIND MACHINE DATA SHEETS}

(The data sheets are arranged alphabetically by manufacturer.) 


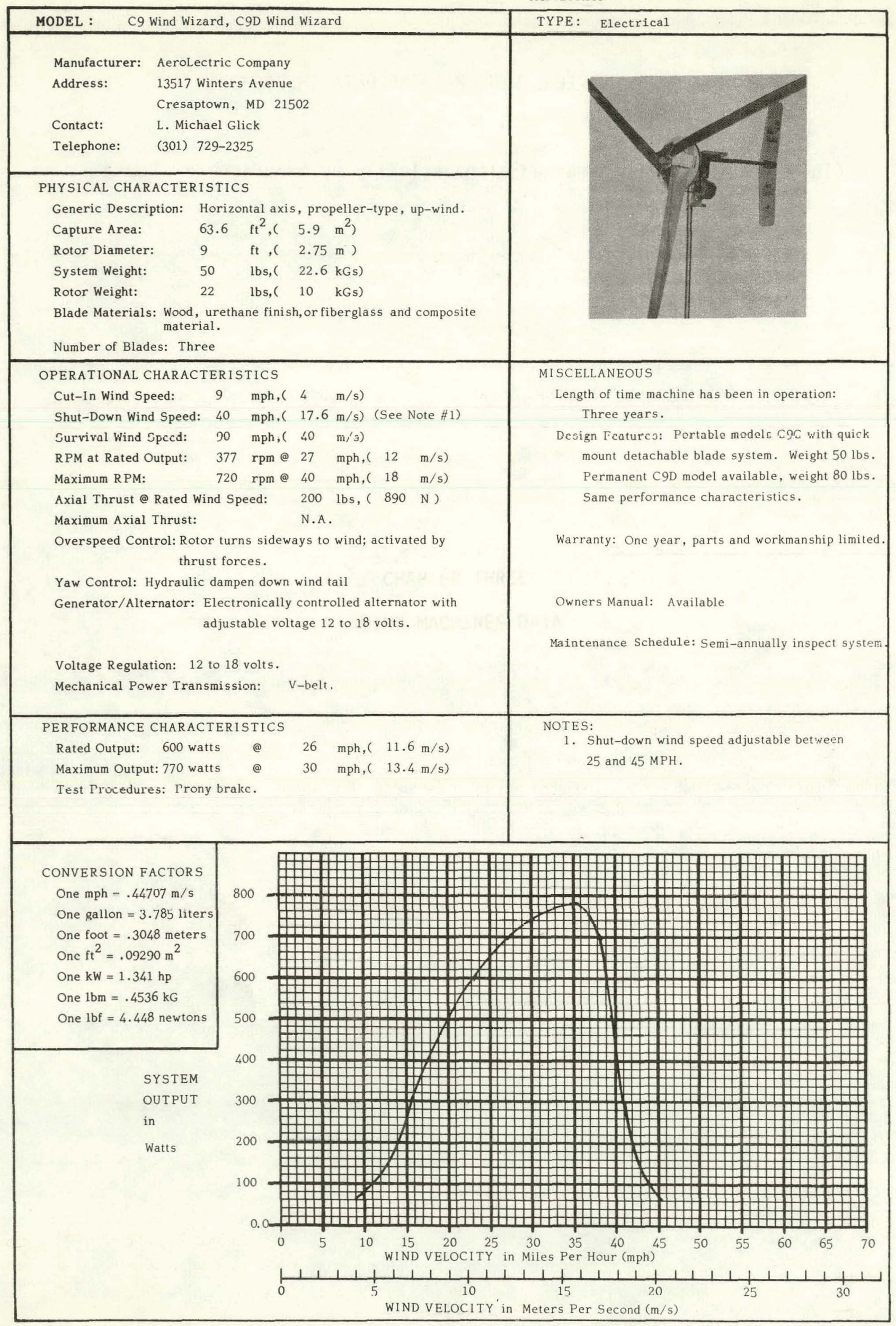


MODEL : SL 1500

Manufacturer: Aero Power Systems, Inc.

Address: 2398 Fourth Street

Berkeley, CA 97410

Contact:

Mario V. Agnello

Telephone:

(415) $848-2710$

PHYSICAL CHARACTERISTICS

Generic Description: Horizontal axis, propeller-type, up-wind.

Capture Area: $\quad 78.5 \mathrm{ft}^{2},\left(7.3 \mathrm{~m}^{2}\right)$

Rotor Diameter: $\quad 10 \mathrm{ft},(3.05 \mathrm{~m}$ )

System Weight: $\quad 160 \mathrm{lbs},(\quad 72.6 \mathrm{kGs})$

Rotor Weight:

$50 \mathrm{lbs},(22.7 \mathrm{kGs})$

Blade Materials: Wood, sitka spruce.

Exterior is painted with acrylic enamel.

Leading edge covered with stainless steel tape.

OPERATIONAL CHARACTERISTICS

Cut-In Wind Speed: $6 \mathrm{mph},(2.7 \mathrm{~m} / \mathrm{s})$

Shut-Down Wind Speed: $100 \mathrm{mph},(44.7 \mathrm{~m} / \mathrm{s})$

Survival Wind Speed: $100 \mathrm{mph},(44.7 \mathrm{~m} / \mathrm{s})$

RPM at Rated Output: $\quad 500 \mathrm{rpm} @ 20 \mathrm{mph},(\quad 8.9 \mathrm{~m} / \mathrm{s})$

Maximum RPM: $\quad 650 \mathrm{rpm} @ 25 \mathrm{mph},(11.2 \mathrm{~m} / \mathrm{s})$

Axial Thrust @ Rated Wind Speed: $300 \mathrm{lbs},(1334 \mathrm{~N})$

Maximum Axial Thrust: N.A. lbs, ( N )

Overspeed Control: Mechanical, variable pitch, centrifugally activated,

Yaw Control: None, rotor aligned with wind by tail.

Generator/Alternator: 14 or 28 VAC, 3 phase, rectified for DC output.

Voltage Regulation: Availahle: (standard)

Mechanical Power Transmission: Gear box, ratio $=3: 1$

PERFORMANCE CHARACTERISTICS

Rated Output: $\quad 1.43 \mathrm{~kW} @ 25 \mathrm{mph},(11.2 \mathrm{~m} / \mathrm{s})$

Maximum Output: $\quad 1.60 \mathrm{~kW} @ 30 \mathrm{mph},(13.4 \mathrm{~m} / \mathrm{s})$

Test Procedures: Operation in field.

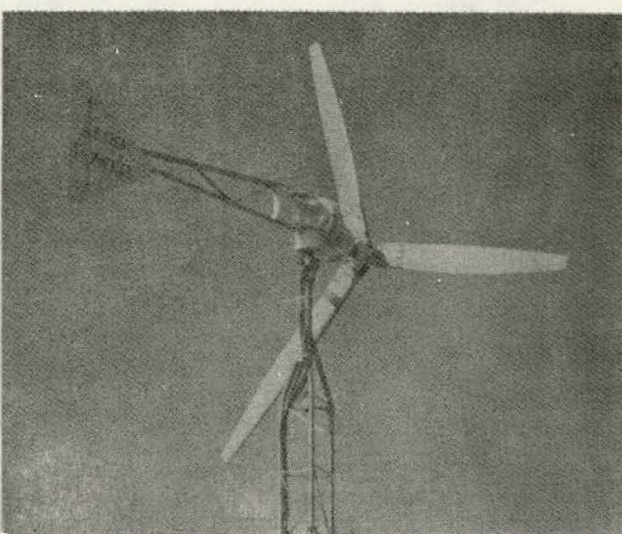

MISCELLANEOUS

Length of time machine has been in operation:

Design Features:

Modified Clark Y airfoil.

Warranty: Defects in workmanship \&/or materials are covered for one year from the purchase date. Parts must be returned to an authorized Aero Power repair location for repair or replacement.

Owners Manual: Available, (standard).

Includes assembly, wiring and maintenence.

Maintenance Schedule: Semi-annually, grease hub. Check blades for nicks and scratches.

Inspect entire system.

Batteries, if used, should recieve an equalizing charge at least every two months.

NOTES:

Initial sales of this system are scheduled for August , 1978
CONVERSION FACTORS

One $\mathrm{mph}=.44707 \mathrm{~m} / \mathrm{s}$

One gallon $=3.785$ liters

One foot $=.3048$ meters

One $\mathrm{ft}^{2}=.09290 \mathrm{~m}^{2}$

One $\mathrm{kW}=1.341 \mathrm{hp}$

One $\mathrm{lbm}=.4536 \mathrm{kG}$

One $\mathrm{lbf}=4.448$ newtons

SYSTEM

OUTPUT

in

Kilowatts

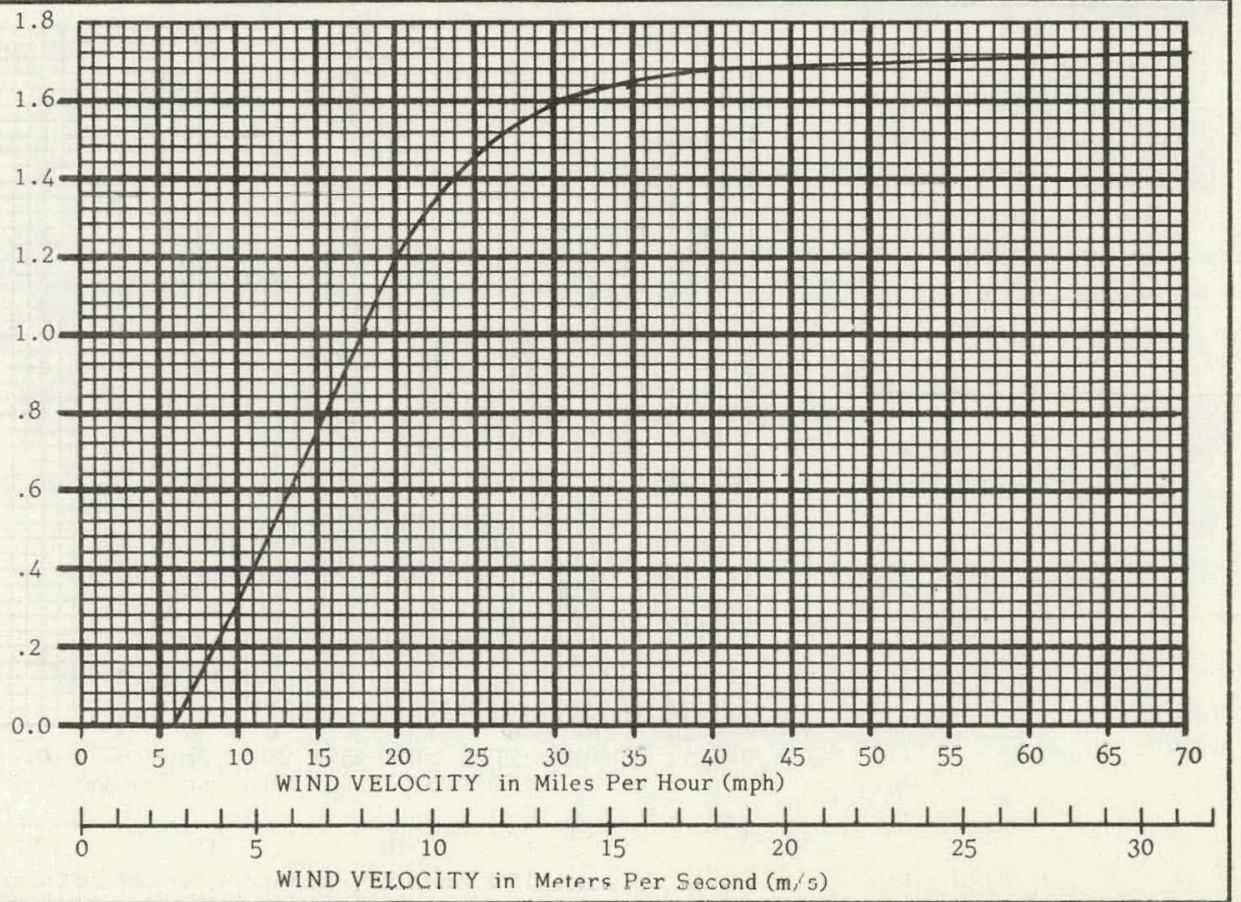


Aerowall S. A.

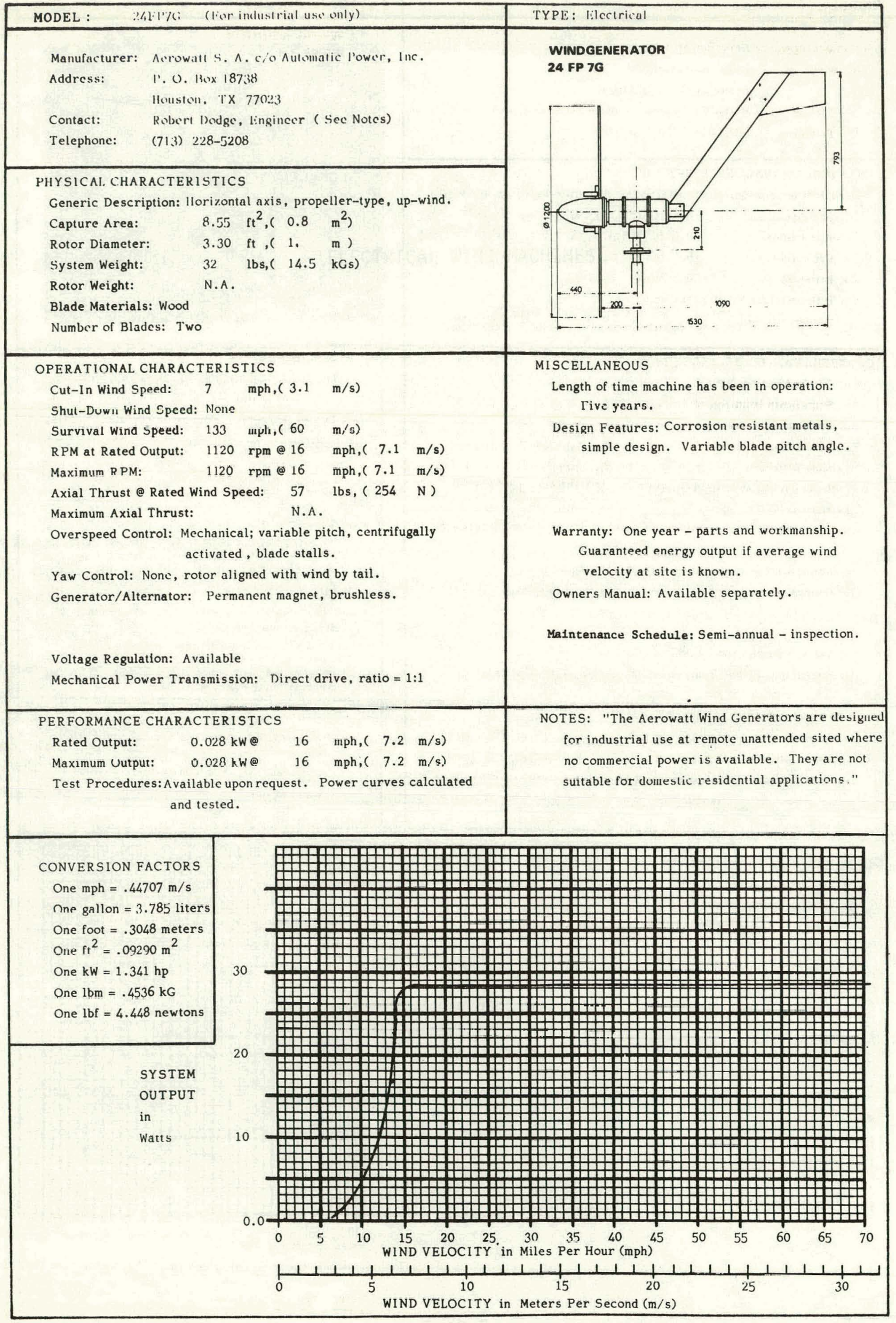


Acrowall S.A.

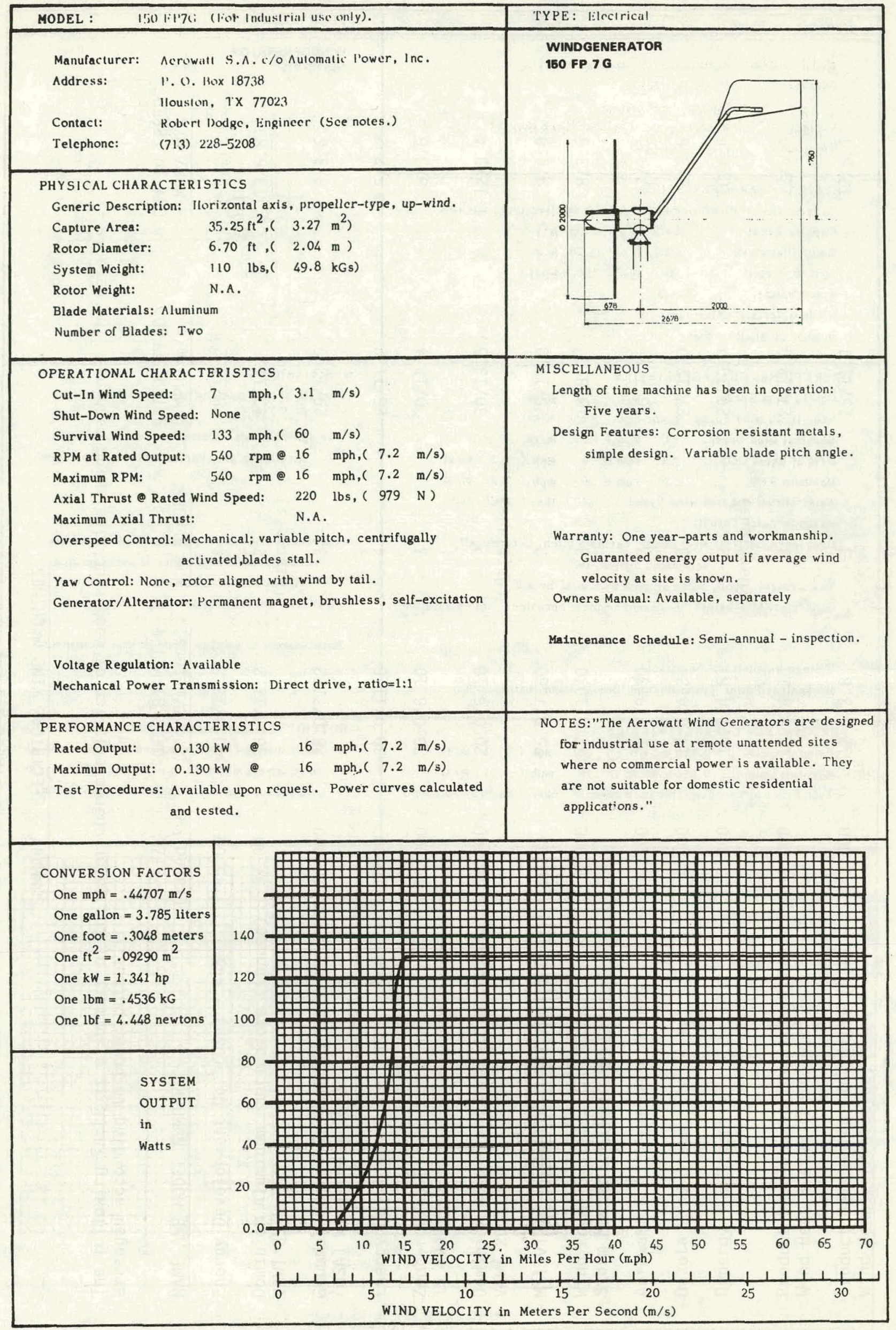


Arrowall Si. A.

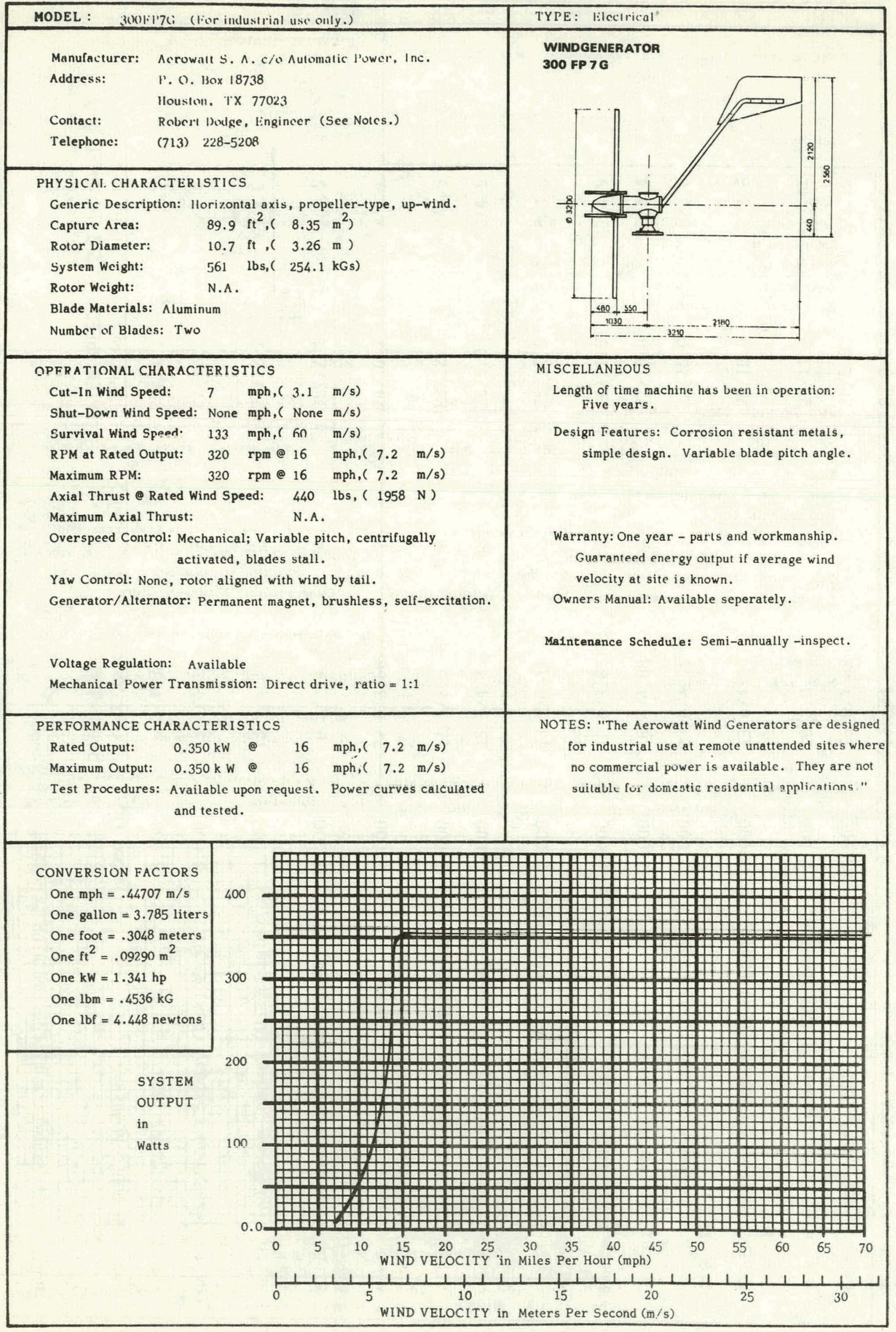


A n rowatl S. A.

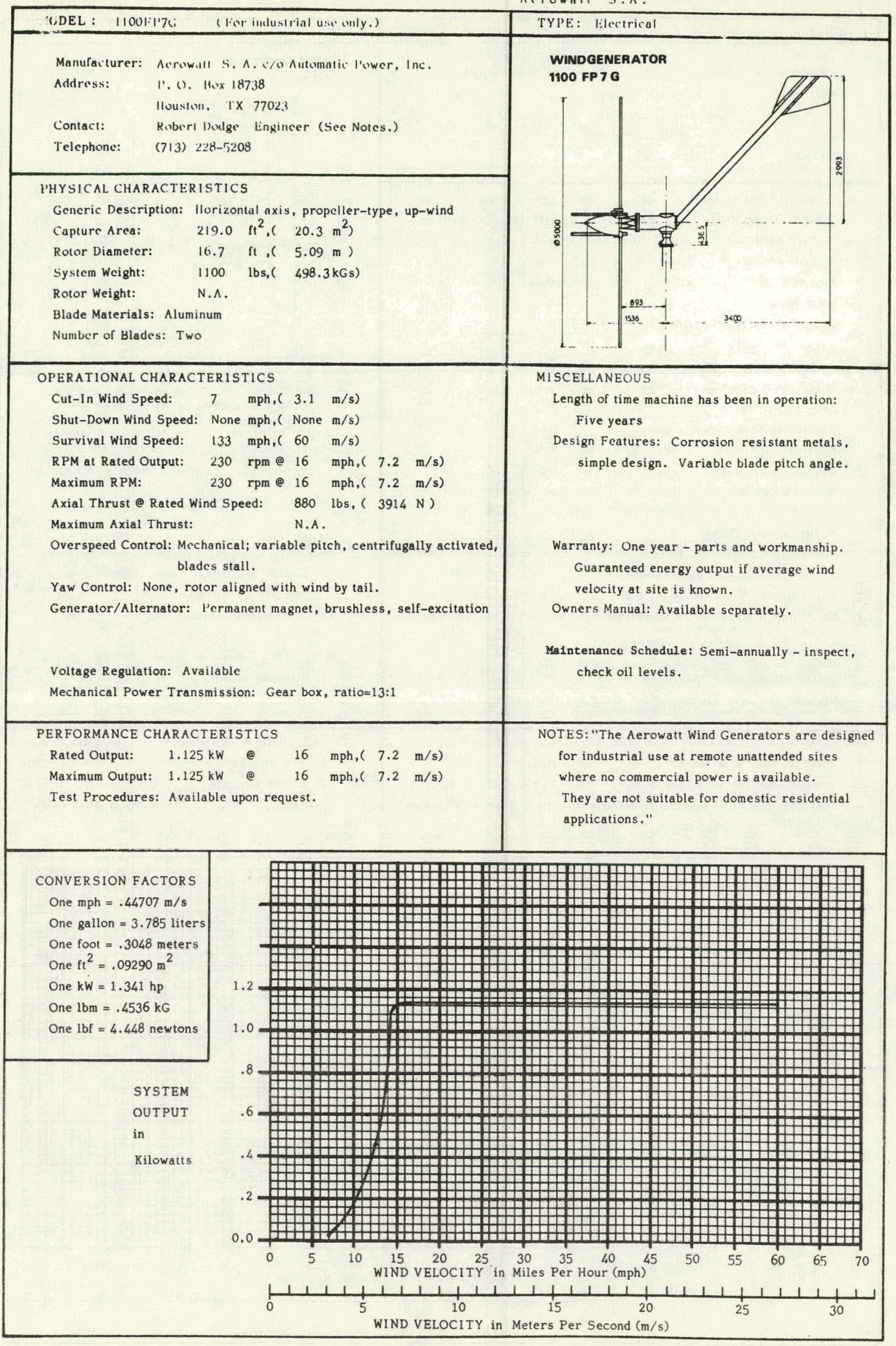


Aorowall Si.

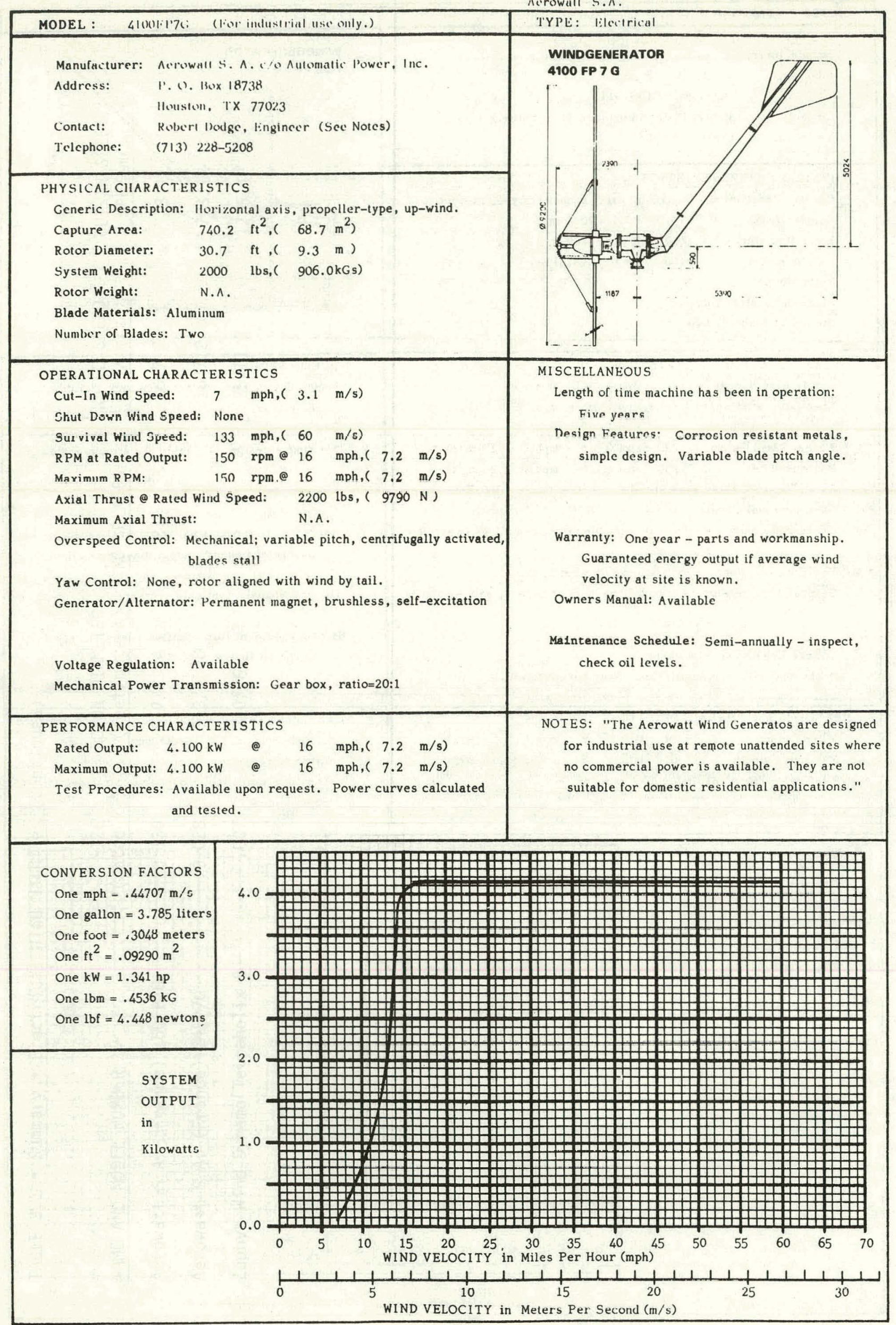




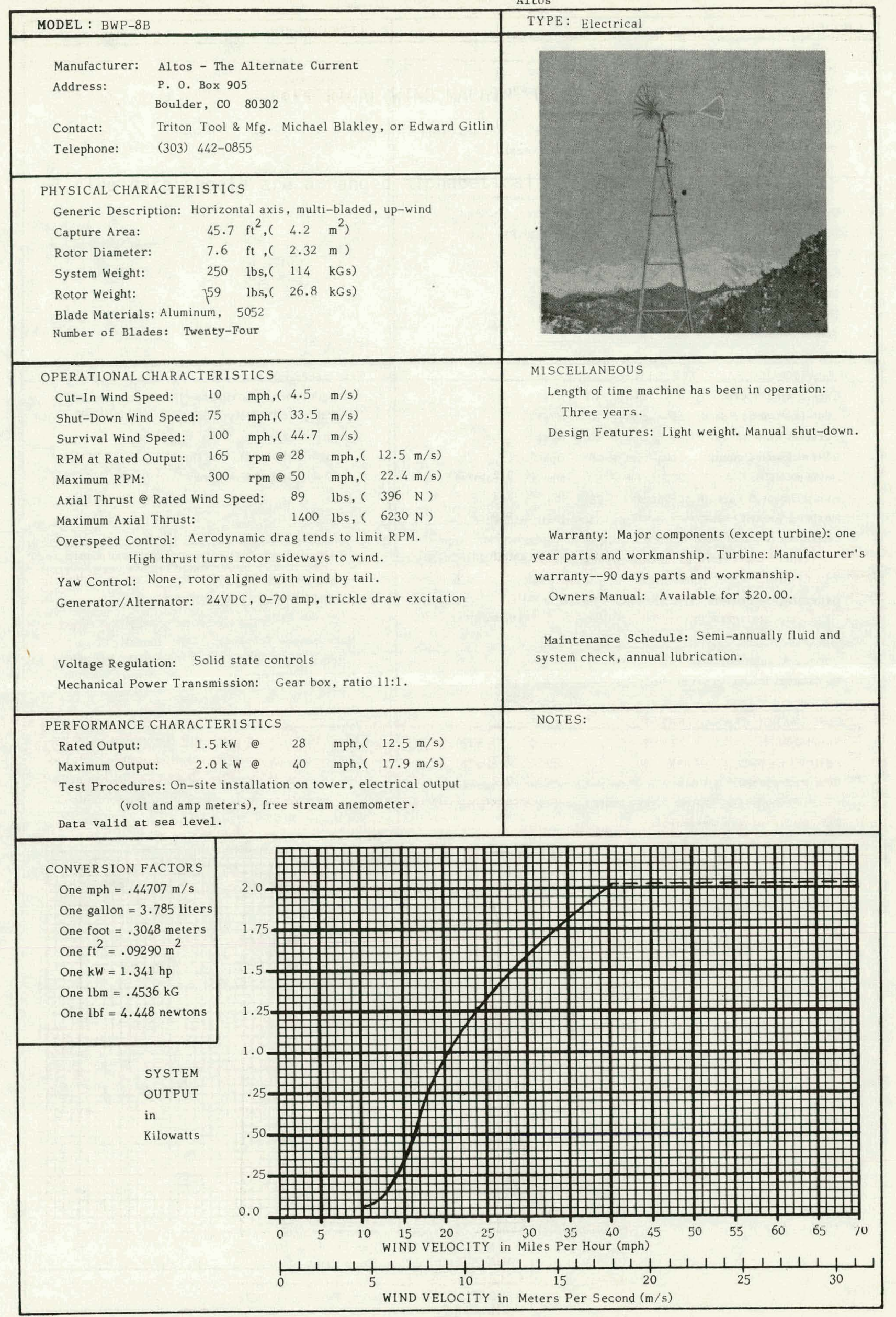


A1tos

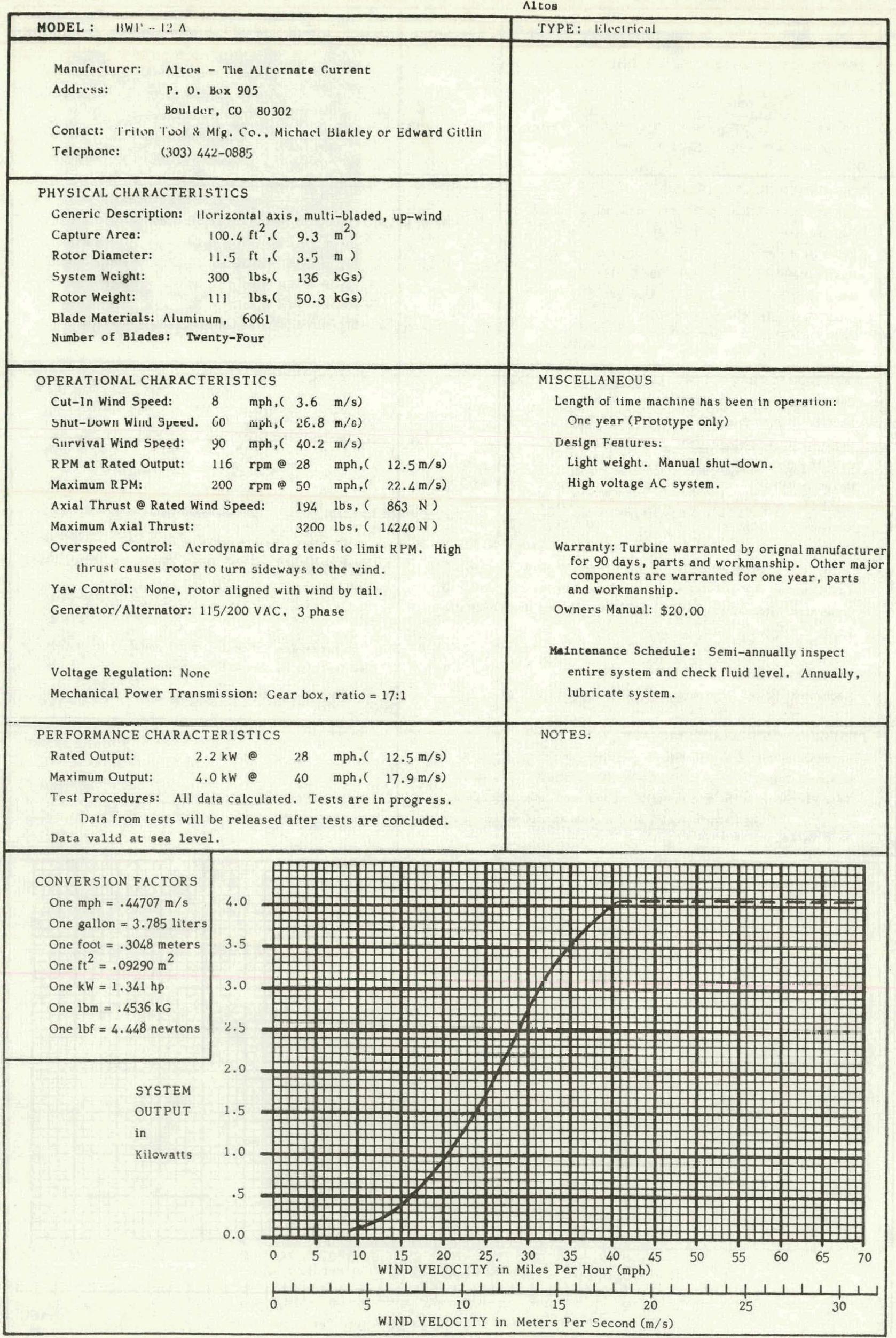




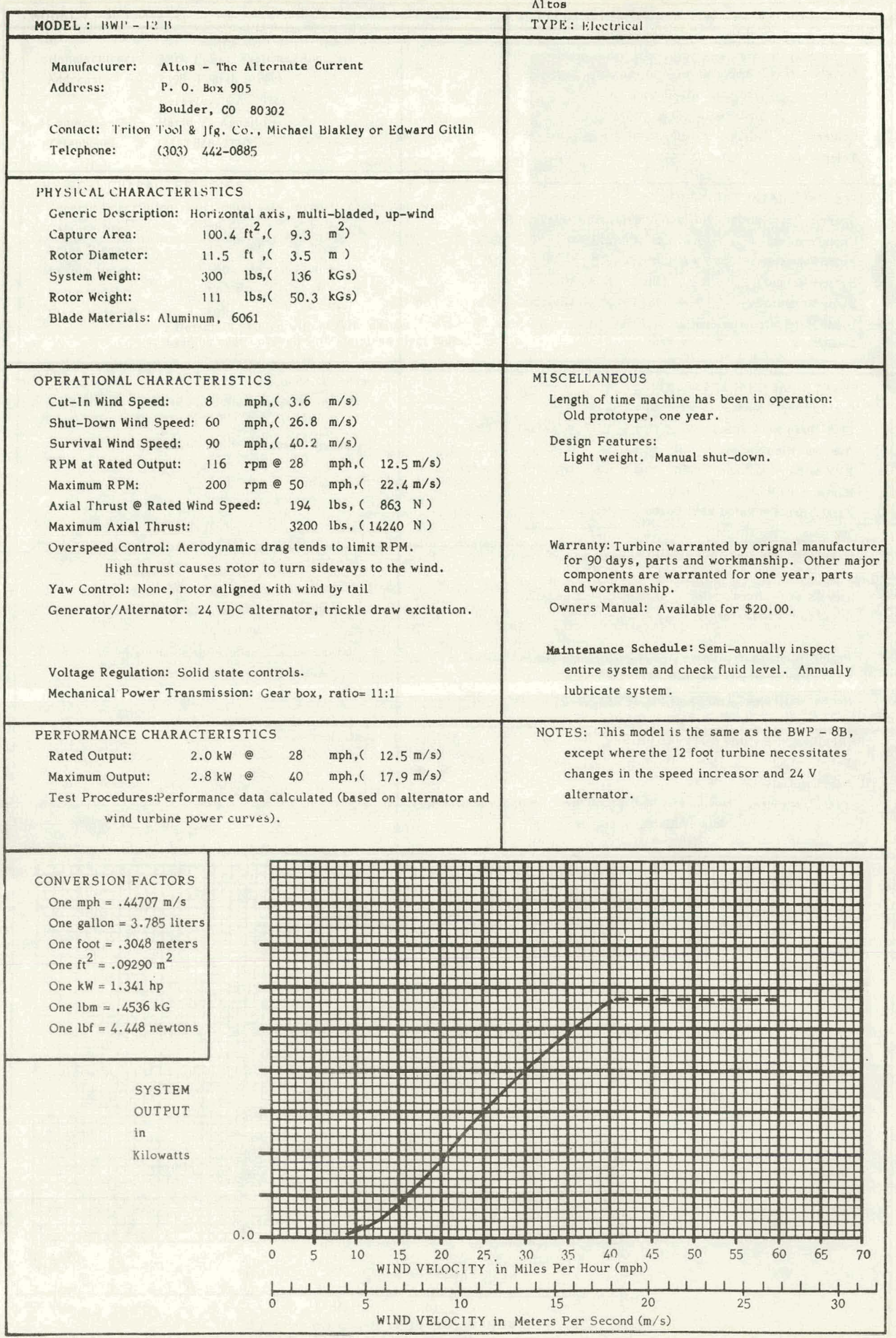


American Wind Turbine

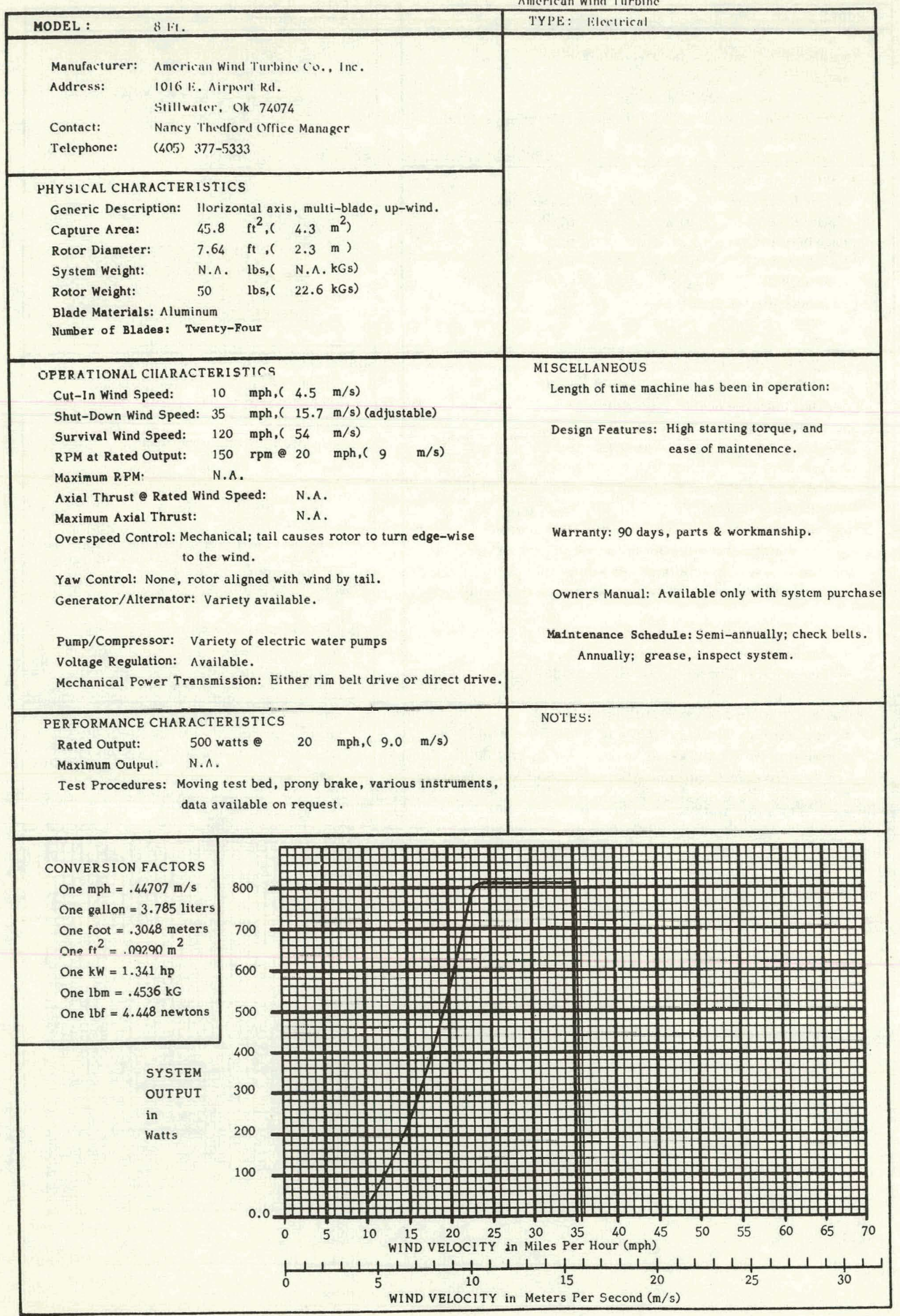




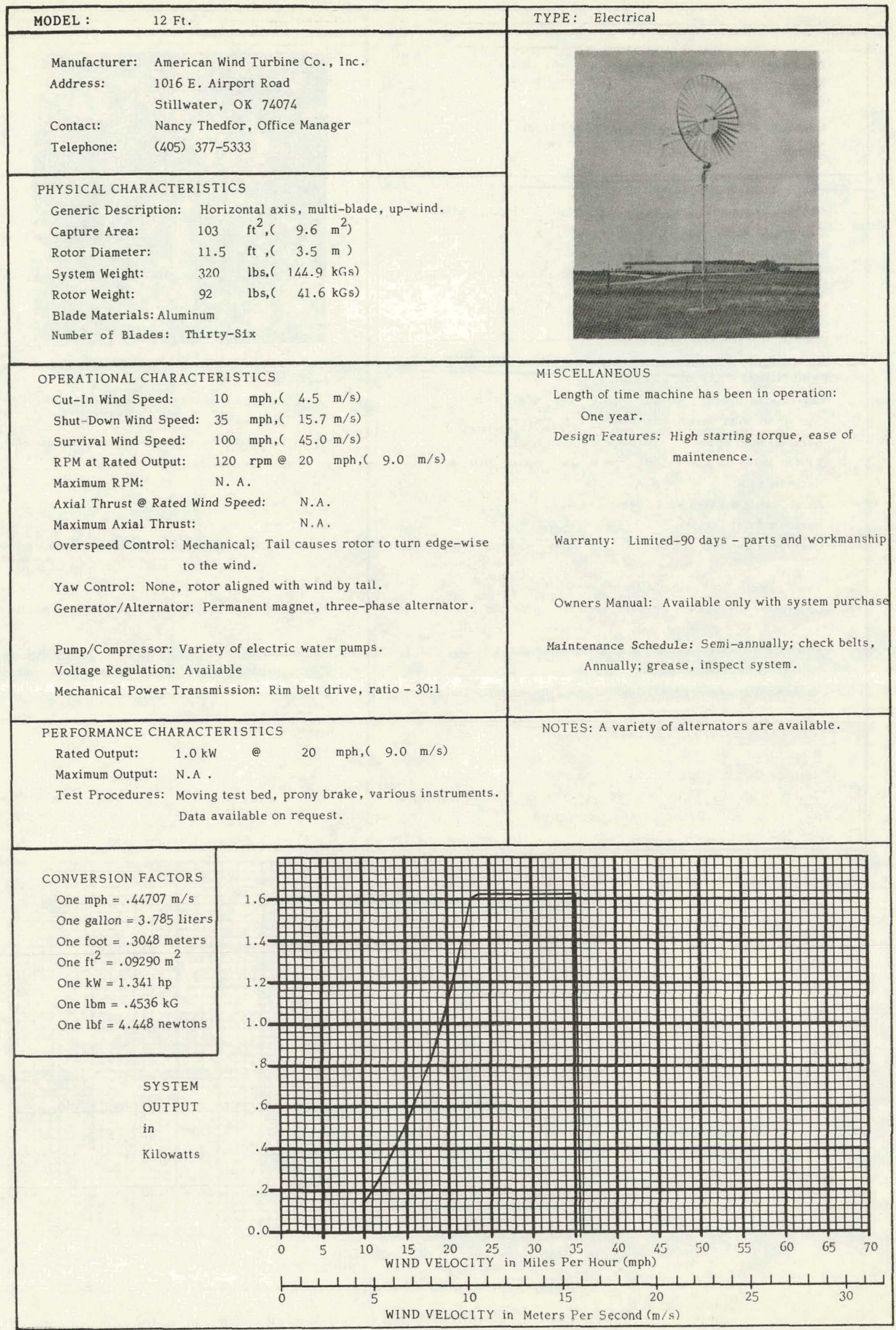




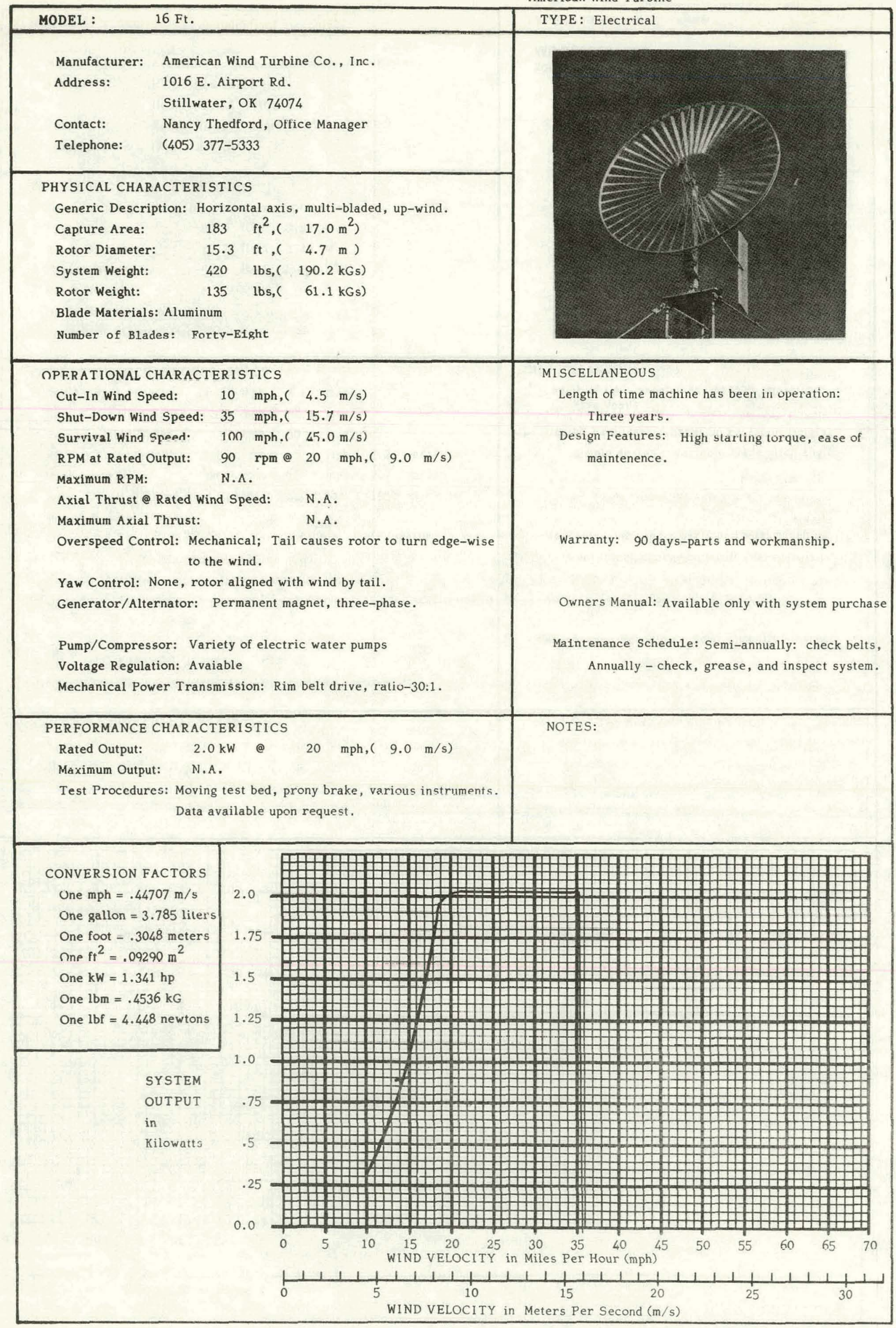




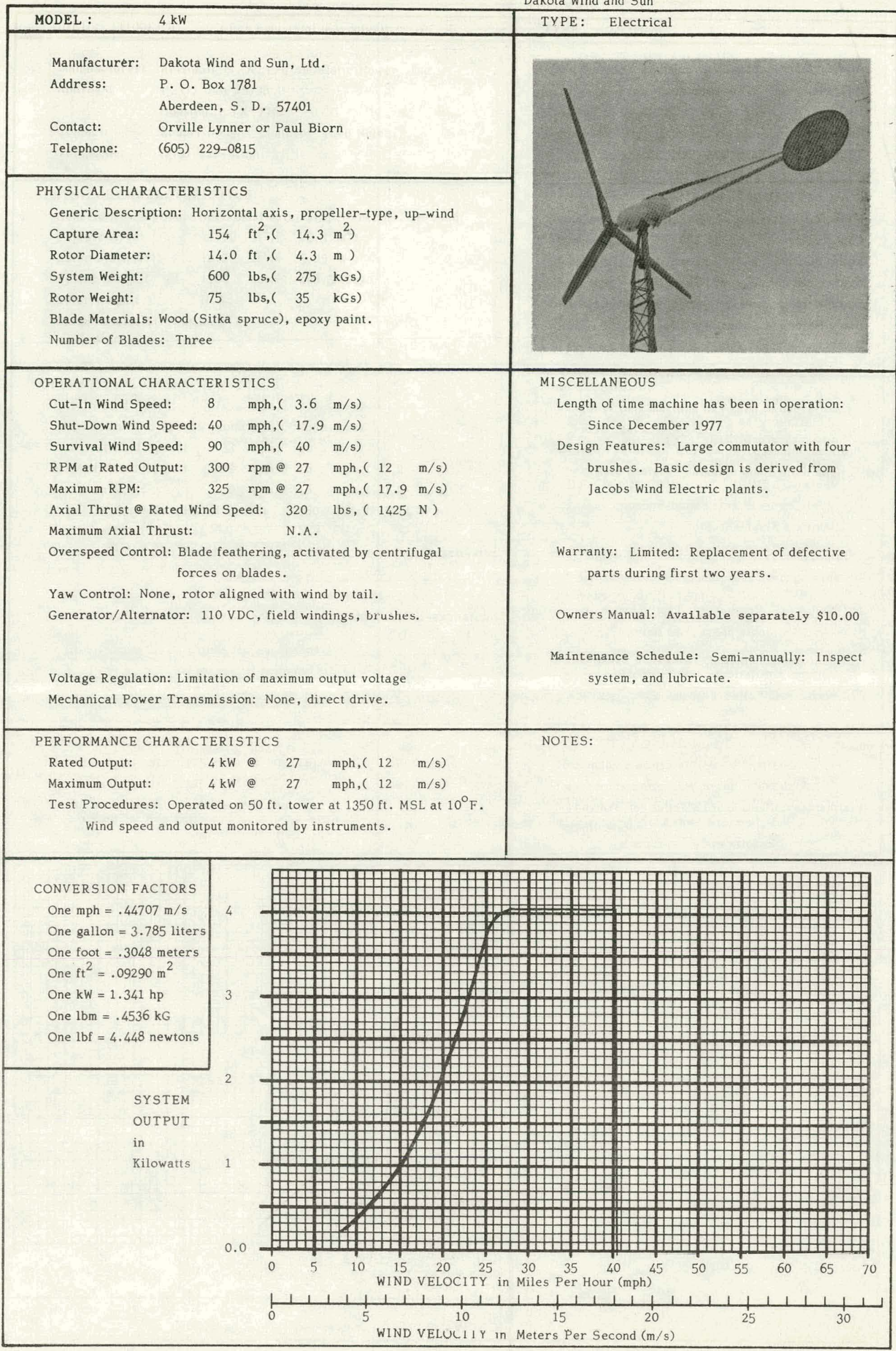




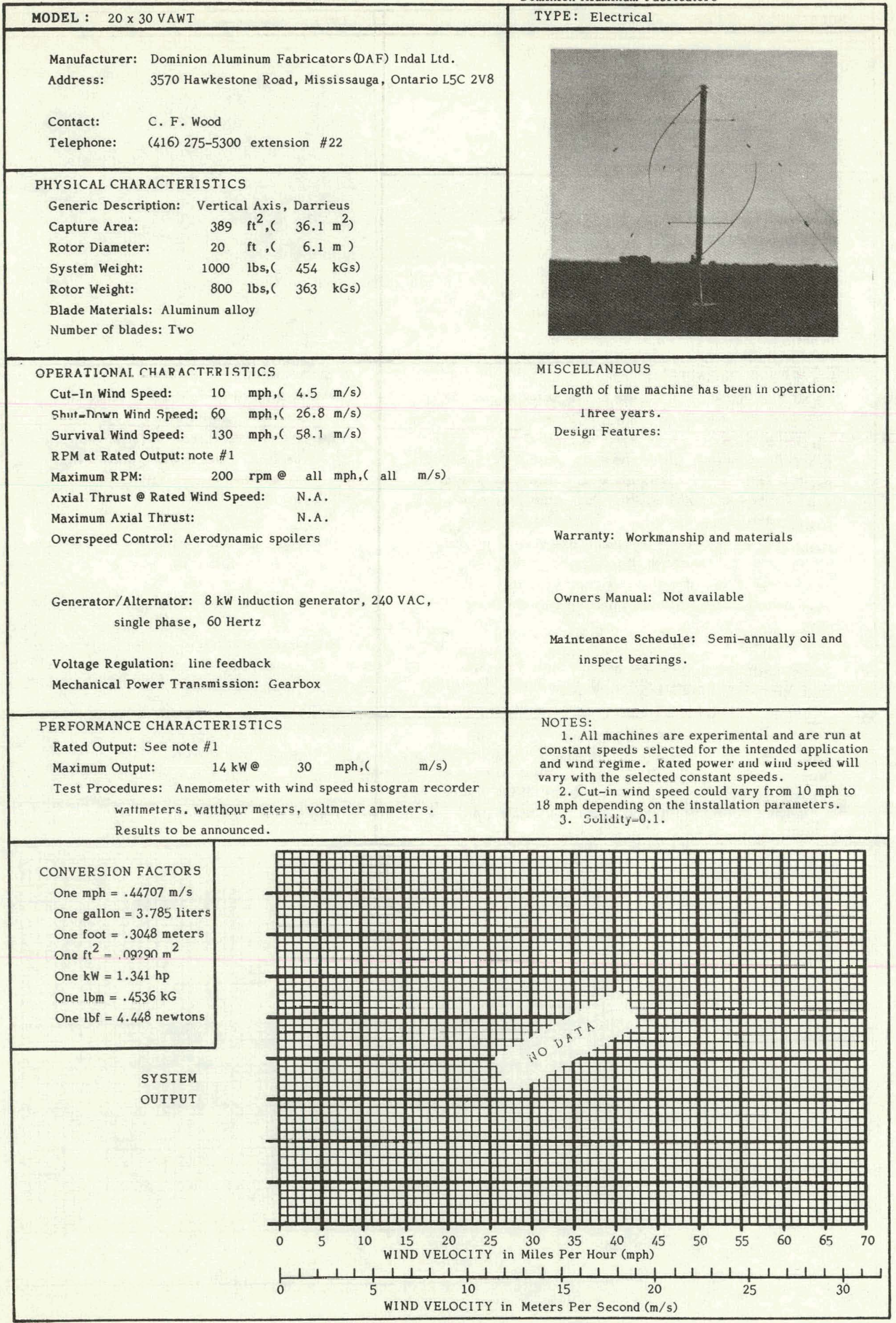




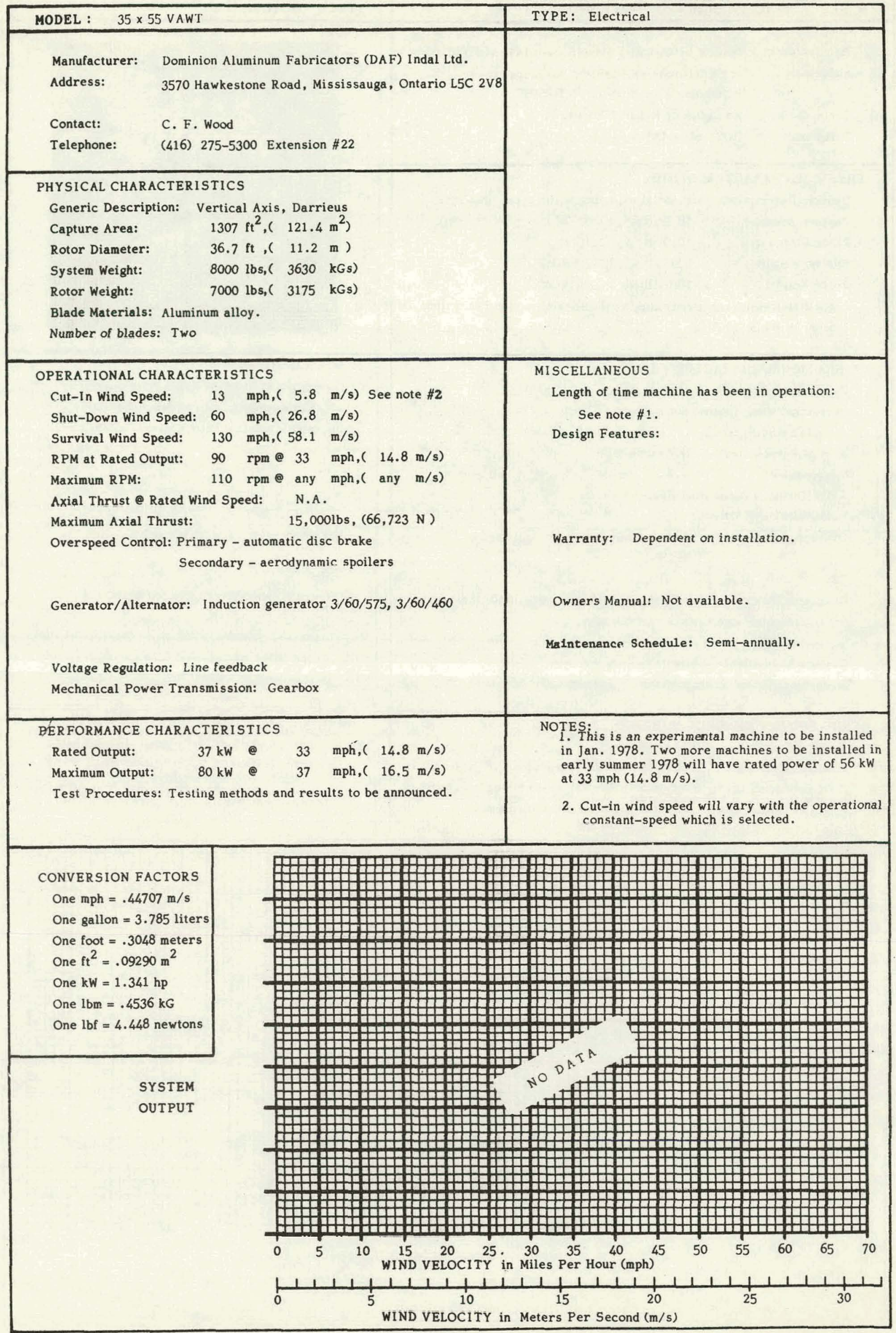




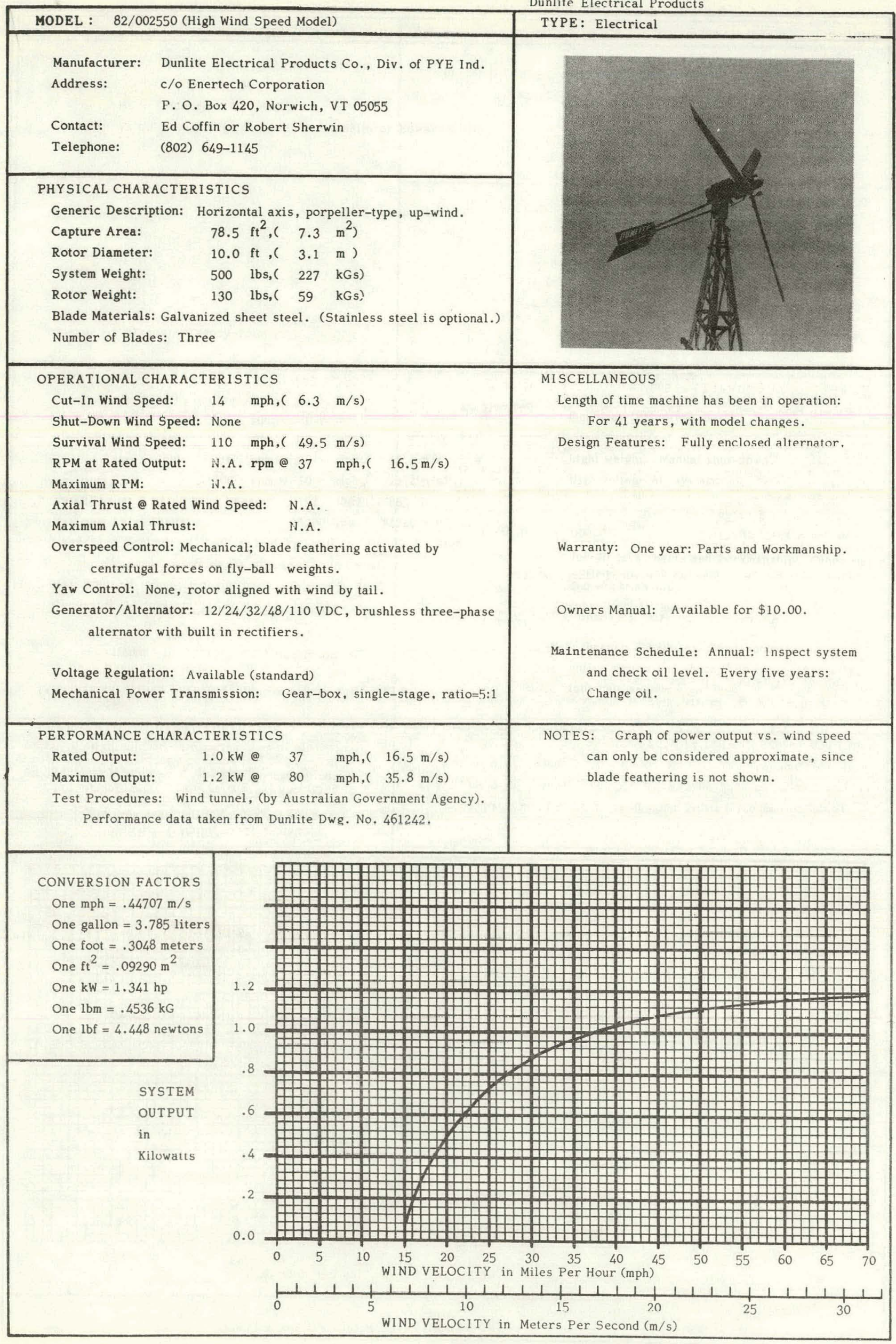


Manufacturer: Dunlite Electrical Products Co., Div. of PYE Ind.

Address: c/o Enertech Corporation

P. O. Box 420, Norwich, VT 05055

Contact: Ed Coffin or Robert Sherwin

Telephone: (802) 649-1145

PHYSICAL CHARACTERISTICS

Generic Description: Horizontal axis, propeller-type, up-wind.

Capture Area: $\quad 143.1 \mathrm{ft}^{2},\left(13.3 \mathrm{~m}^{2}\right)$

Rotor Diameter: $\quad 13.5 \mathrm{ft},(4.1 \mathrm{~m})$

System Weight: $\quad 500$ lbs, ( 227 kGs)

Rotor Weight: $\quad 130$ lbs, ( 59 kGs)

Blade Materials: Galvanized sheet steel. (Stainless steel is optional.)

Number of blades: Three

OPERATIONAL CHARACTERISTICS

Cut-In Wind Speed: $8 \mathrm{mph},(3.6 \mathrm{~m} / \mathrm{s})$

Shut-Down Wind Speed: None

Survival Wind Speed: $80 \mathrm{mph},(36 \mathrm{~m} / \mathrm{s})$

RPM at Rated Output: $185 \mathrm{rpm} @ 25 \mathrm{mph},(\quad 11 \mathrm{~m} / \mathrm{s})$

Maximum RPM: $\quad 200 \mathrm{rpm} @ 35 \mathrm{mph},(15.6 \mathrm{~m} / \mathrm{s})$

Axial Thrust@ Rated Wind Speed: N.A.

Maximum Axial Thrust: N.A.

Overspeed Control: Mechanical; blade feathering activated by centrifugal forces on fly-balls.

Yaw Control: None, rotor aligned with wind by tail.

Generator/Alternator: 12/24/32/48/110 VDC, brushless three-phase alternator with built-in rertifiers.

Voltage Regulation: Standard

Mechanical Power Transmission: Gear box, single stage, ratio $=5: 1$

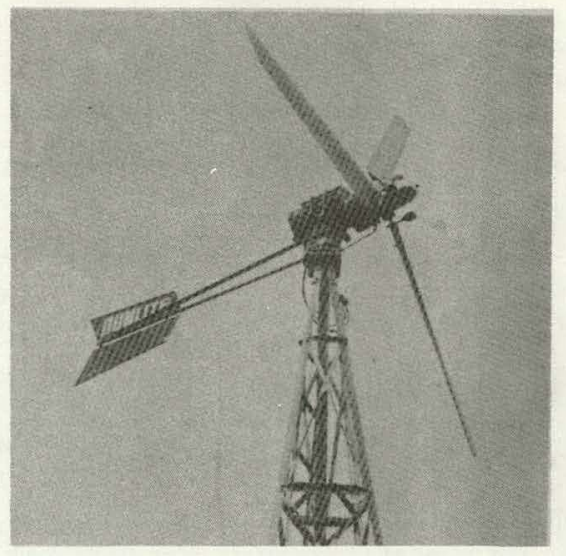

MISCELLANEOUS

Length of time machine has been in operation:

41 years, ( with model changes).

Design Features: Fully enclosed alternator.

Warranty: One year: Parts and Workmanship.

Owners Manual: Available for $\$ 10.00$.

Maintenance Schedule: Annual: Check oil and inspect system. Every five years: Change oil.
PERFORMANCE CHARACTERISTICS

Rated Output: $\quad 2.0 \mathrm{~kW} @ 25 \mathrm{mph},(11 \mathrm{~m} / \mathrm{s})$

Maximum Output: $3.0 \mathrm{~kW} @ 32 \mathrm{mph},(14.3 \mathrm{~m} / \mathrm{s})$

Test Procedures: Wind tunnel (by Australian Government agency.) Performance graph taken from Dunlite Manual, Issue \#1, Fig 3., issued 1972 .

CONVERSION FACTORS

One $\mathrm{mph}=44707 \mathrm{~m} / \mathrm{s}$

One gallon $=3.785$ liters

One foot -.3048 meters

One $\mathrm{ft}^{2}=.09290 \mathrm{~m}^{2}$

One $\mathrm{kW}=1.341 \mathrm{hp}$

One $\mathrm{lbm}=.4536 \mathrm{kG}$

One lbf -4.448 newtons

SYSTEM

OUTPUT

in

Kilowatts

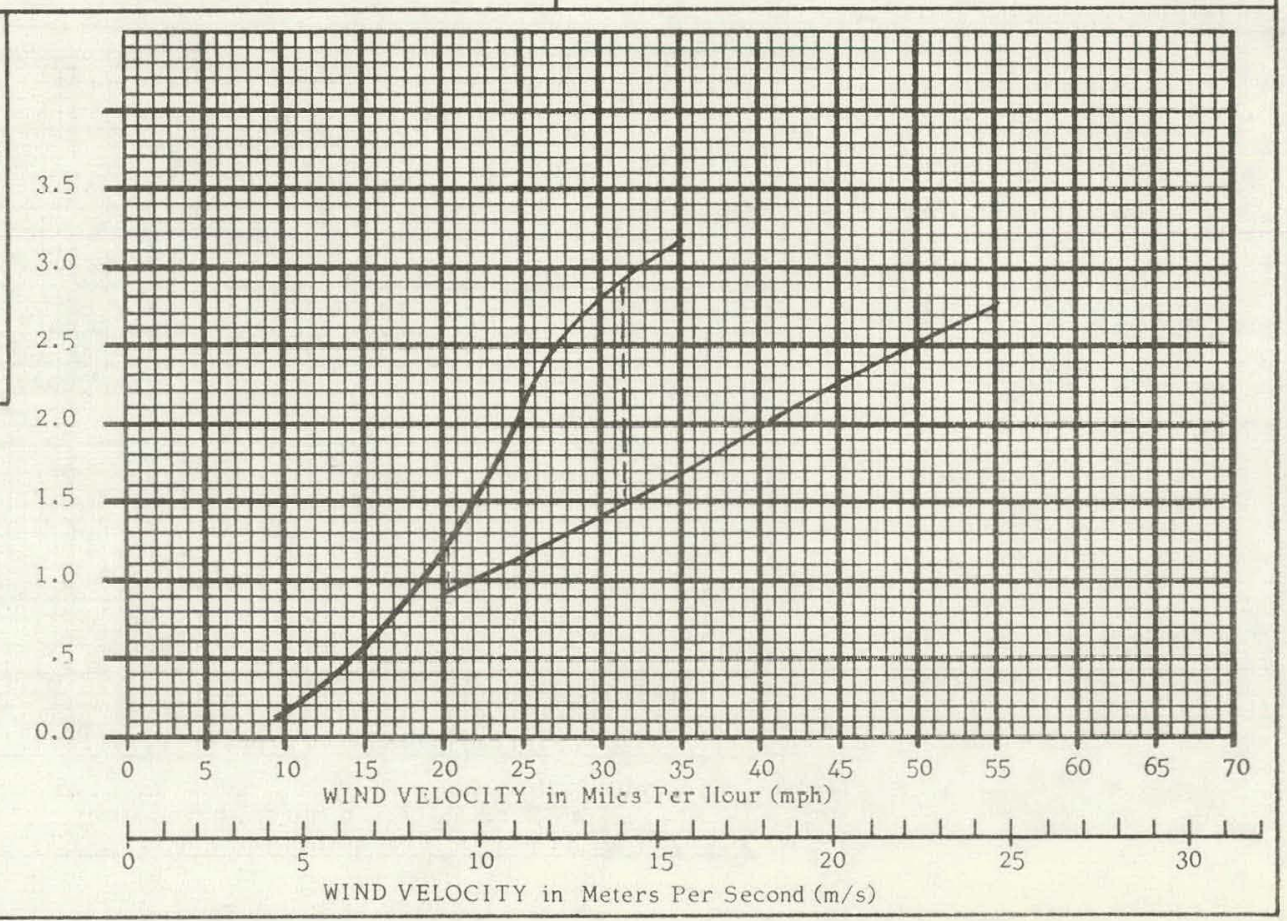


Dynergy

MODEL : 5 Meter VAWT (Prototype)

YPE: Electrical (Also Mechanical Prime Mover)

Manufacturer: Dynergy Corporation

Address: $\quad$ P. O. Box 428, 1269 Union Avenue Laconia, New Hampshire 03246

Contact: Robert B. Allen, Vice President

Telephone: (603) $524-8313$

PHYSICAL CHARACTERISTICS

Generic Description: Vertical Axis, Darrieus

Capture Area: $\quad 150 \mathrm{ft}^{2},\left(13.9 \mathrm{~m}^{2}\right)$

Rotor Diameter: $\quad 15 \mathrm{ft},\left(\begin{array}{lll}4.6 & \mathrm{~m}\end{array}\right)$

System Weight: $\quad 850$ lbs, ( 386 kGs)

Rotor Weight: $\quad 312$ lbs, ( 244 kGs)

Blade Materials: Aluminum, 6061-T6, Extruded

Number of Blades: Three (3)

OPERATIONAL CHARACTERISTICS

Cut-In Wind Speed: $\quad 10 \mathrm{mph},(\quad 4.4 \mathrm{~m} / \mathrm{s})$

Shut-Down Wind Specd: N.A. mph, ( N.A.m/s)

Survival Wind Speed: $\quad 100 \cdot \mathrm{mph},(44.7 \mathrm{~m} / \mathrm{s})$

RPM at Rated Output: $\quad 200 \mathrm{rpm} @ 24 \mathrm{mph},(10.7 \mathrm{~m} / \mathrm{s})$

Maximum RPM: $\quad 300 \mathrm{rpm} @$ any $\mathrm{mph},($ any $\mathrm{m} / \mathrm{s})$

Axial Thrust @ Rated Wind Speed: N. A.

Maximum Axial Thrust: $\quad 1200 \mathrm{lbs},(5338 \mathrm{~N}$ )

Overspeed Control: Mechanical caliper on 24" diameter disc brake.

Aerodynamic stall tends to prevent excessive RPM.

Generator/Alternator: Available

Pump/Compressor: Available

Voltage Regulation: Available

Mechanical Power Transmission: Purchased separately,

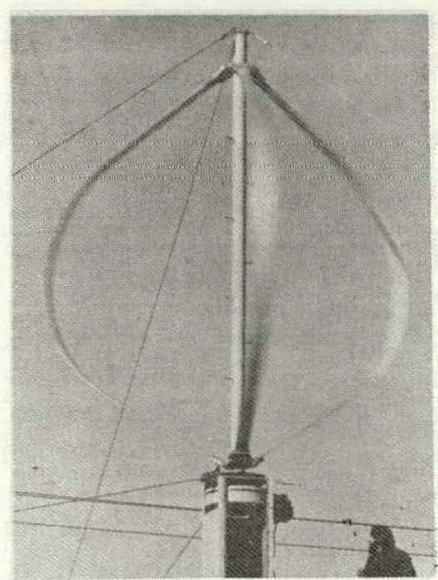

MISCELLANEOUS

Length of time machine has been in speratinn.

Since December of 1977.

Design Features: Adaptable to a wide variety of driven devices.

Also in anaiysis stage of vertical stacking of Dynergy VAWT for increased power output.

Warranty: Available.

Owners Manual: Available

Maintenance Schedule: Semi-annually: inspect system, lubricate.

NOTES:

Prototye unit used an alternator manufactured by

Zephyr Wind Dynamo Co.

Air foil used is NACA OU15, with 6 inch chord.

Marimum Output: N.A.
Test Procedures: $\Lambda l l$ output data based on initial test runs.

One $\mathrm{mph}=.44707 \mathrm{~m} / \mathrm{s}$

One gallon $=3.785$ liters

Une toot $=.3048$ meters

One $\mathrm{ft}^{2}=.09290 \mathrm{~m}^{2}$

One kW - 1.341 hp

One $\mathrm{lbm}=.4536 \mathrm{kG}$

One $\mathrm{lbf}=4.448$ newtons

SYSTEM

OUTPUT

in

Kilowatts

and

Horsepower

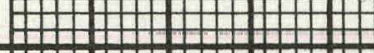

H
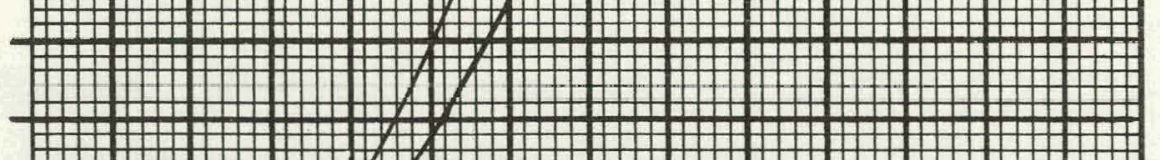

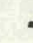
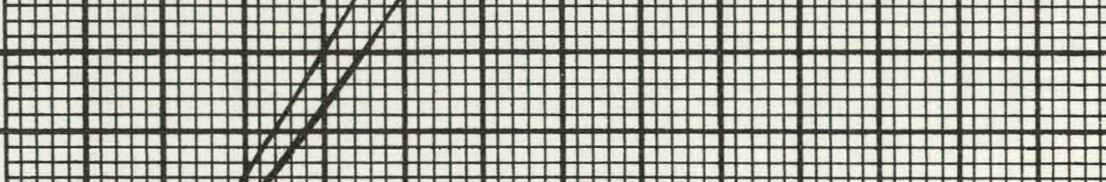

0.0
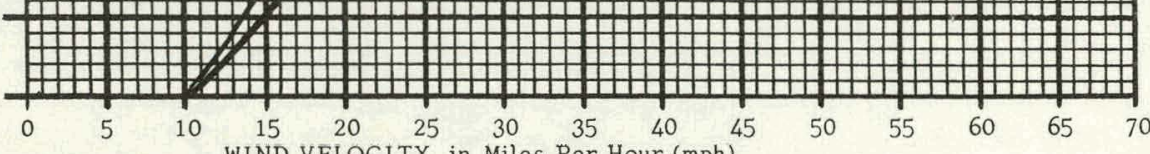

WIND VELOCITY in Miles Per Hour (mph)

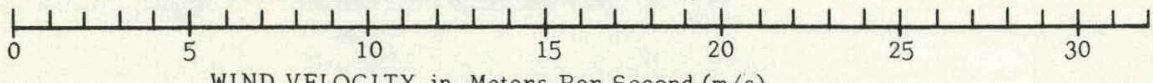




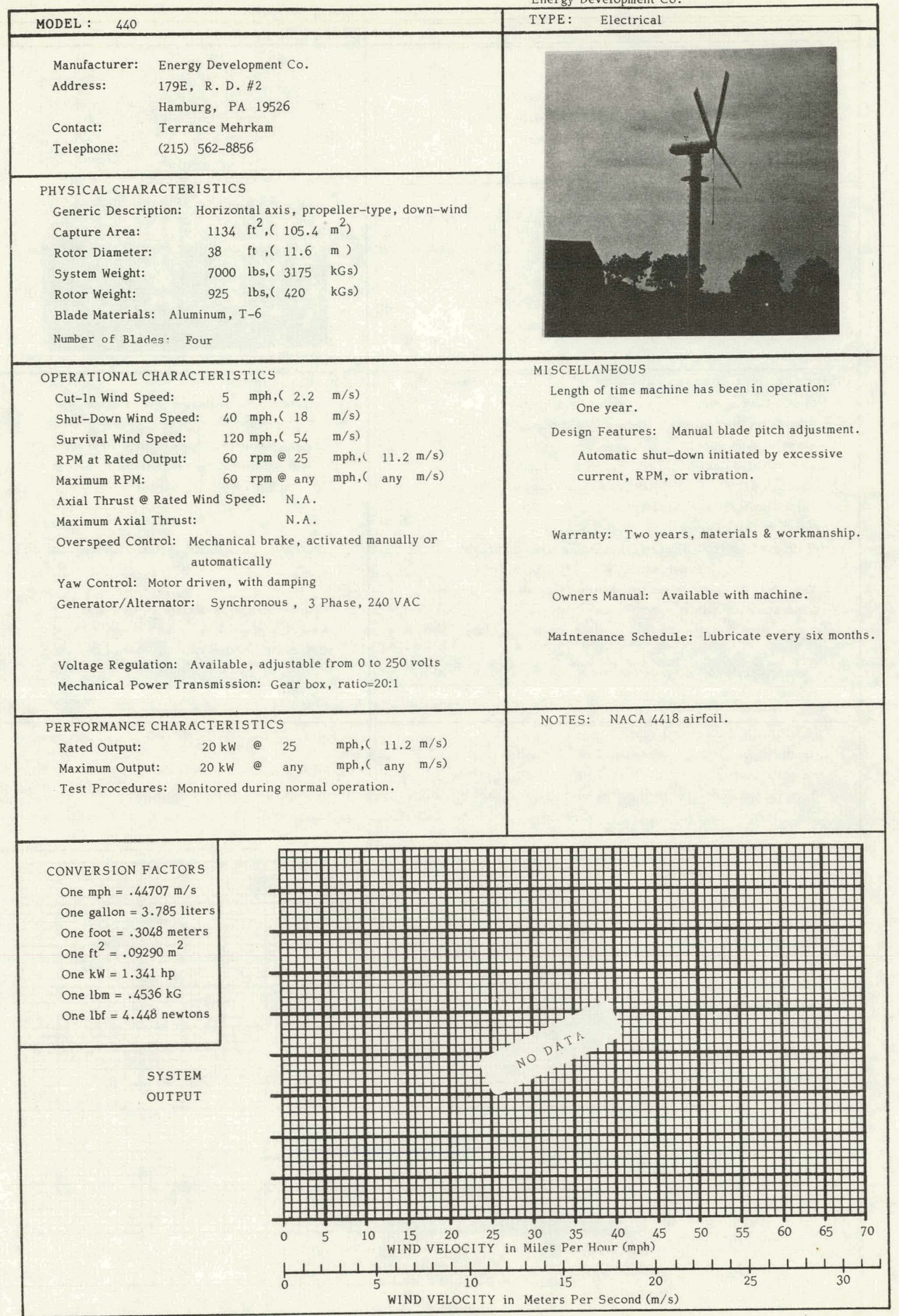




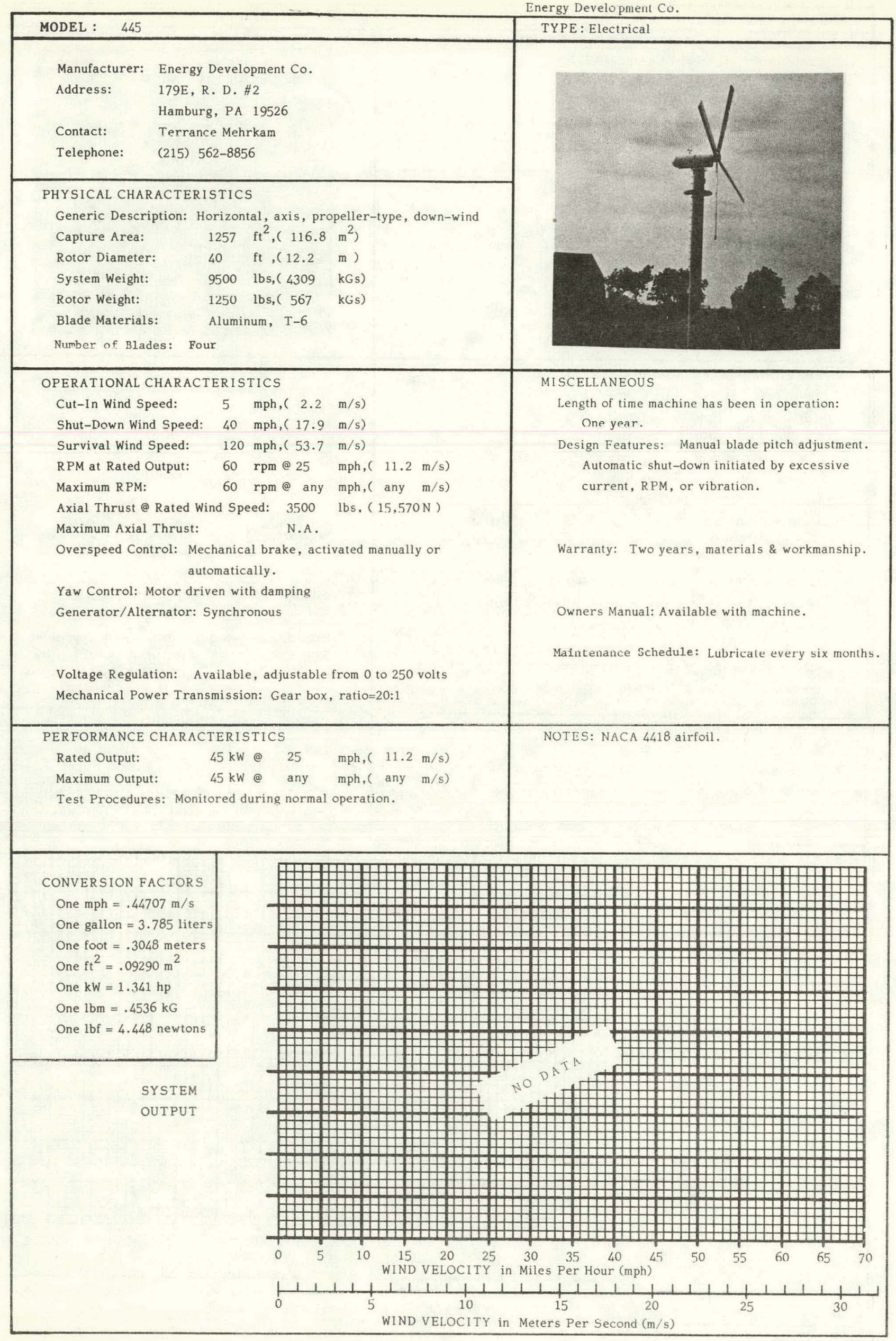




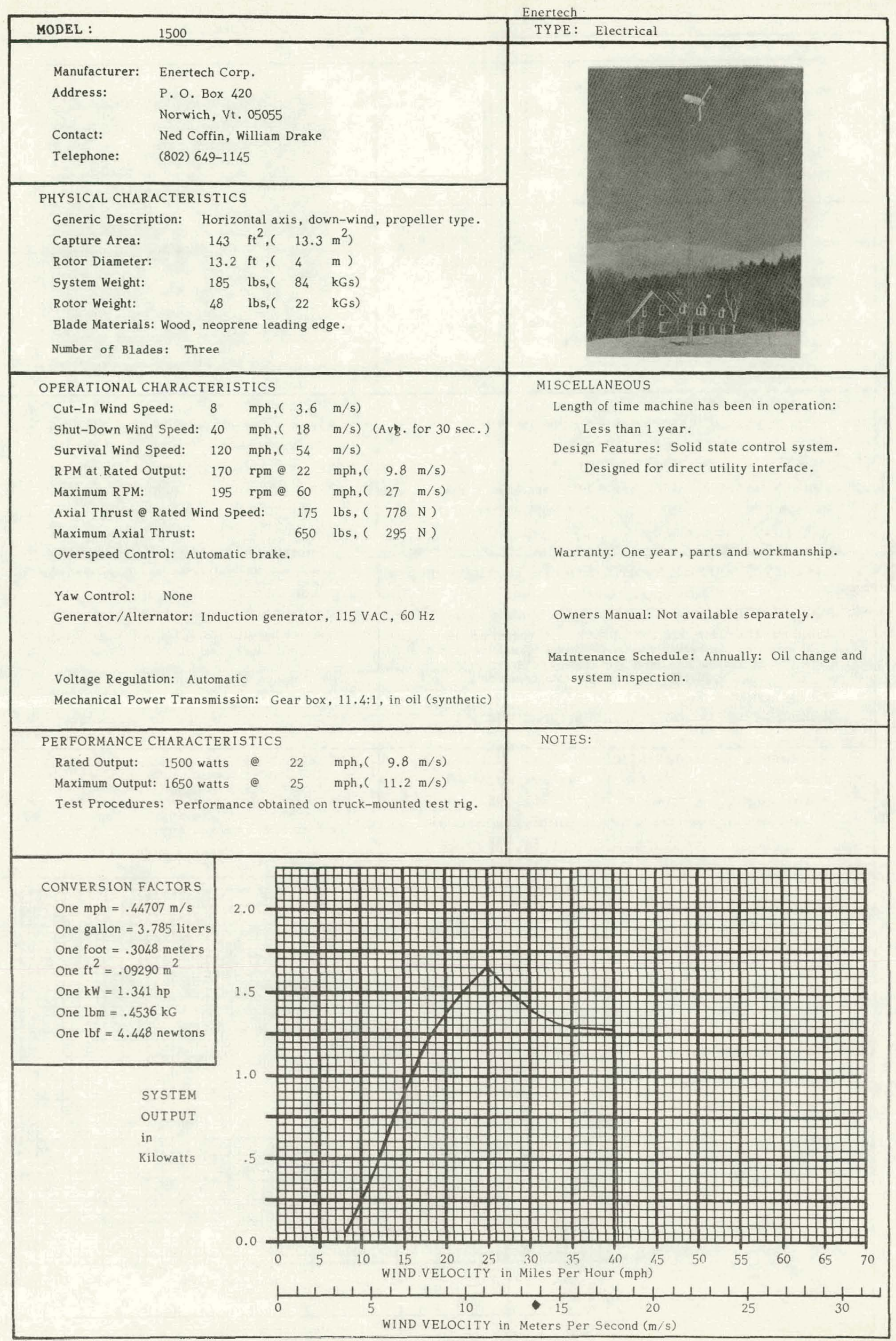


Grumman Energy Systems, Inc.

MODEL : Windstream 25-B

Manufacturer: Grumman Energy Systems, Inc.

Address: $\quad 4175$ Veterans Memorial Highway

Ronkonkoma, New York 11779

Contact: Mr. J.K. Stotz Jr.

Telephone: (516) 575-5584

PHYSICAL CHARACTERISTICS

Generic Description: Horizontal axis, propeller-type, down-wind.

Capture Area: $\quad 491 \mathrm{ft}^{2},\left(45.6 \mathrm{~m}^{2}\right)$

Rotor Diameter: $\quad 25 \mathrm{ft},(7.62 \mathrm{~m})$

System Weight: 2000 lbs, ( 906 kGs)

Rotor Weight: $\quad 750$ lbs, ( $340 \mathrm{kGs}$ )

Blade Materials: Aluminum, extruded, 6063T6

TYPE : Electrica

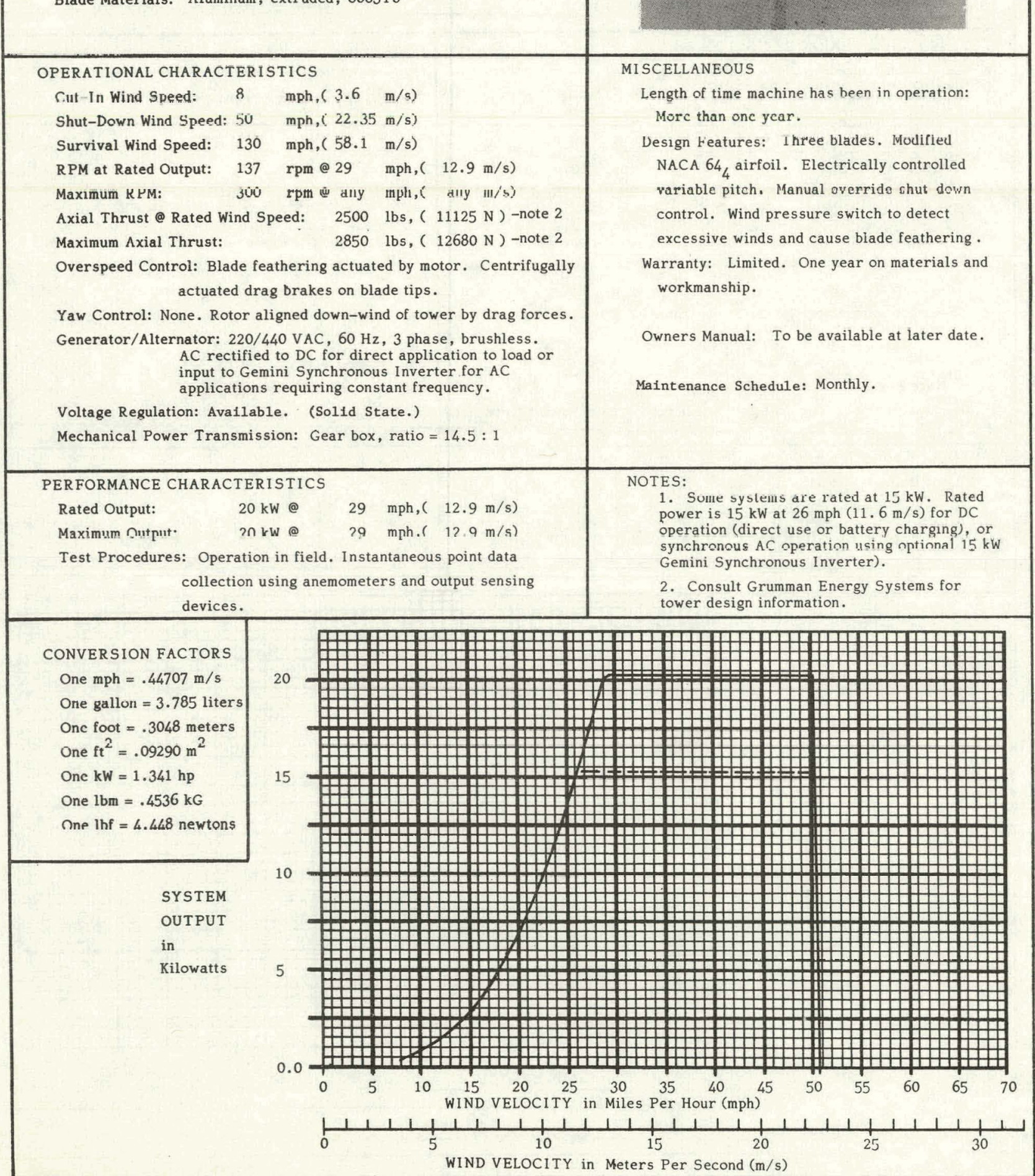




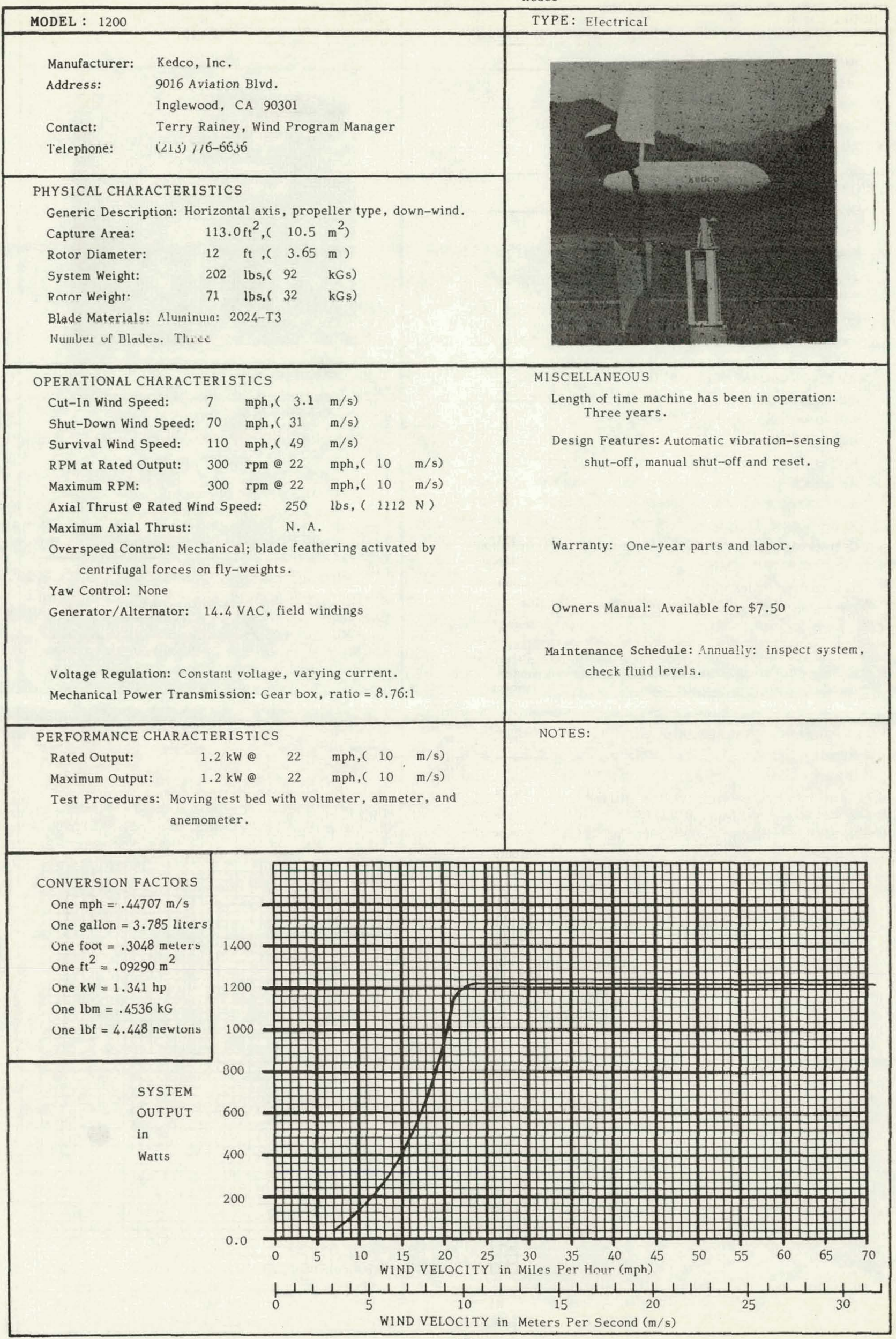




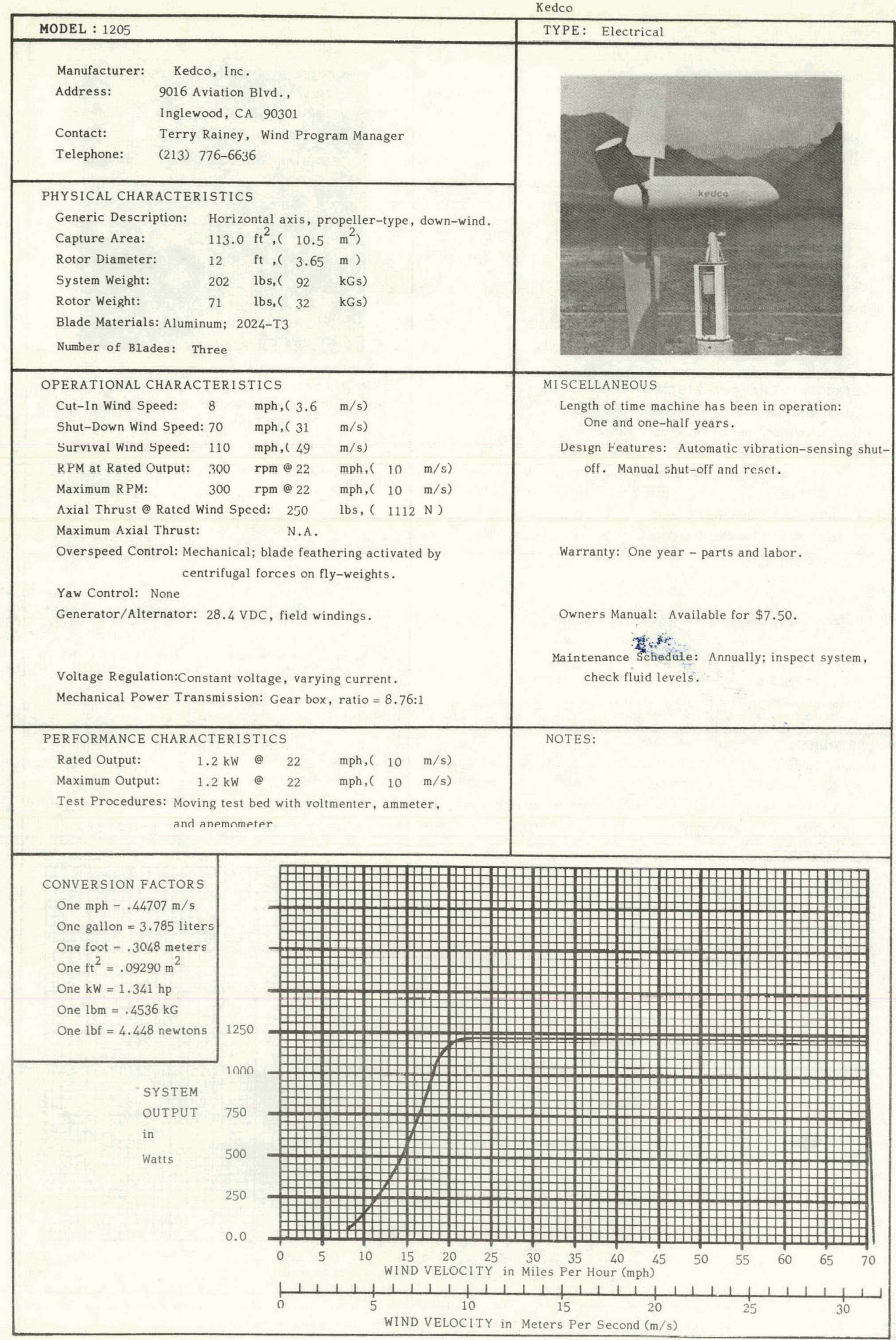




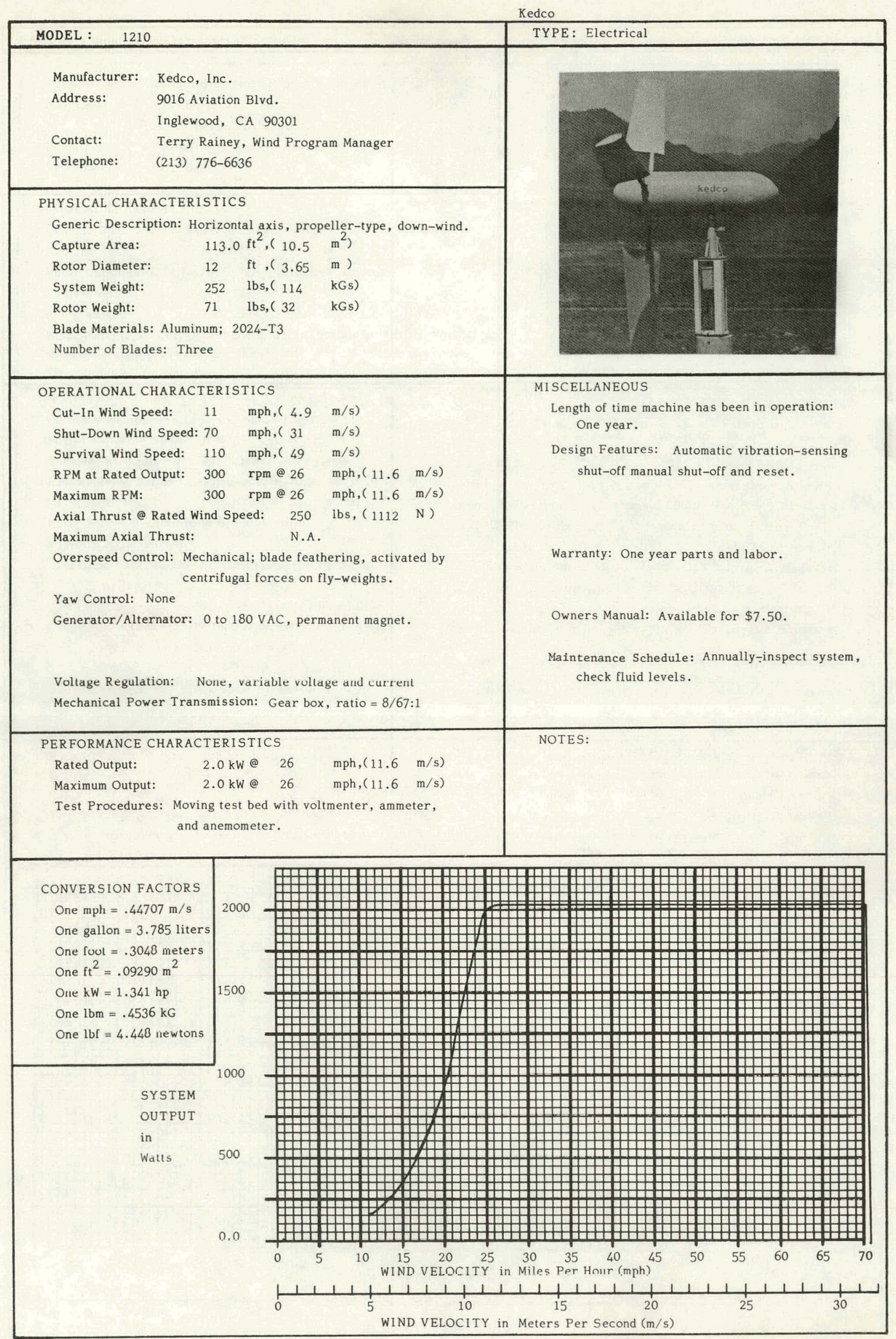




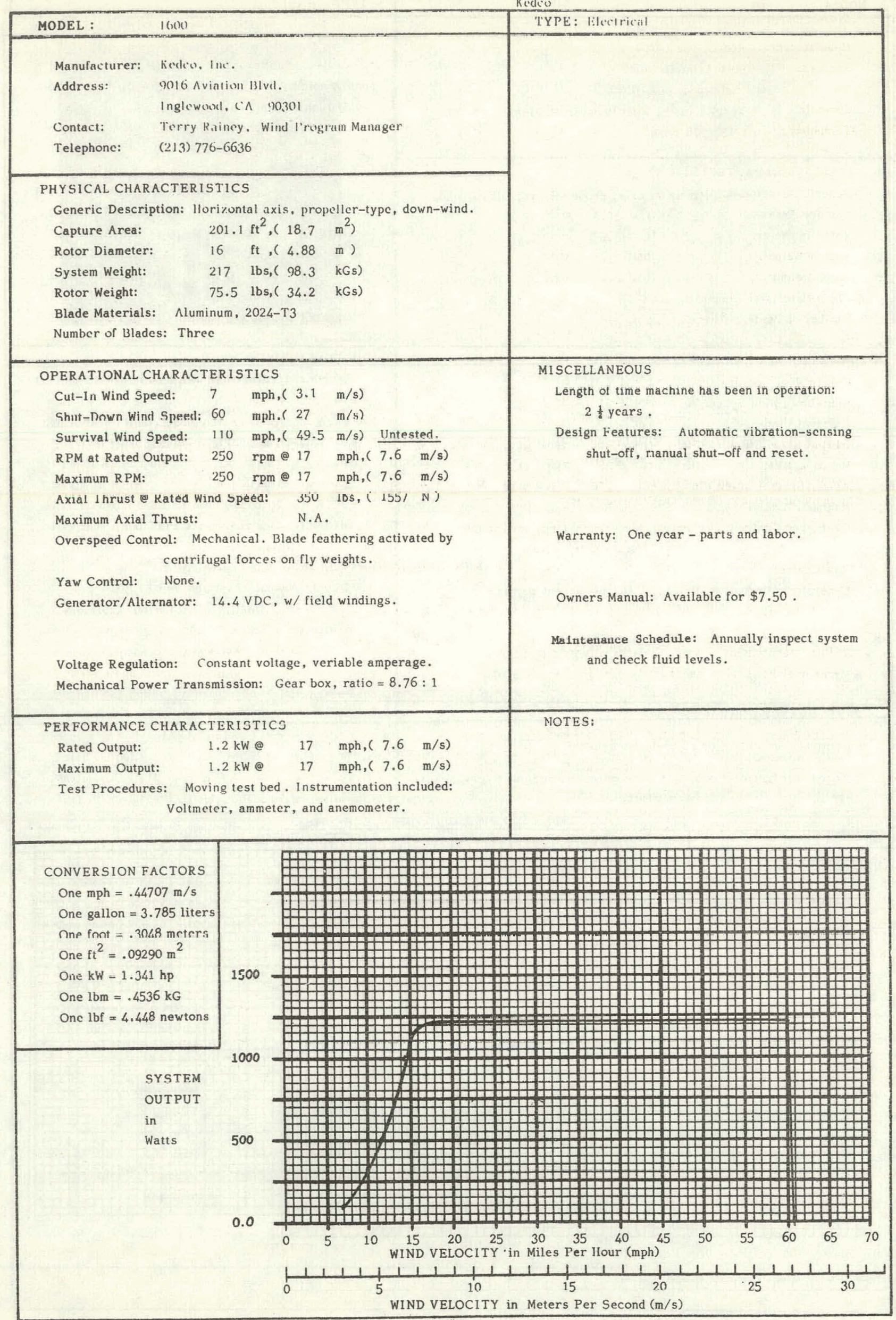


Kedco

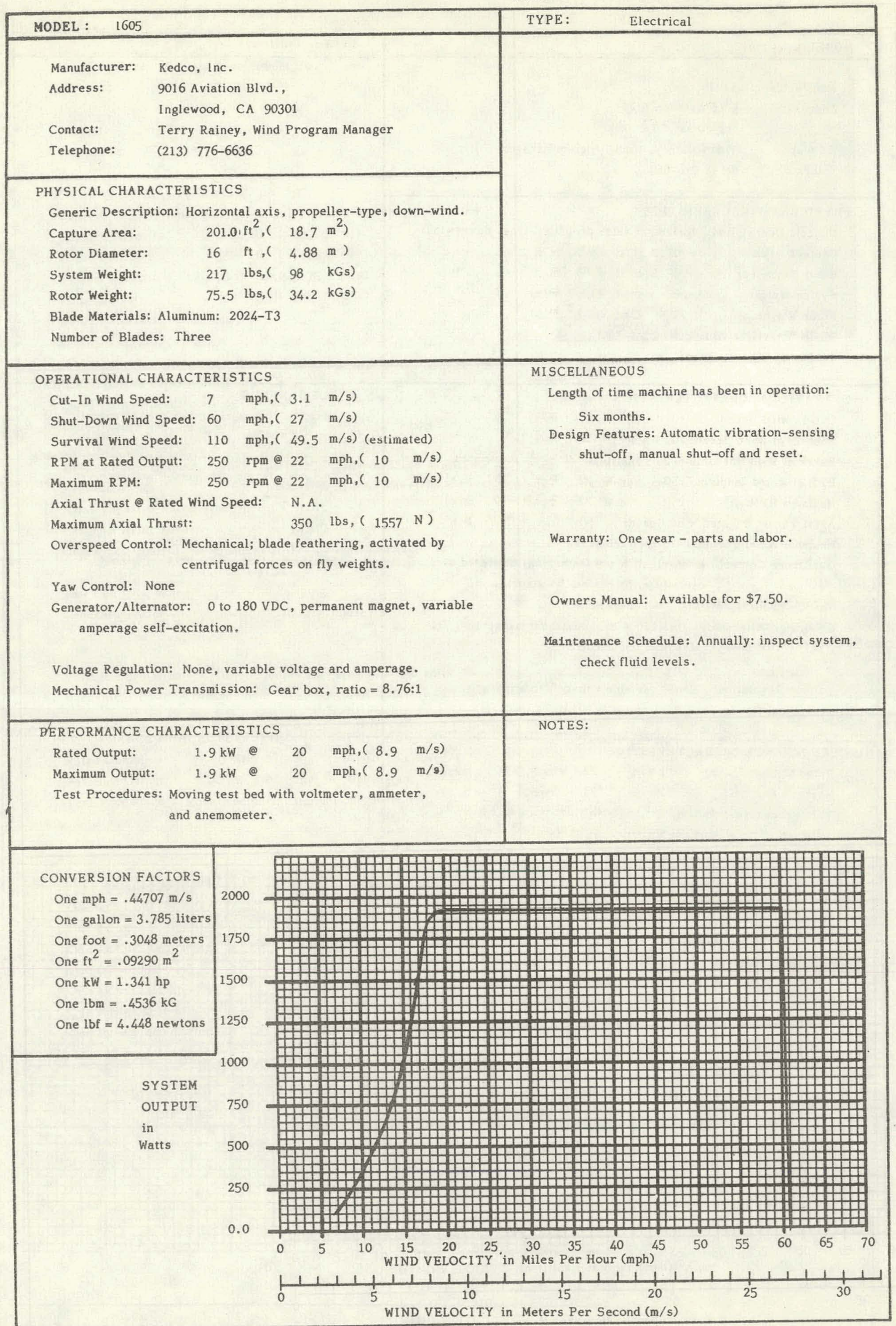




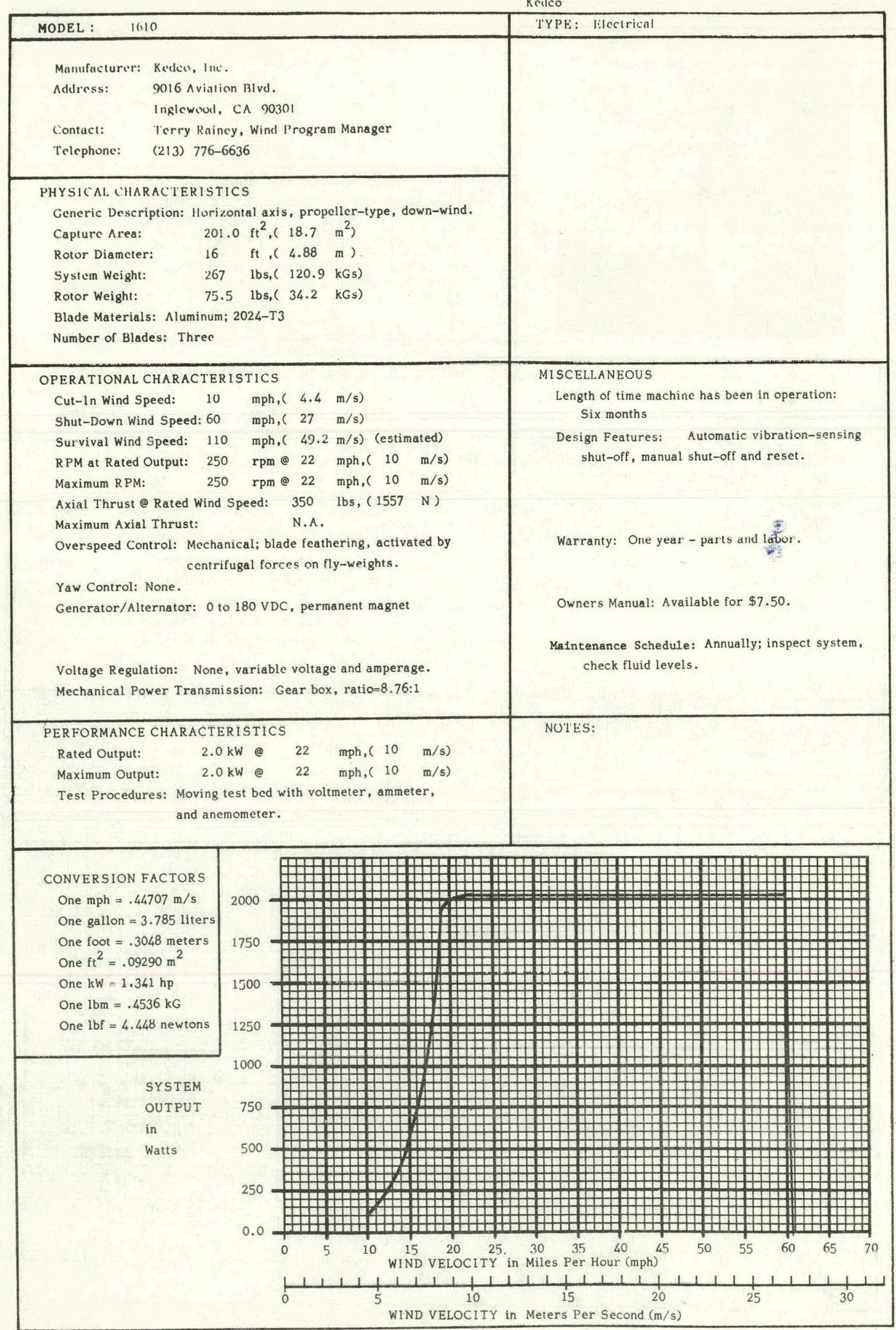


Kedes

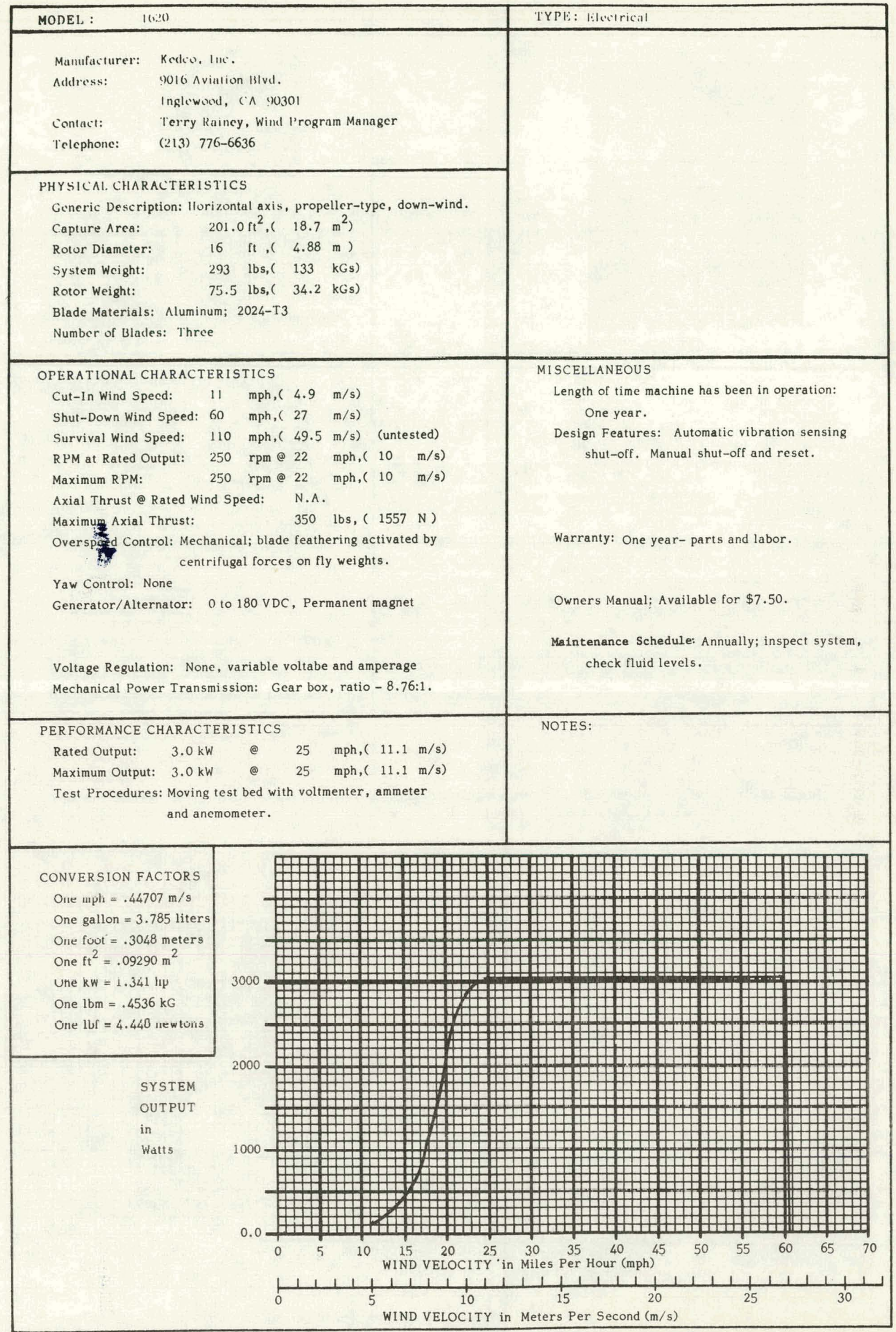




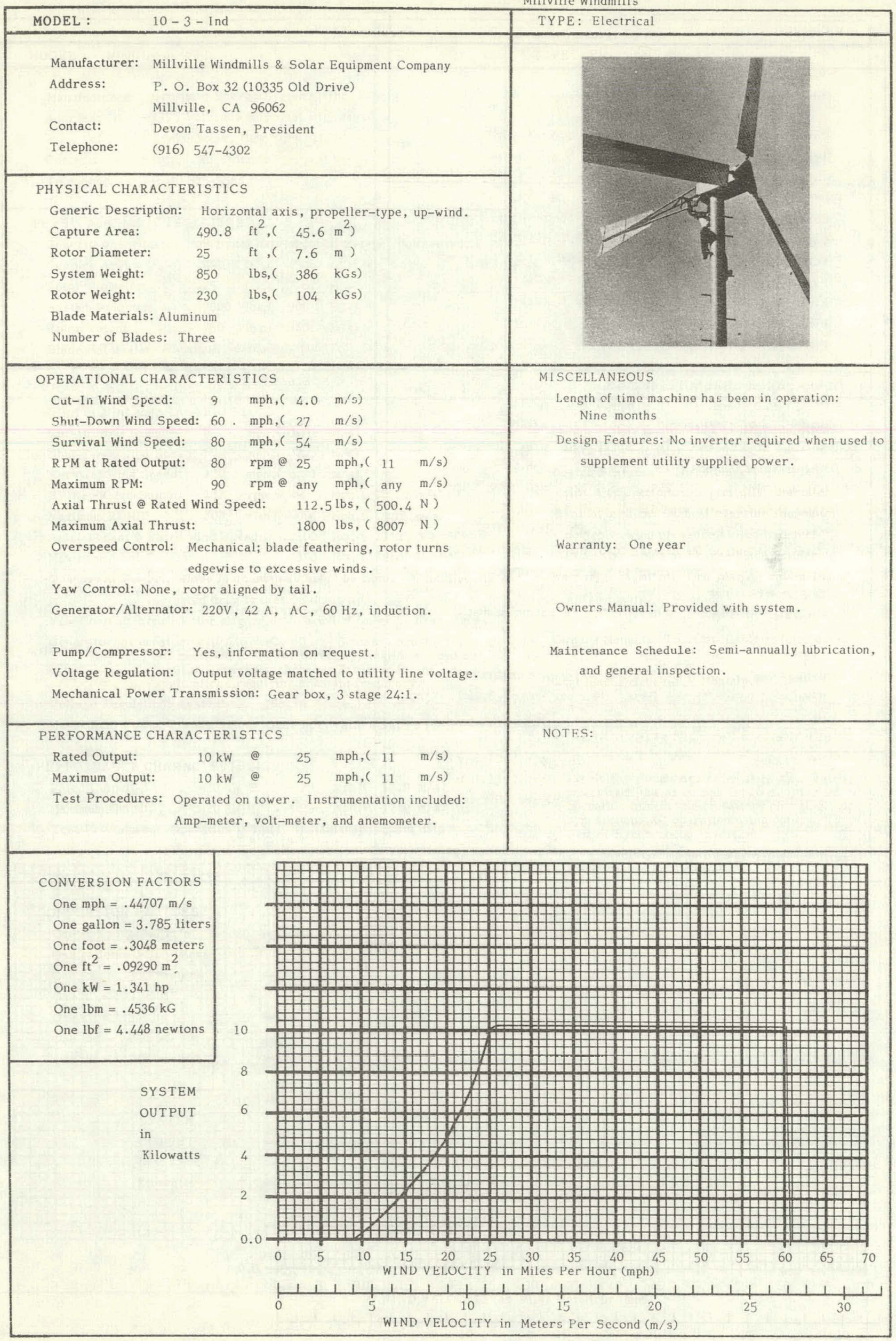


North Wind Power

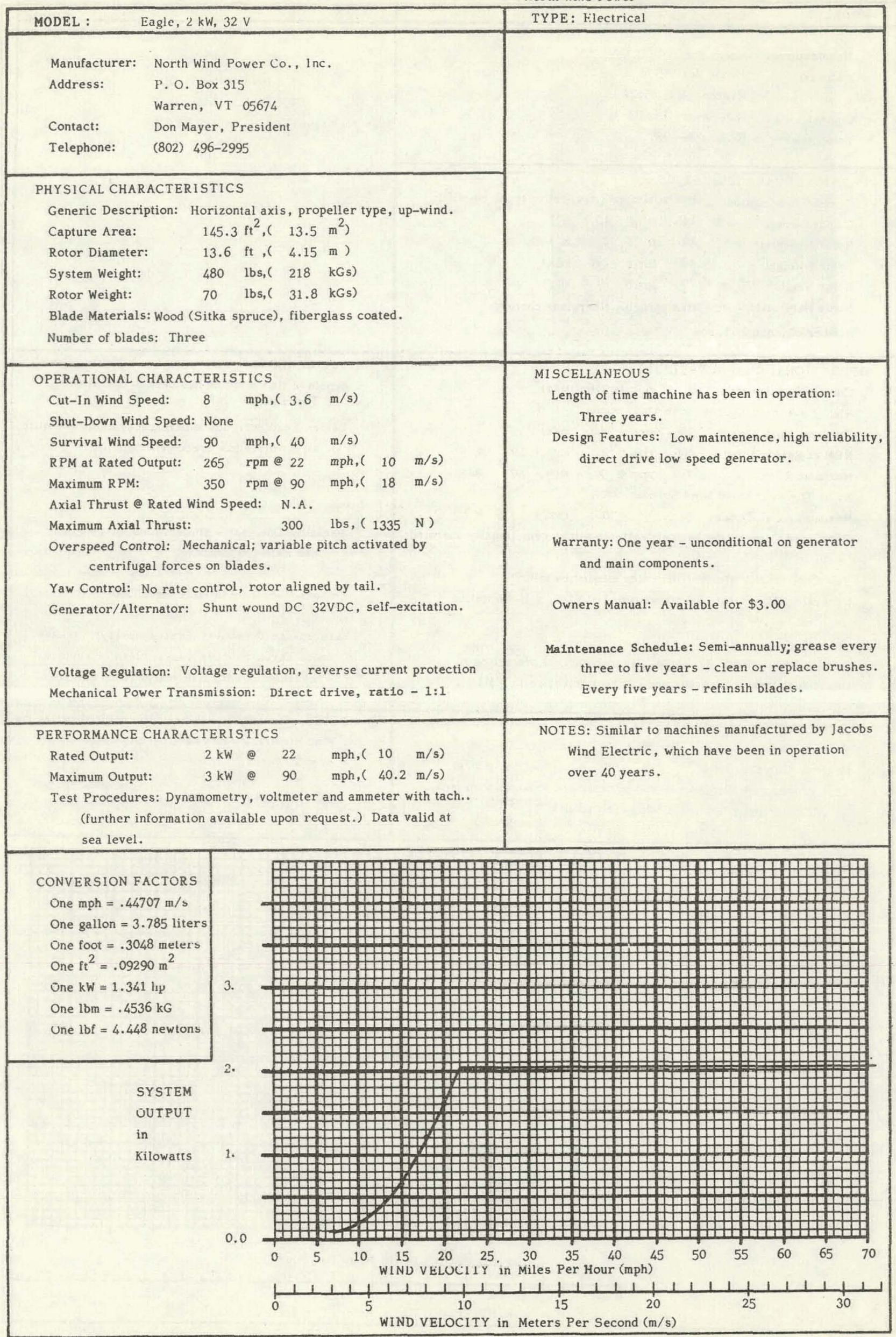




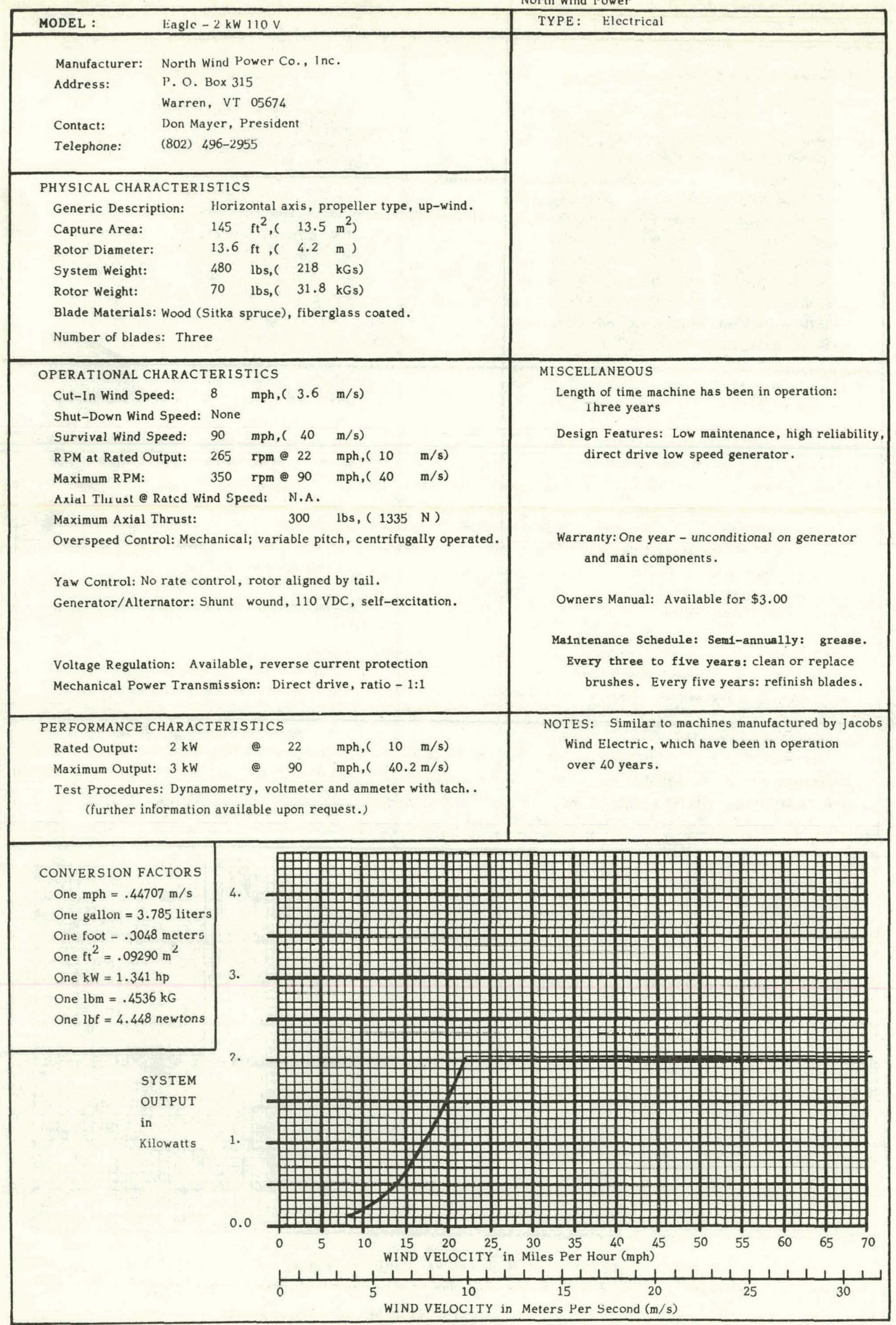


North Wind Power

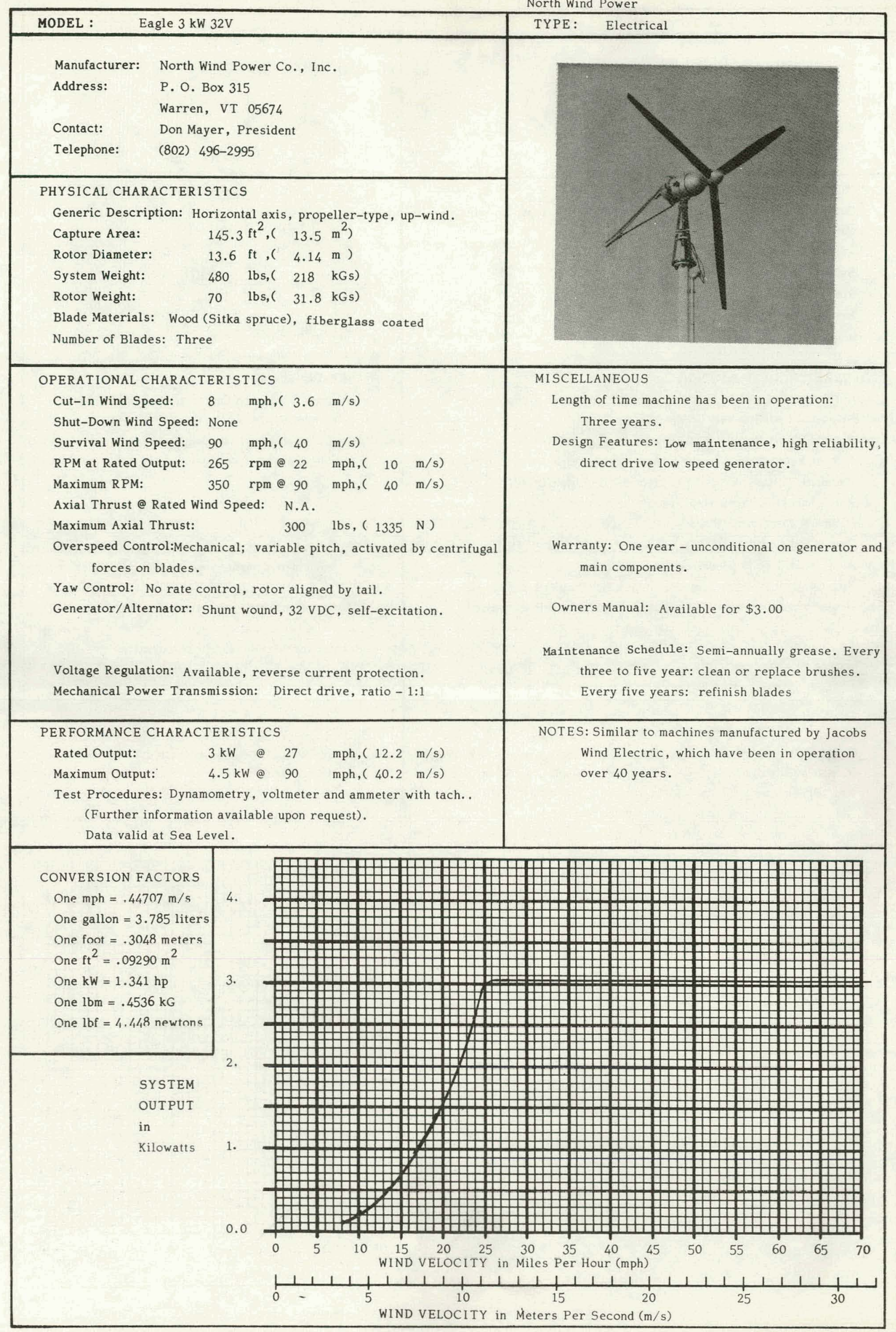




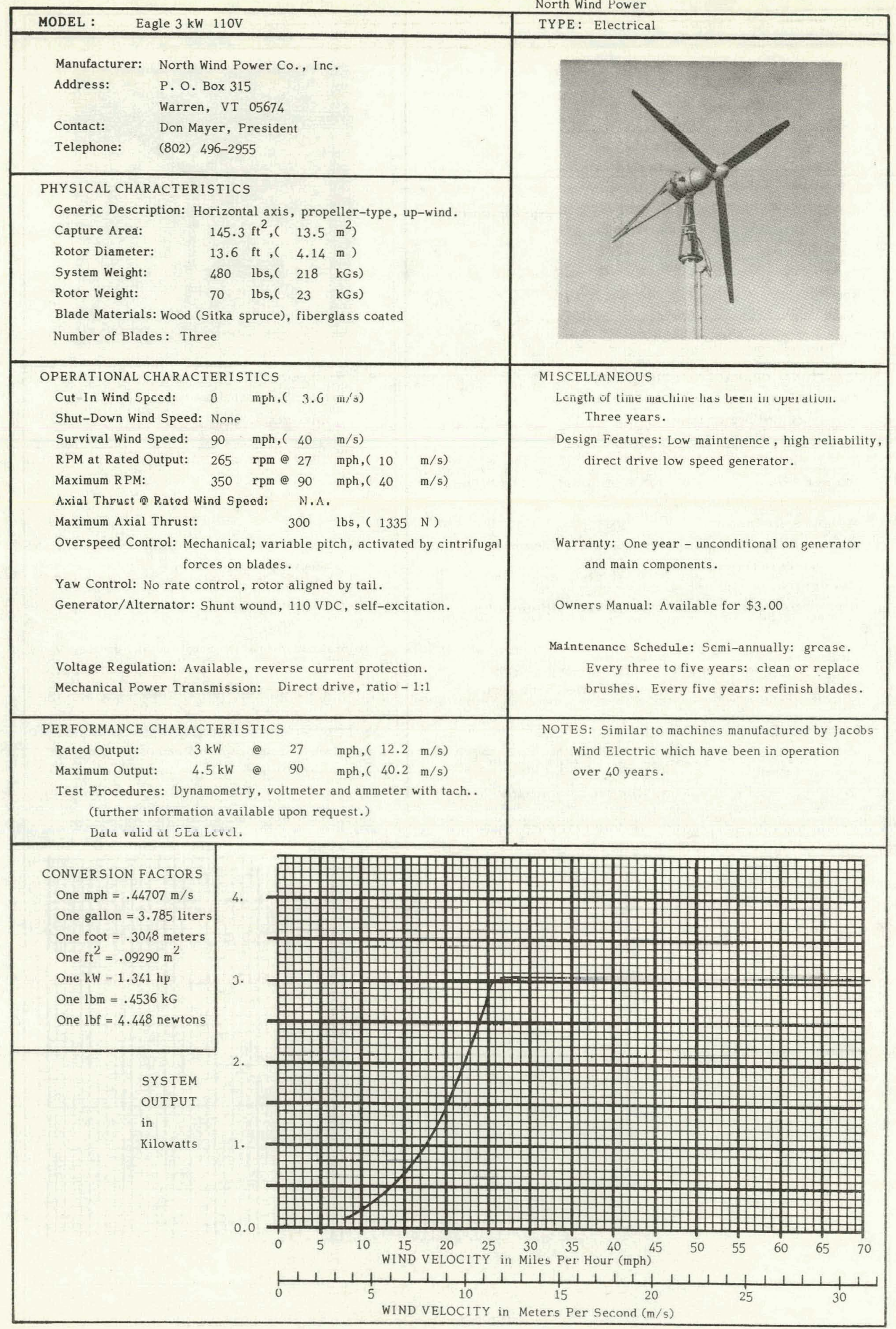


Pinson Energy

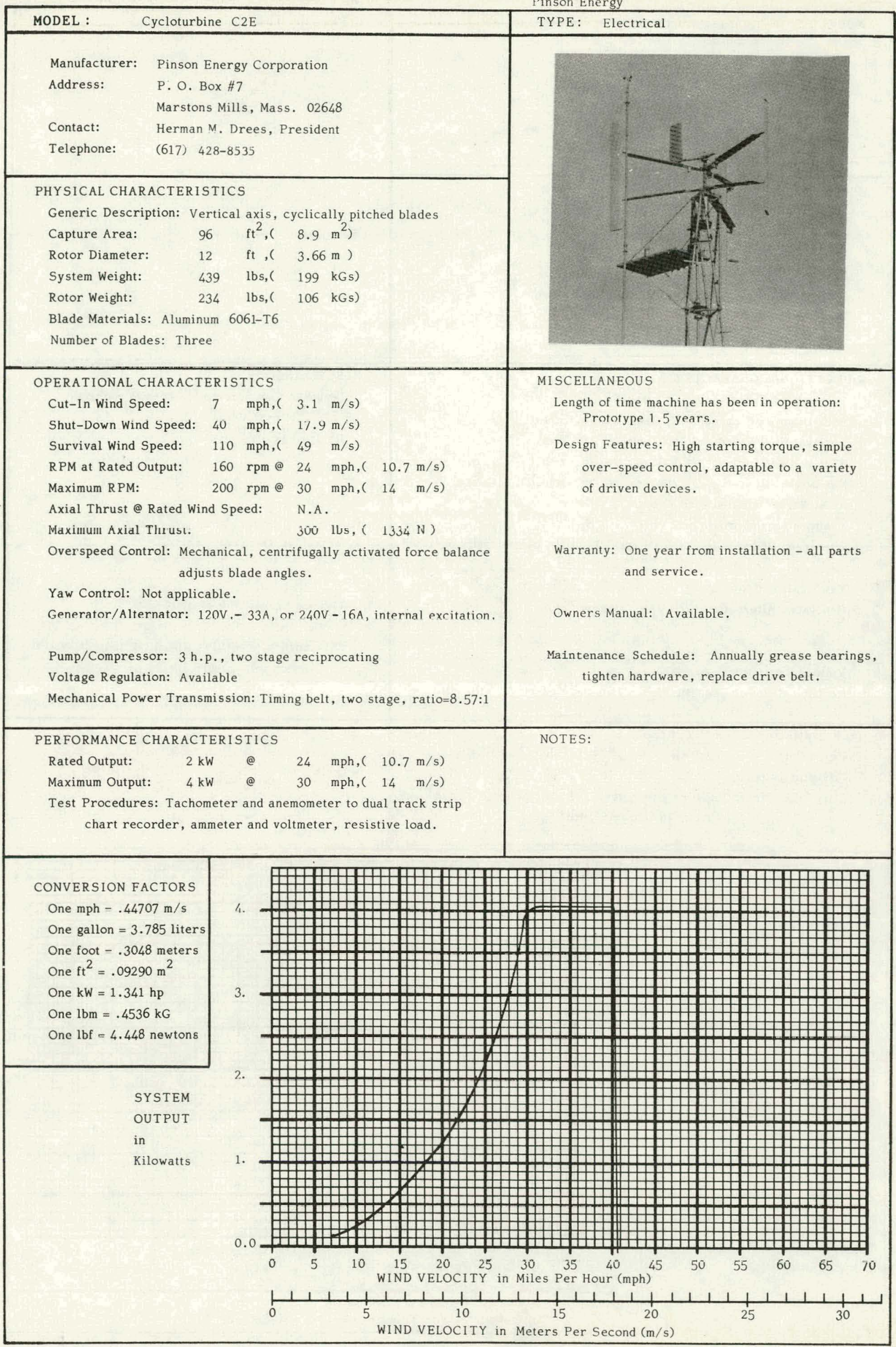




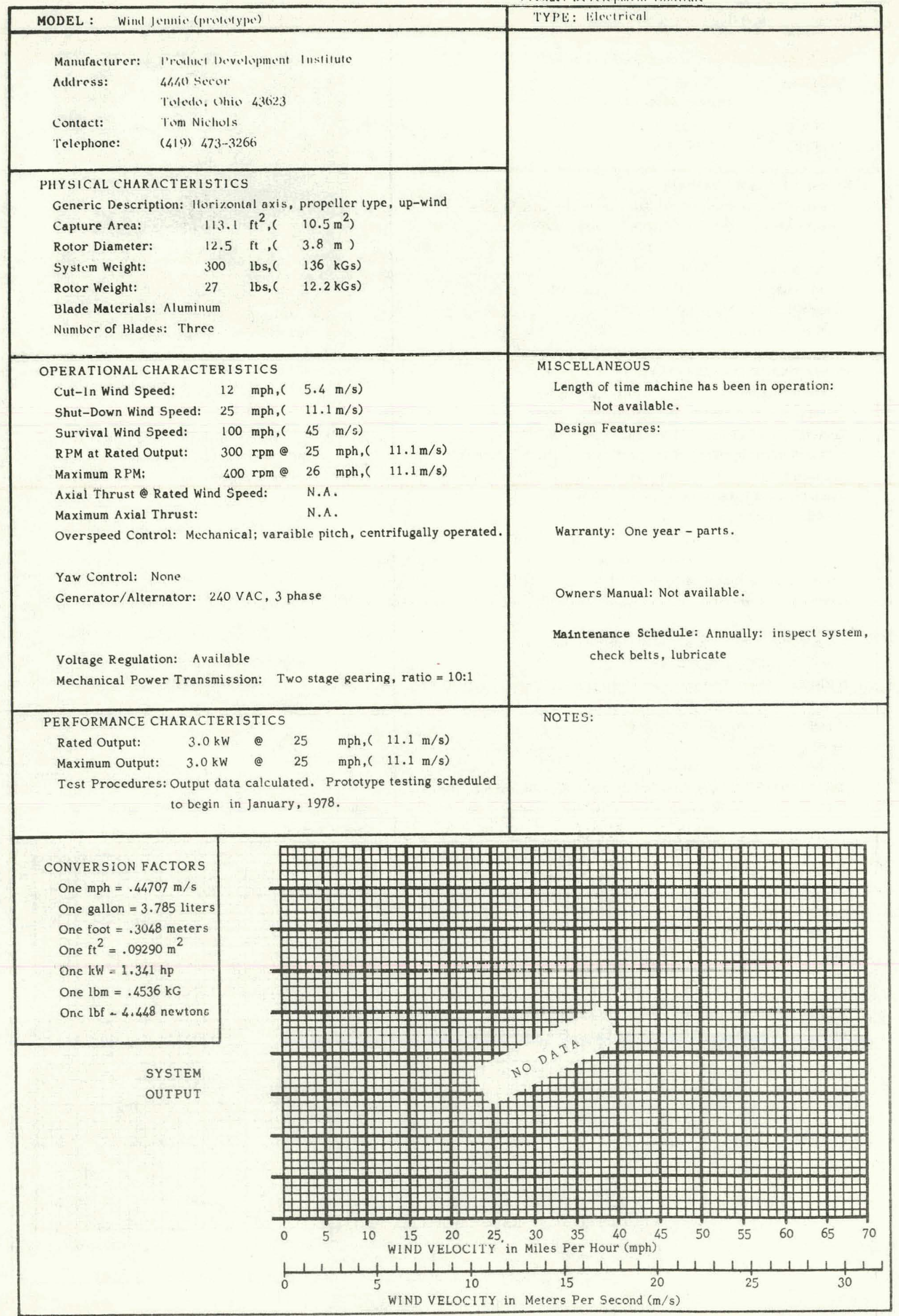




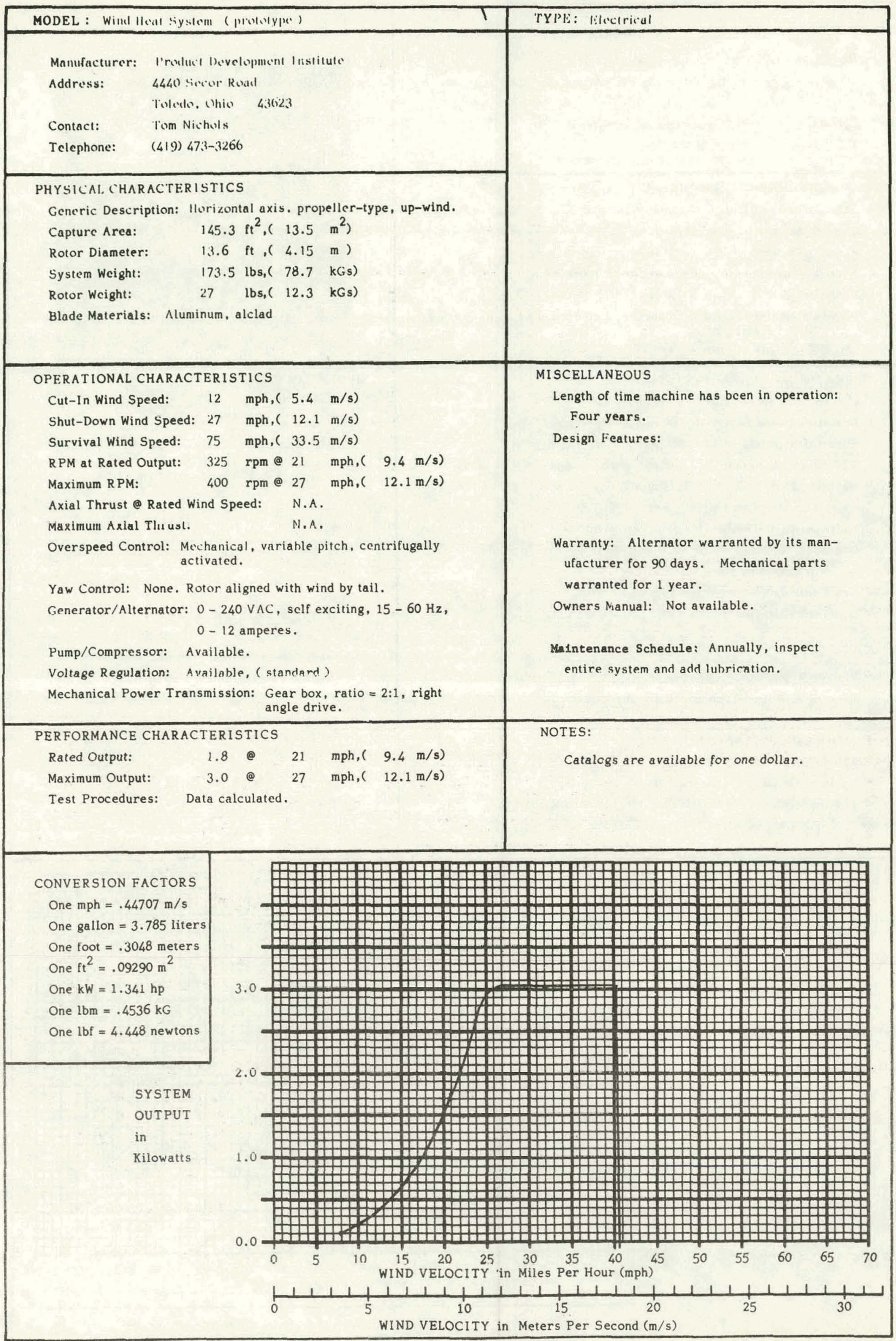




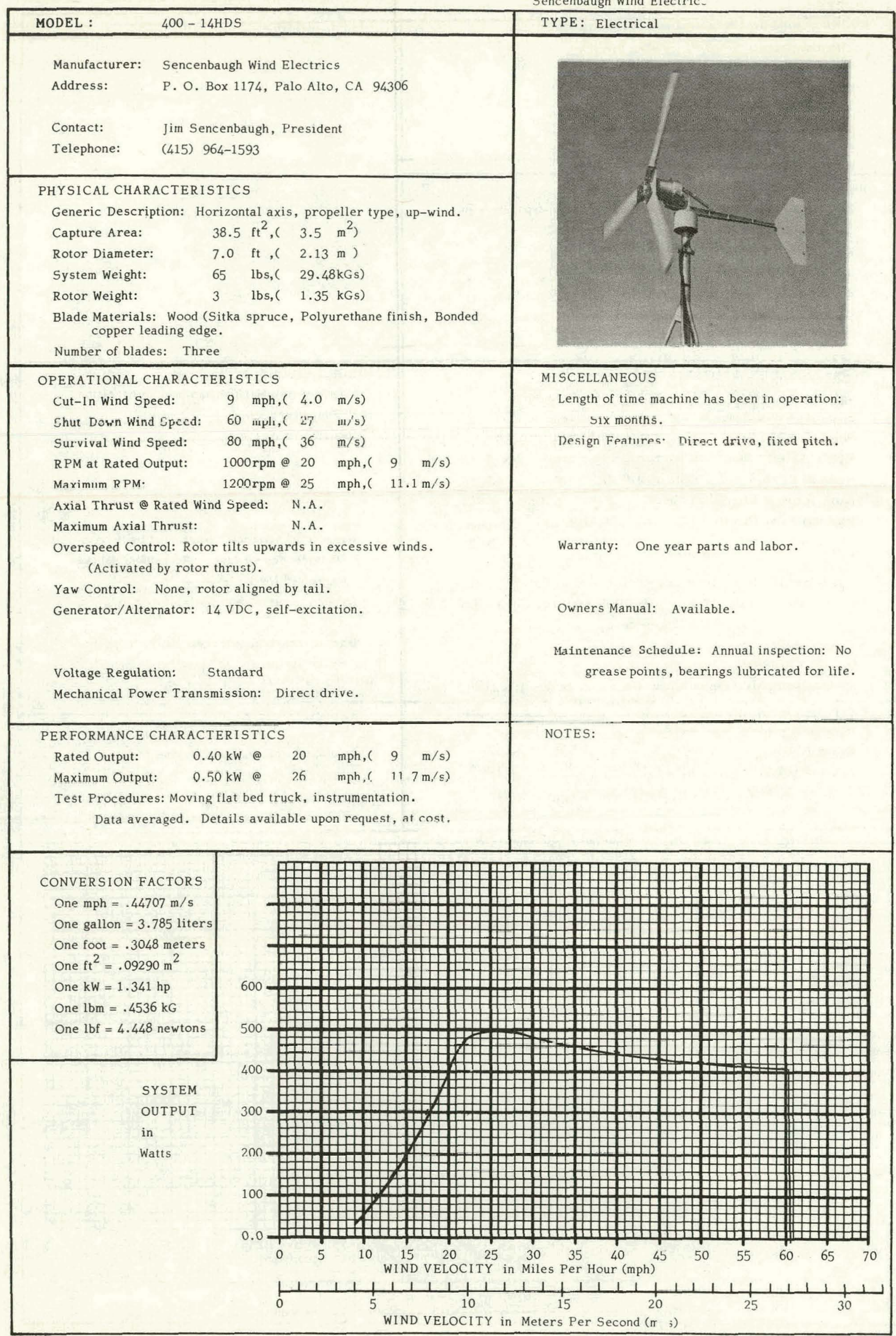




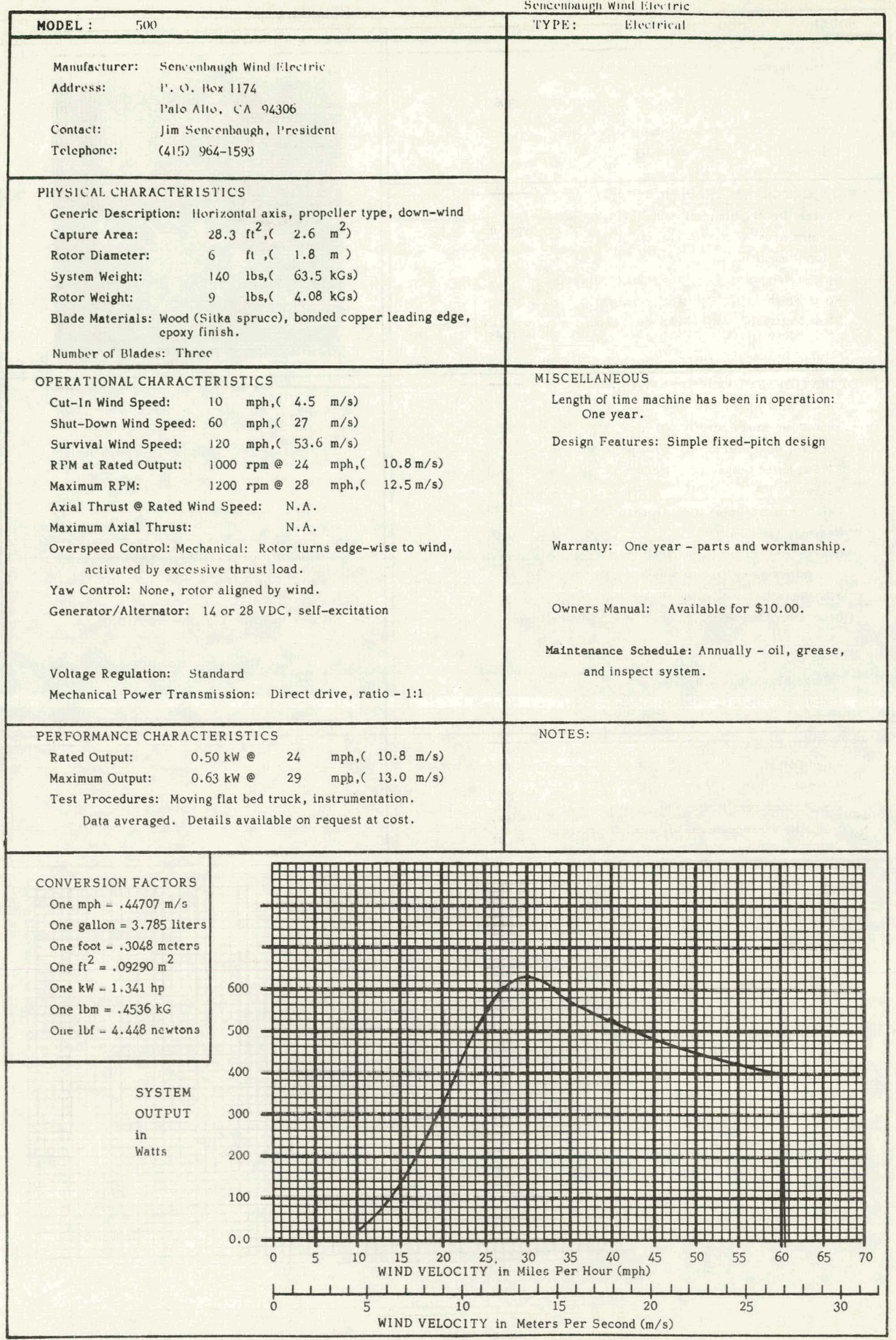




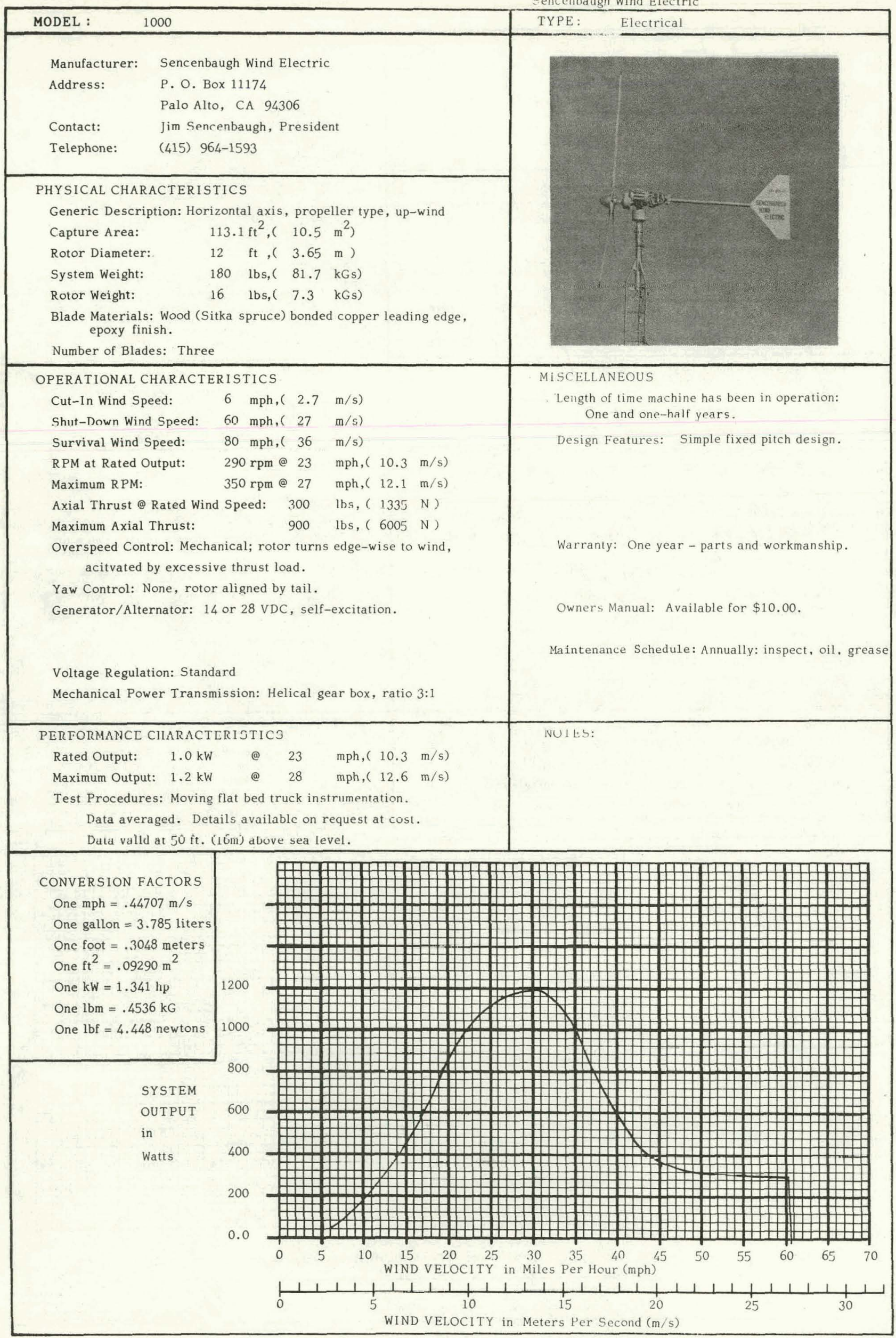


WhirlWird Power Company

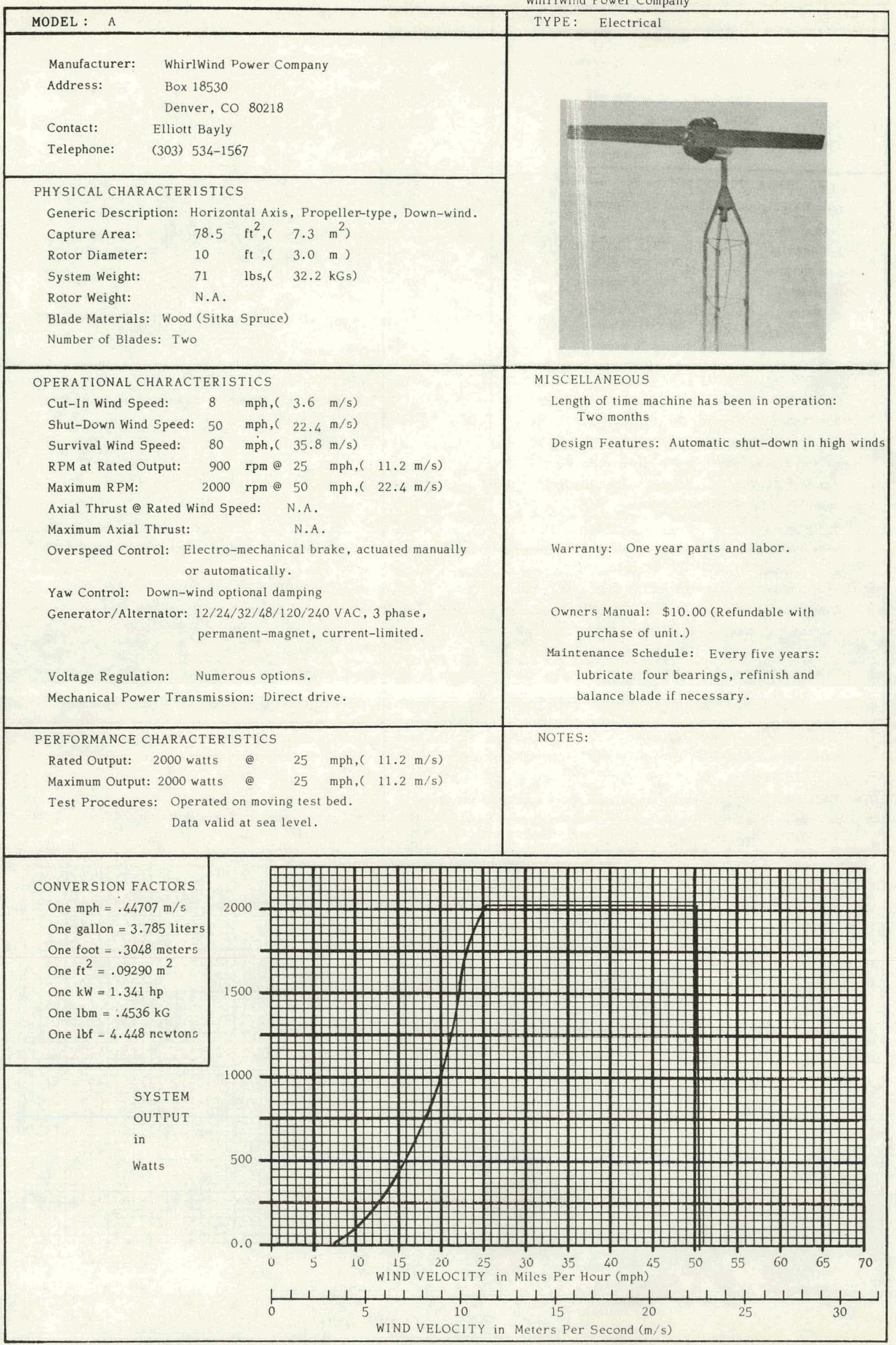


Winco

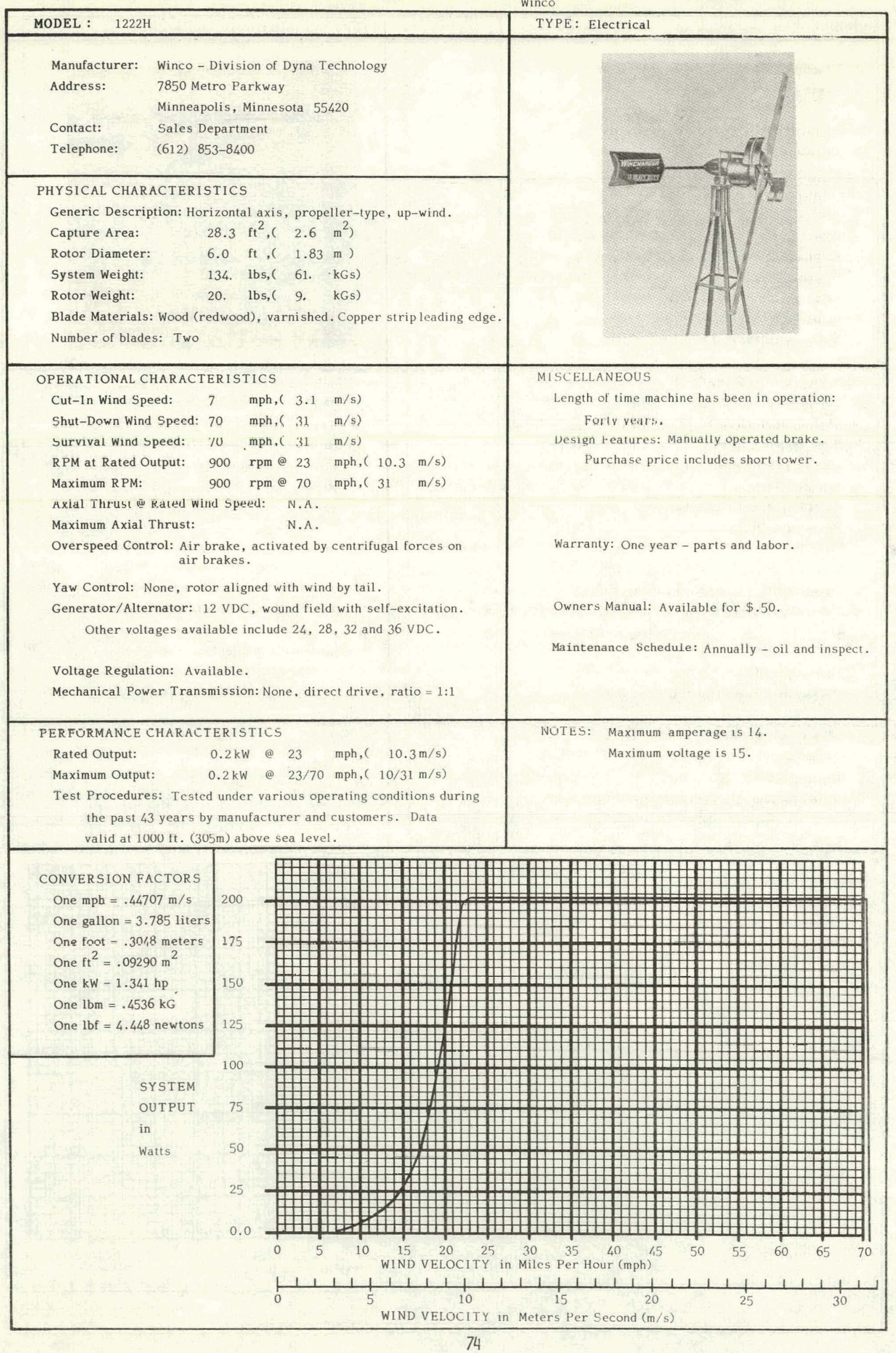


Wind Power Systems

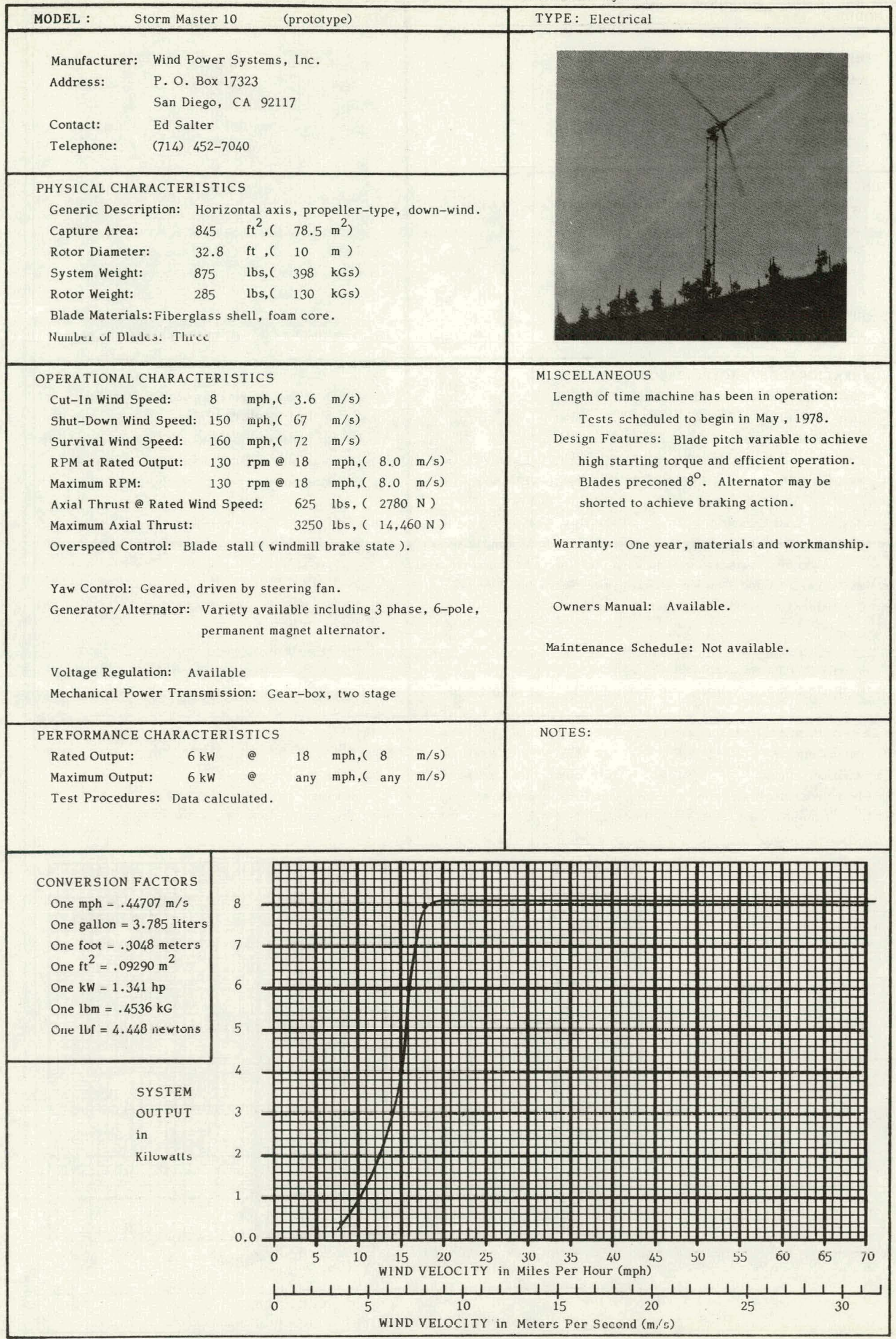




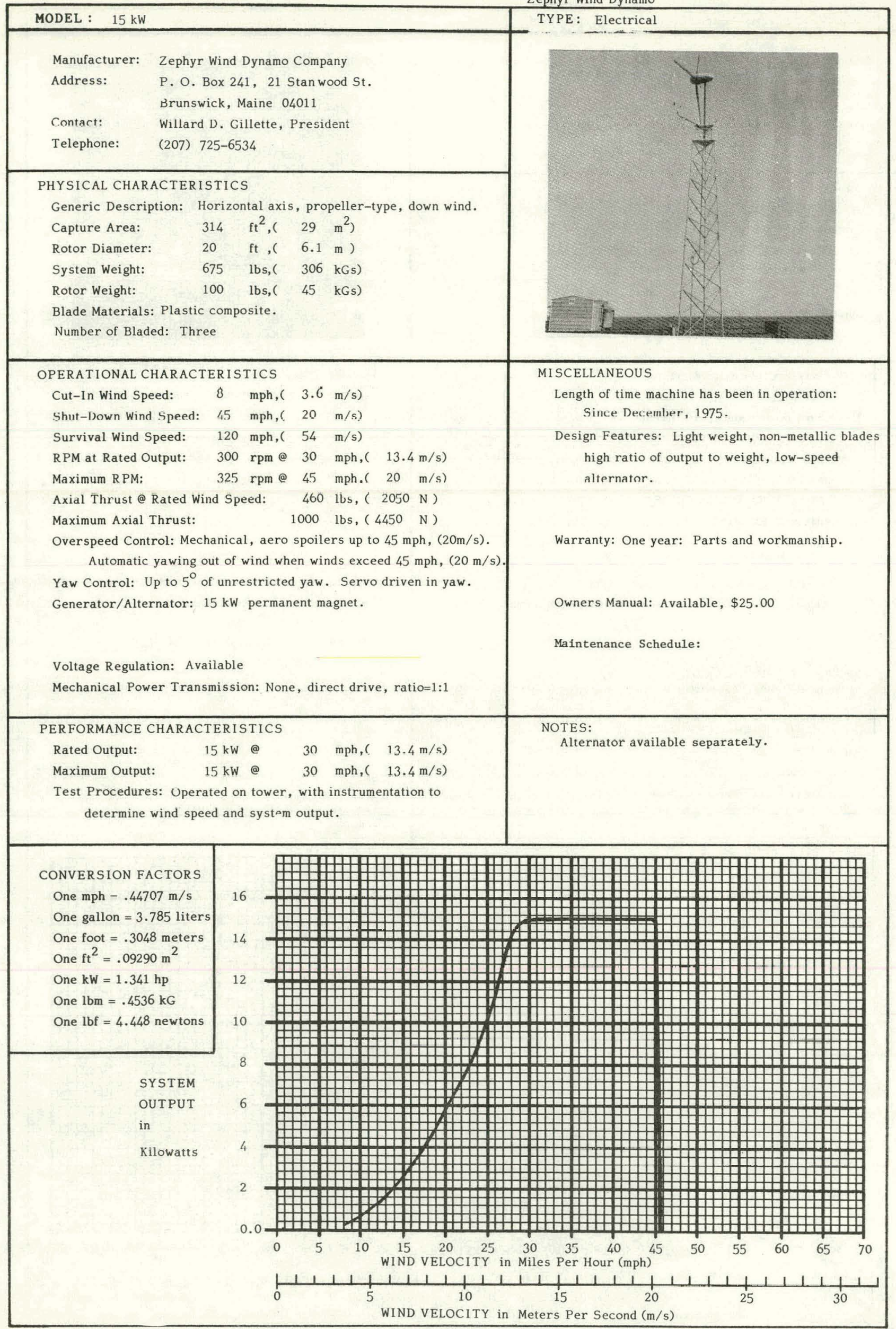




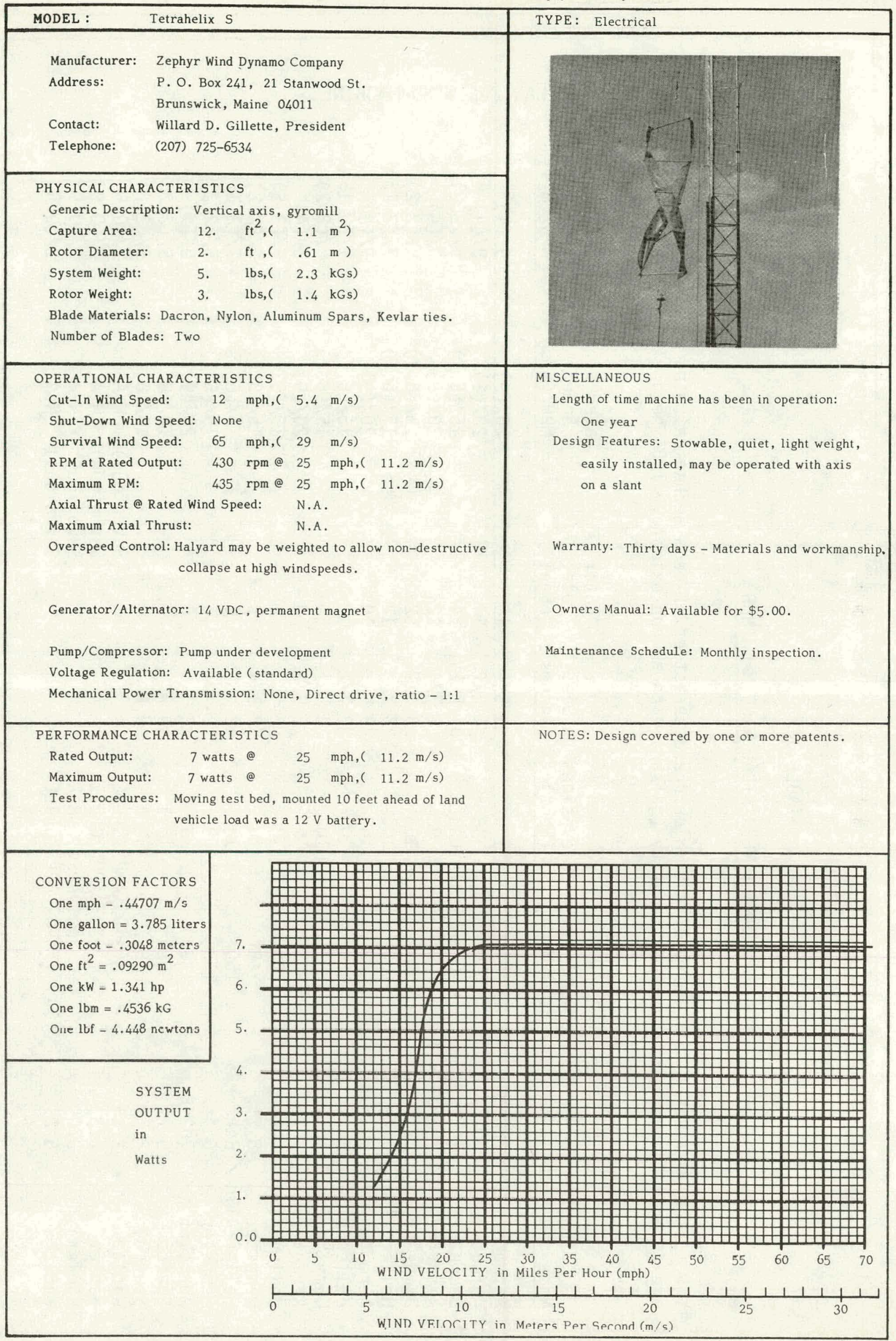


TABLE 3.2

\section{SUMMARY-MECHANICAL WIND MACHINES}

The following TABLE is a summary of the major characteristics of each mechanical wind machine. The data are arranged according to pumping capacity (gal/hr) with an approximately 100' head elevation.

\begin{tabular}{|c|c|c|c|c|c|c|c|}
\hline \multicolumn{2}{|l|}{ Name and Model } & $\begin{array}{l}\text { Capacity } \\
(\mathrm{Ga} 1 / \mathrm{Hr} \text {.) } \\
\end{array}$ & $\begin{array}{l}\text { Elevations } \\
\text { (Feet) }\end{array}$ & $\begin{array}{c}\text { Cyl. } \\
\text { Dia. } \\
-\quad \text { (Inches) } \\
\end{array}$ & $\begin{array}{l}\text { Rotor } \\
\text { Dia. } \\
\text { (Feet) }\end{array}$ & $\begin{array}{l}\text { Rated Wind } \\
\text { Speed } \\
M F H /(\mathrm{m} / \mathrm{s}) \\
\end{array}$ & $\begin{array}{c}\text { Cut-In Wind } \\
\text { Speed } \\
\mathrm{MPH} /(\mathrm{m} / \mathrm{s}) \\
\end{array}$ \\
\hline Aermotor & $702-16$ & 1,700 & 100 & $53 / 4$ & 15 & $20 /(9)$ & $9 /(4)$ \\
\hline Aermotor & $702-14$ & 1,050 & 98 & $41 / 2$ & 17 & $2 C /(9)$ & $9 /(4)$ \\
\hline Dempster & $14 \mathrm{ft}$. & NO DATA & AVAILABLE Q & $100^{\prime}$ ELEV. & 14 & $15 /(6.7)$ & $5 /(2.2)$ \\
\hline Aermotor & $702-12$ & 730 & 98 & $33 / 4$ & 12 & $2 \mathrm{C} /(9)$ & $9 /(4)$ \\
\hline Dempster & $12 \mathrm{ft}$ & 630 & 108 & $31 / 2$ & 12 & $15 /(6.7)$ & $5 /(2.2)$ \\
\hline Heller-Aller & Baker 12 & 600 & 100 & 3 & 12 & $15 /(6.7)$ & $7 /(3.15)$ \\
\hline Aermotor & $702-10$ & 470 & 100 & 3 & 10 & $20 /(9)$ & $9 /(4)$ \\
\hline Heller-Aller & Baker 10 & 460 & 100 & $21 / 2$ & 10 & $15 /(6.7)$ & $7 /(3.15)$ \\
\hline Dempster & $10 \mathrm{ft}$ & 357 & 102 & 3 & 10 & $15 /(6.7)$ & $5 /(2.2)$ \\
\hline Aermotor & $702-8$ & 325 & 94 & $21 / 2$ & 8 & $20 /(9)$ & $9 /(4)$ \\
\hline Heller-Aller & Baker-8 & 250 & 100 & 2 & 8 & $15 /(6.7)$ & $7 /(3.5)$ \\
\hline Dempster & $8 \mathrm{ft}$. & 248 & 107 & $21 / 4$ & 8 & $15 /(6.7)$ & $5 /(2.2)$ \\
\hline Heller-Aller & Baker-6 & 150 & 100 & 2 & 6 & $15 /(6.7)$ & $7 /(3.15)$ \\
\hline Dempster & $6 \mathrm{ft}$. & 130 & 95 & 2 & 6 & $15 /(6.7)$ & $5 /(2.2)$ \\
\hline Aermotor & $702-6$ & 130 & 95 & 2 & 6 & $20 /(9)$ & $9 /(4)$ \\
\hline Sparco & D & 58 & 13.1 & N.A. & 4. 17 & $18 /(8)$ & $5 /(2.2)$ \\
\hline Sparco & $P$ & 58 & 32.8 & N.A. & 4.17 & $18 /(8)$ & $5 /(2.2)$ \\
\hline Wadler & 271 & NOT & APPLICAB_E & & (Savonious) & N.A. & $2 /(0.9)$ \\
\hline Wadler & 273 & NOT & APPLICAB_E & & (Savonious) & N. A. & $2 /(0.9)$ \\
\hline Wadler & 370 & NOT & APPLICAB E & & (Savonious) & N. A. & $2 /(0.9)$ \\
\hline Wadler & 672 & NOT & APPLIC.ABLE & & (Savonisus) & N. A. & $2 /(0.9)$ \\
\hline
\end{tabular}




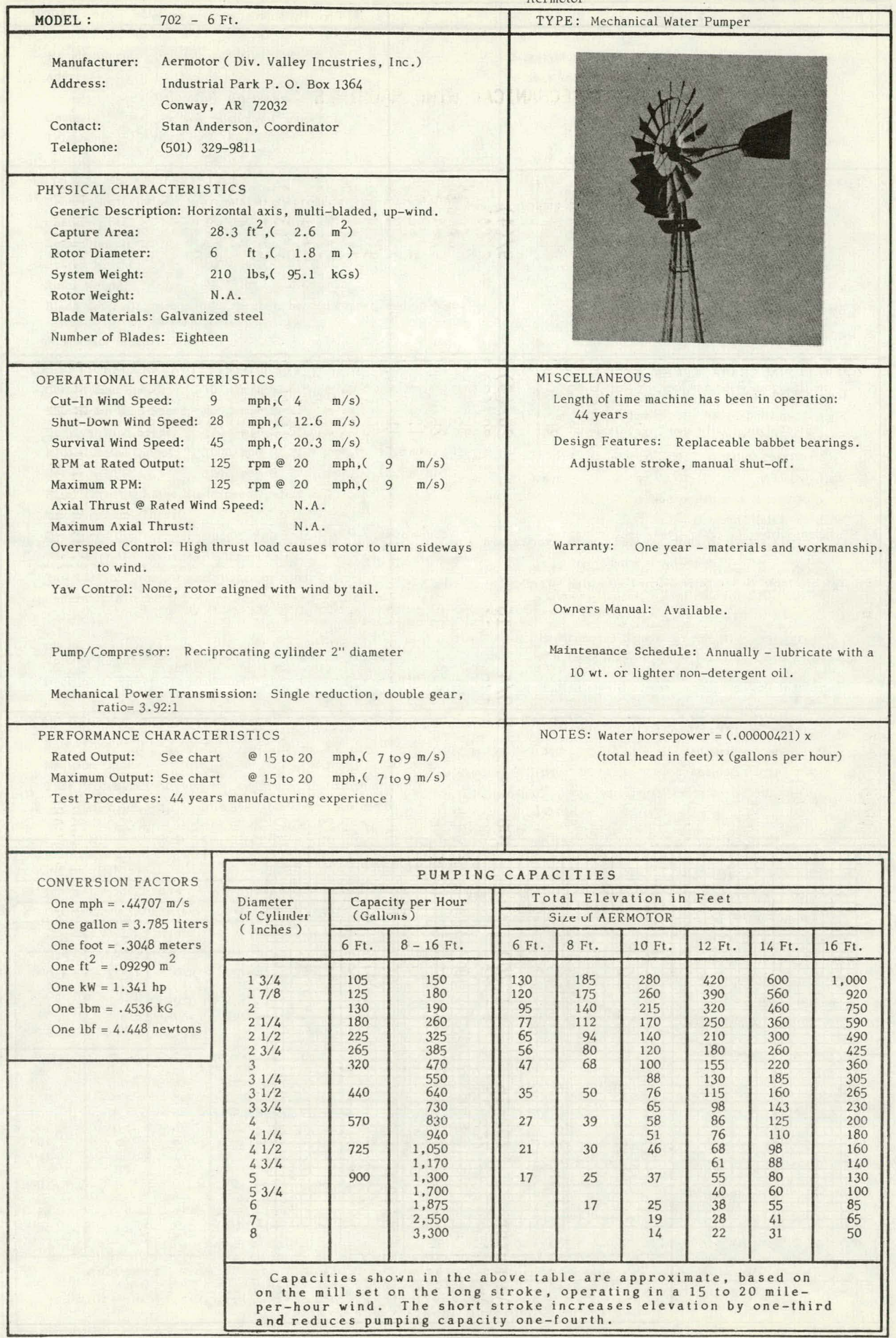




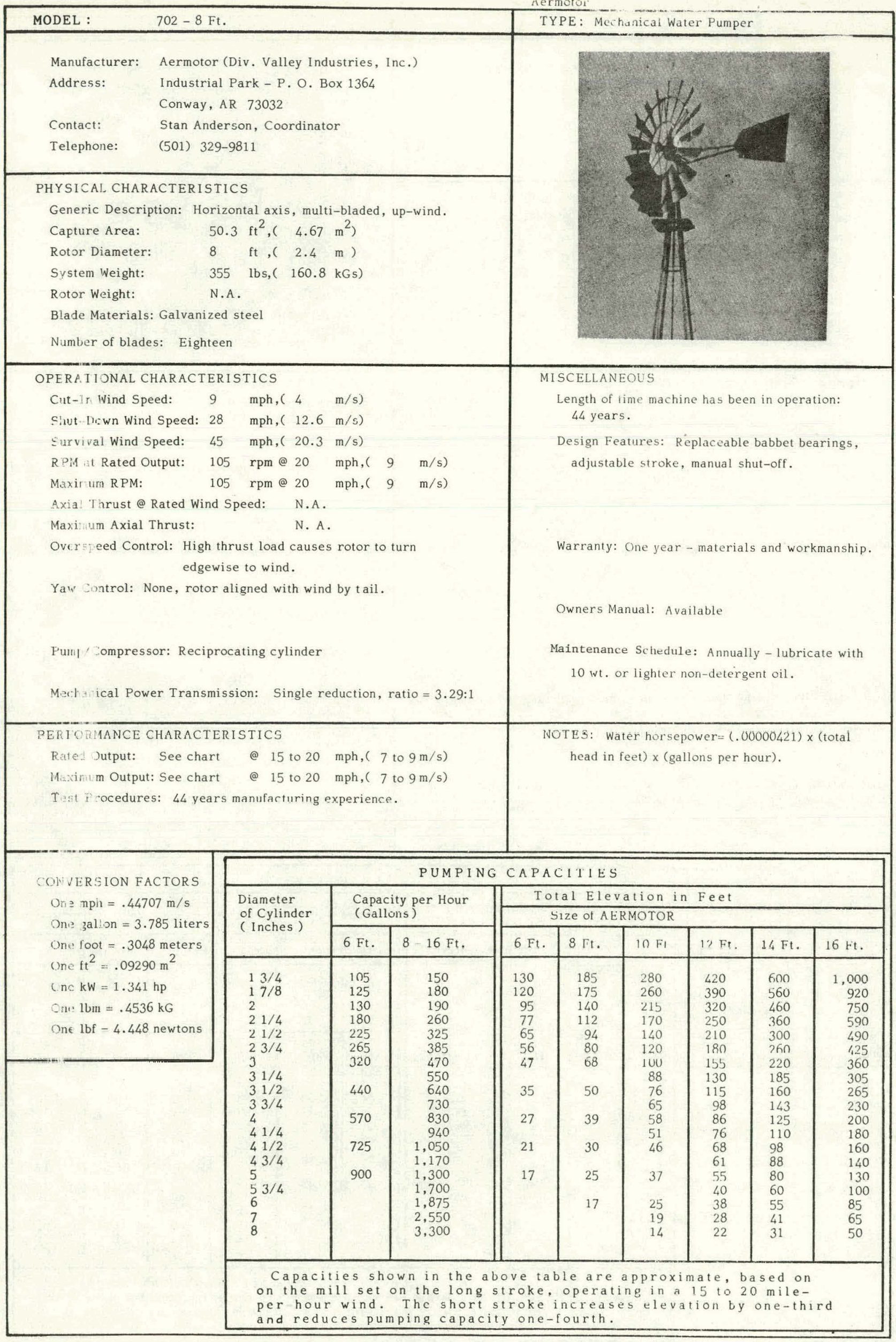




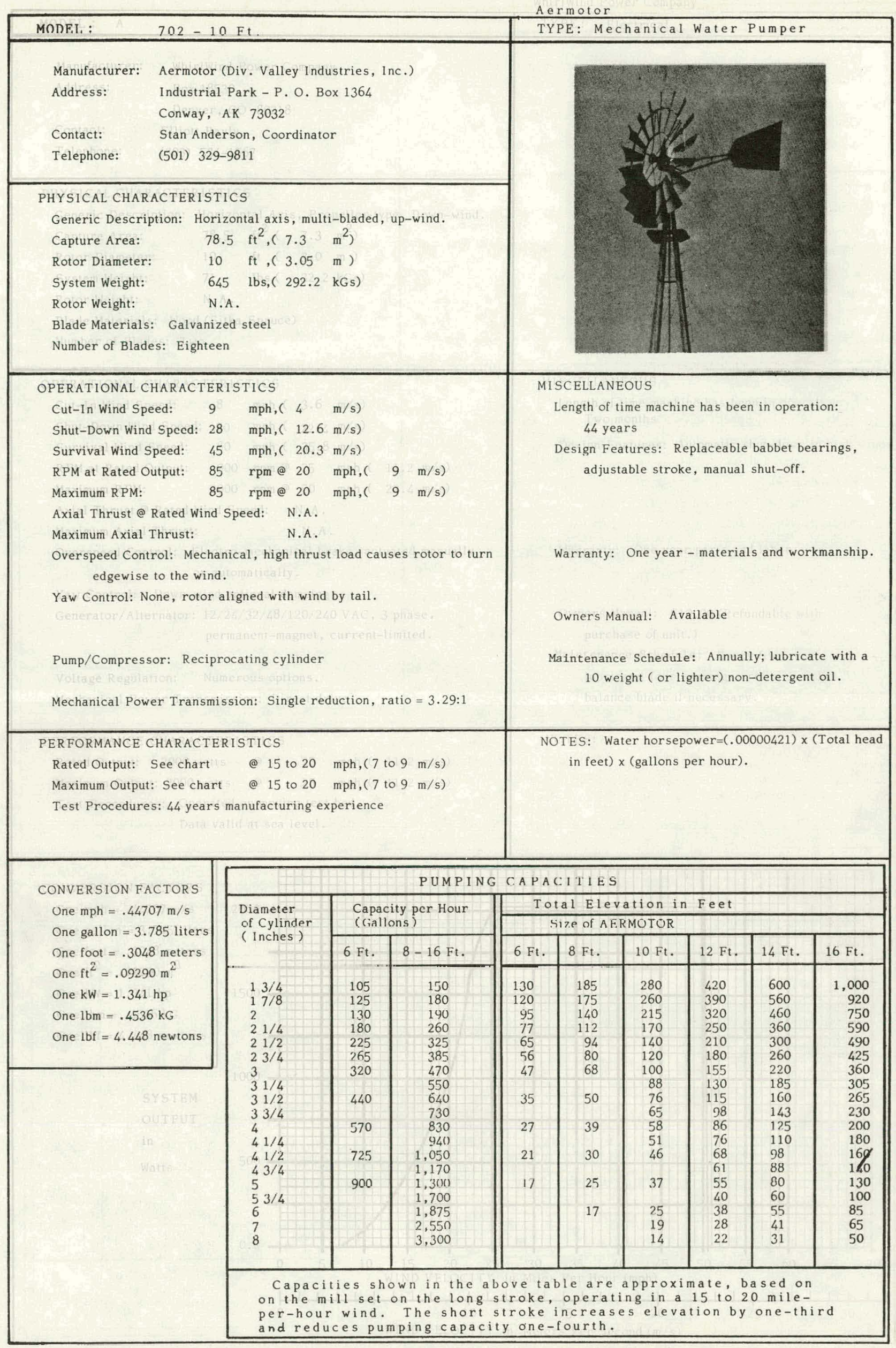




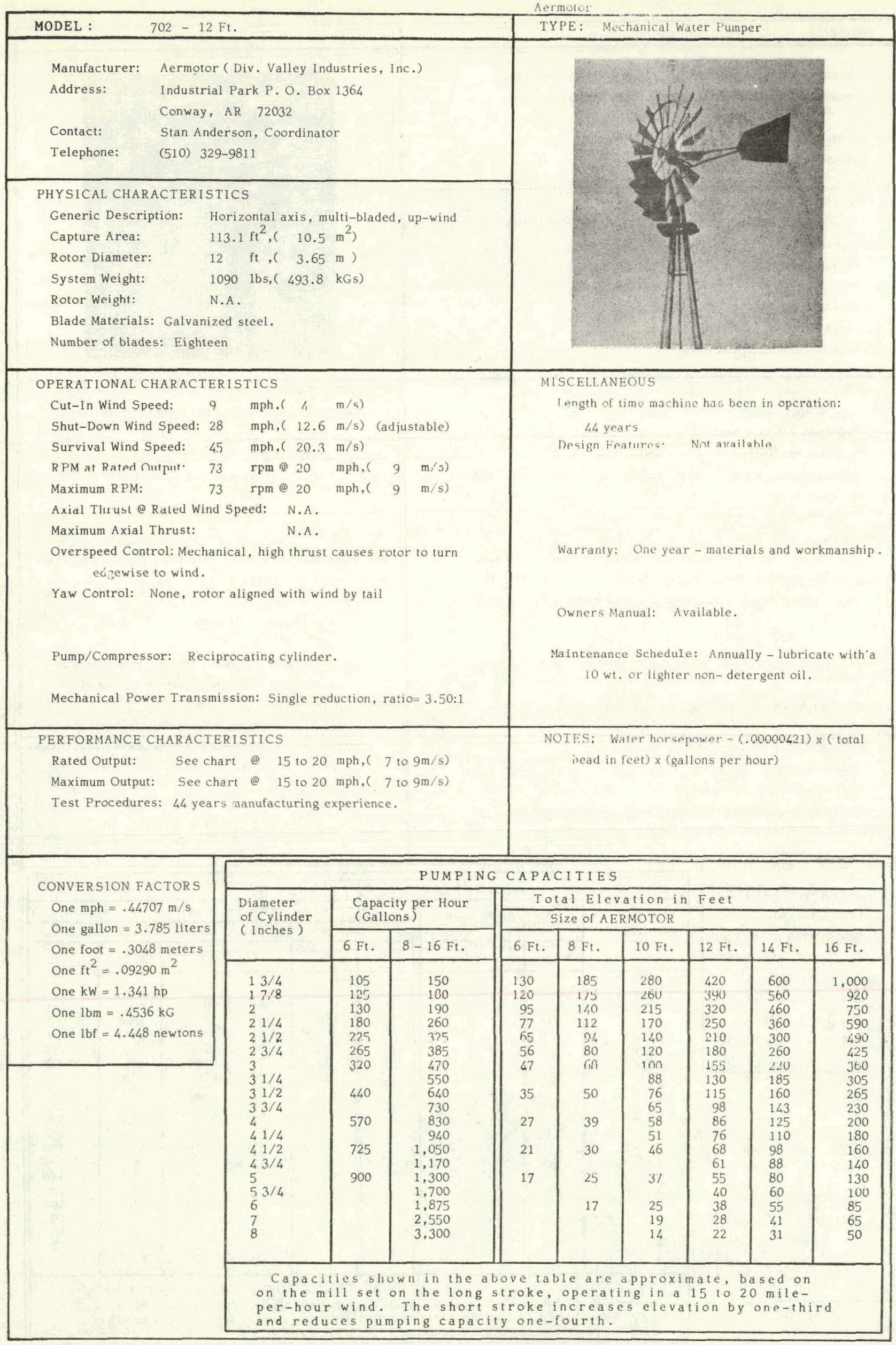




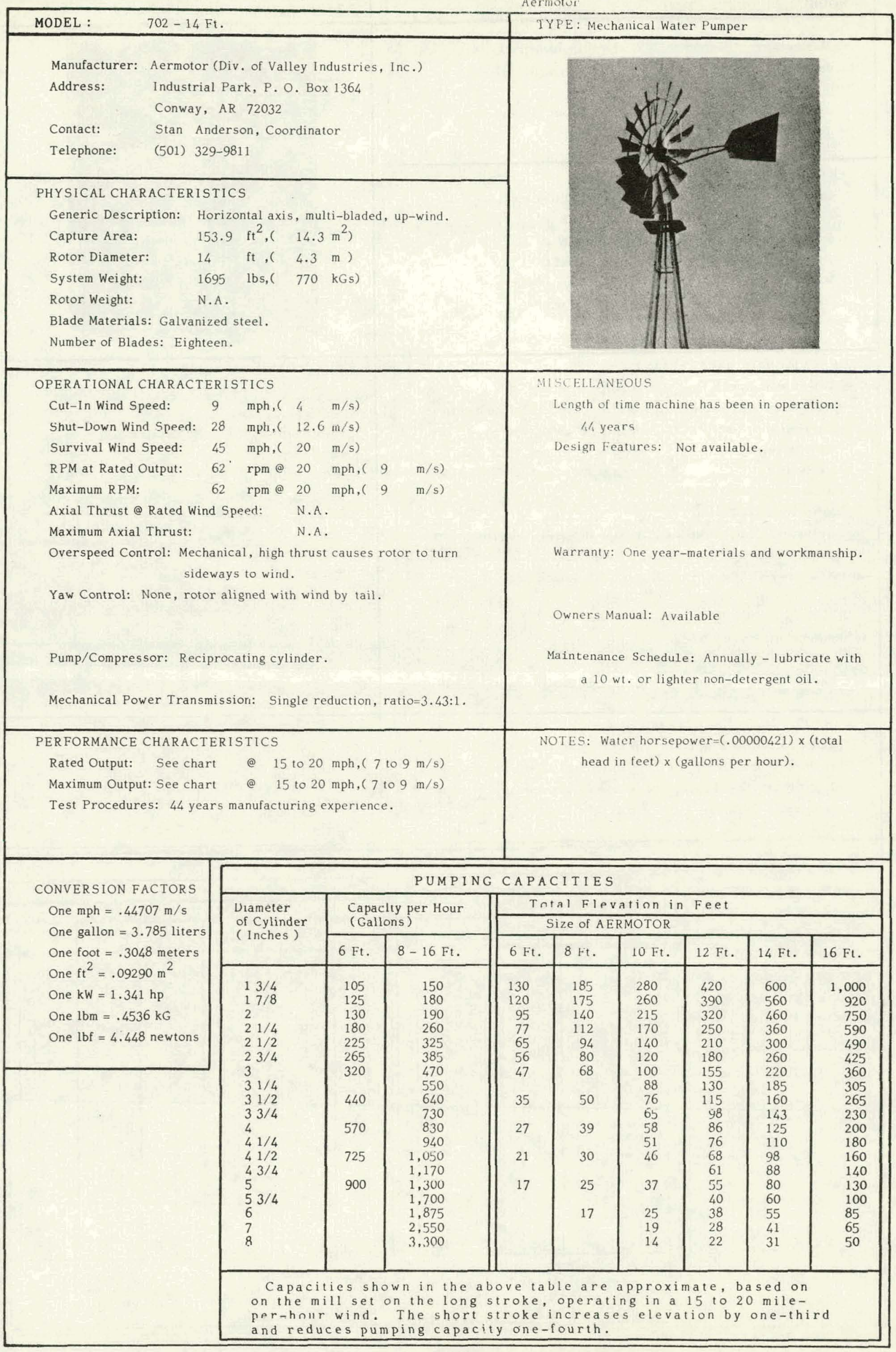




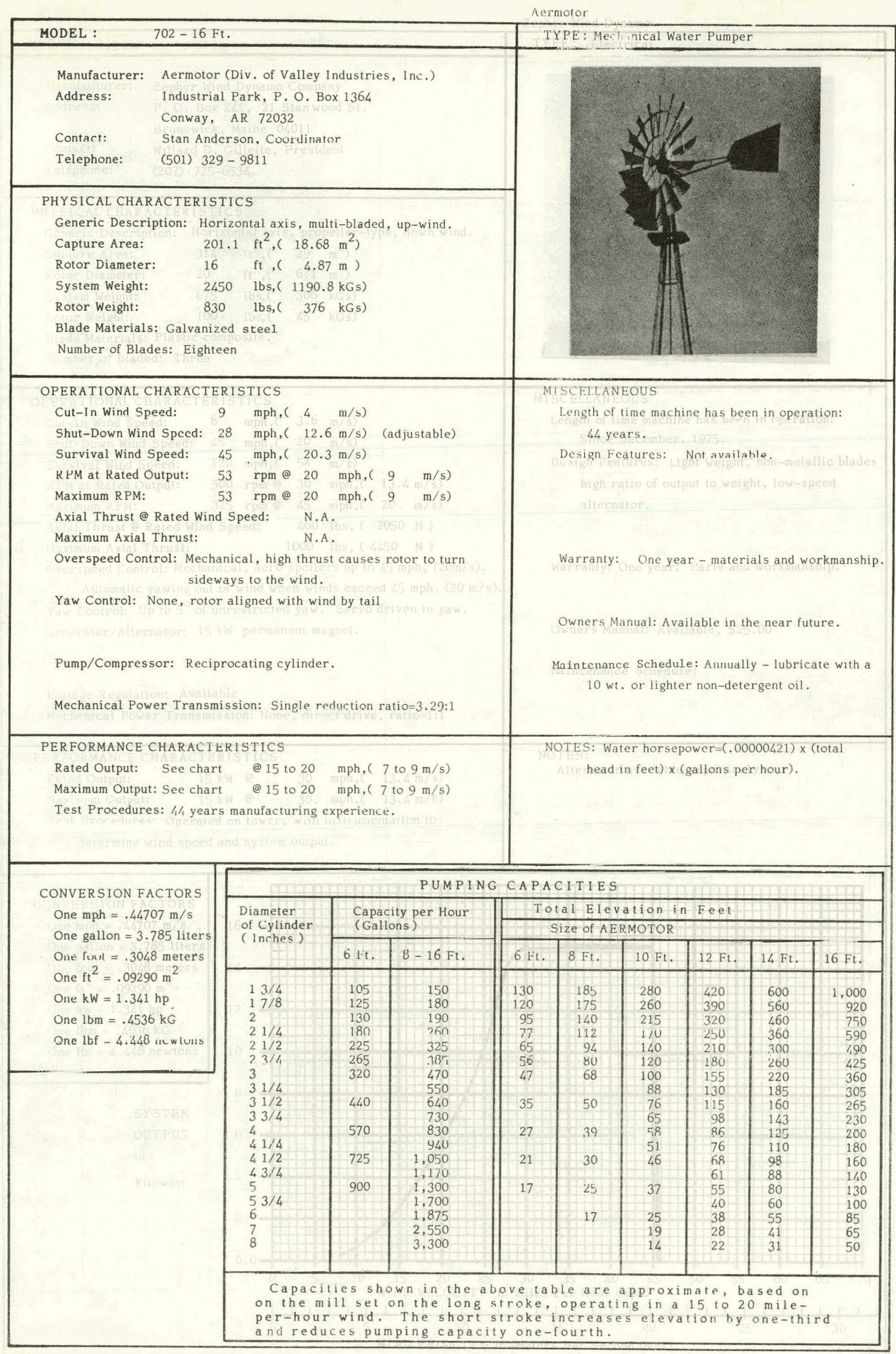




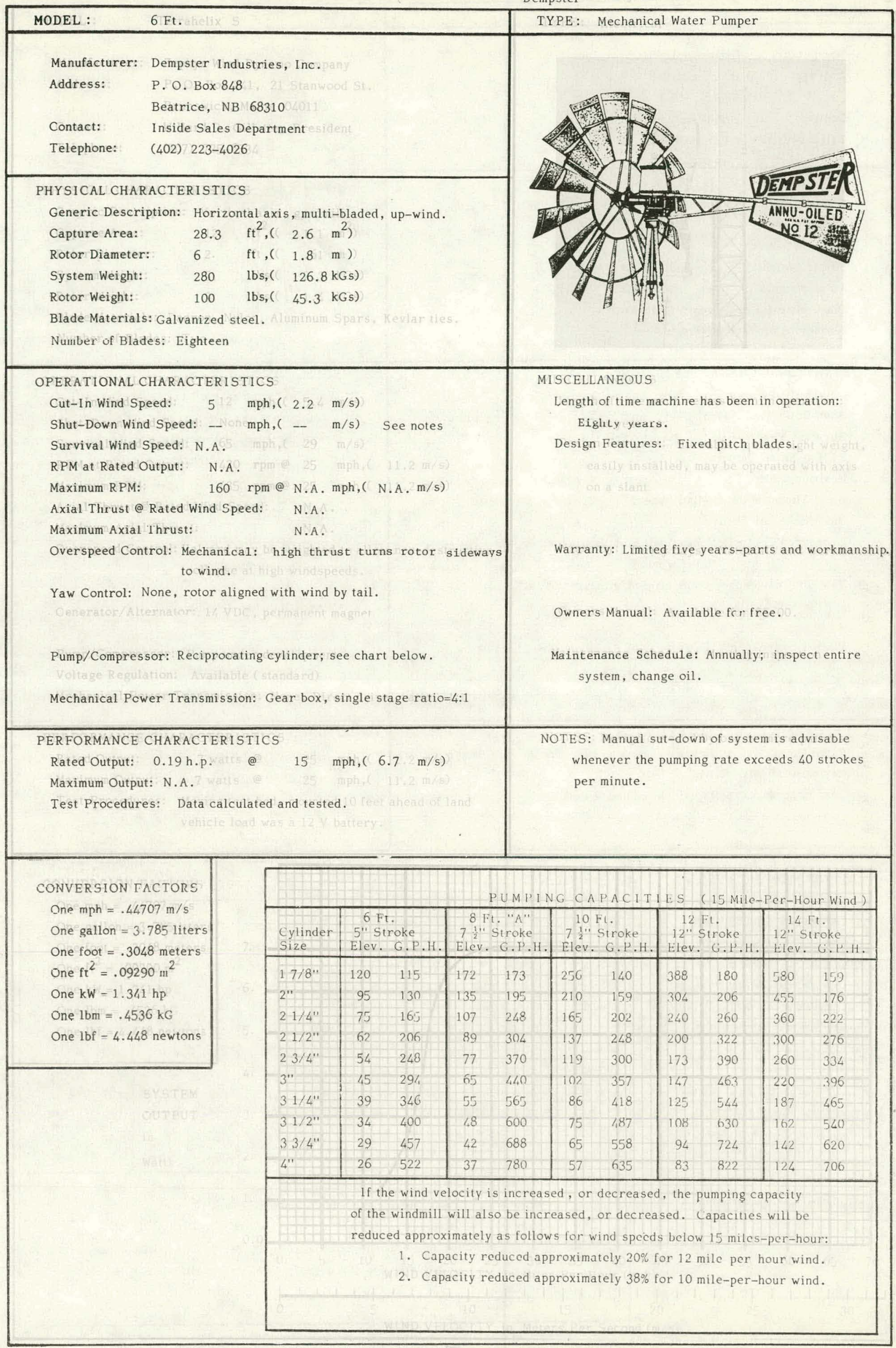




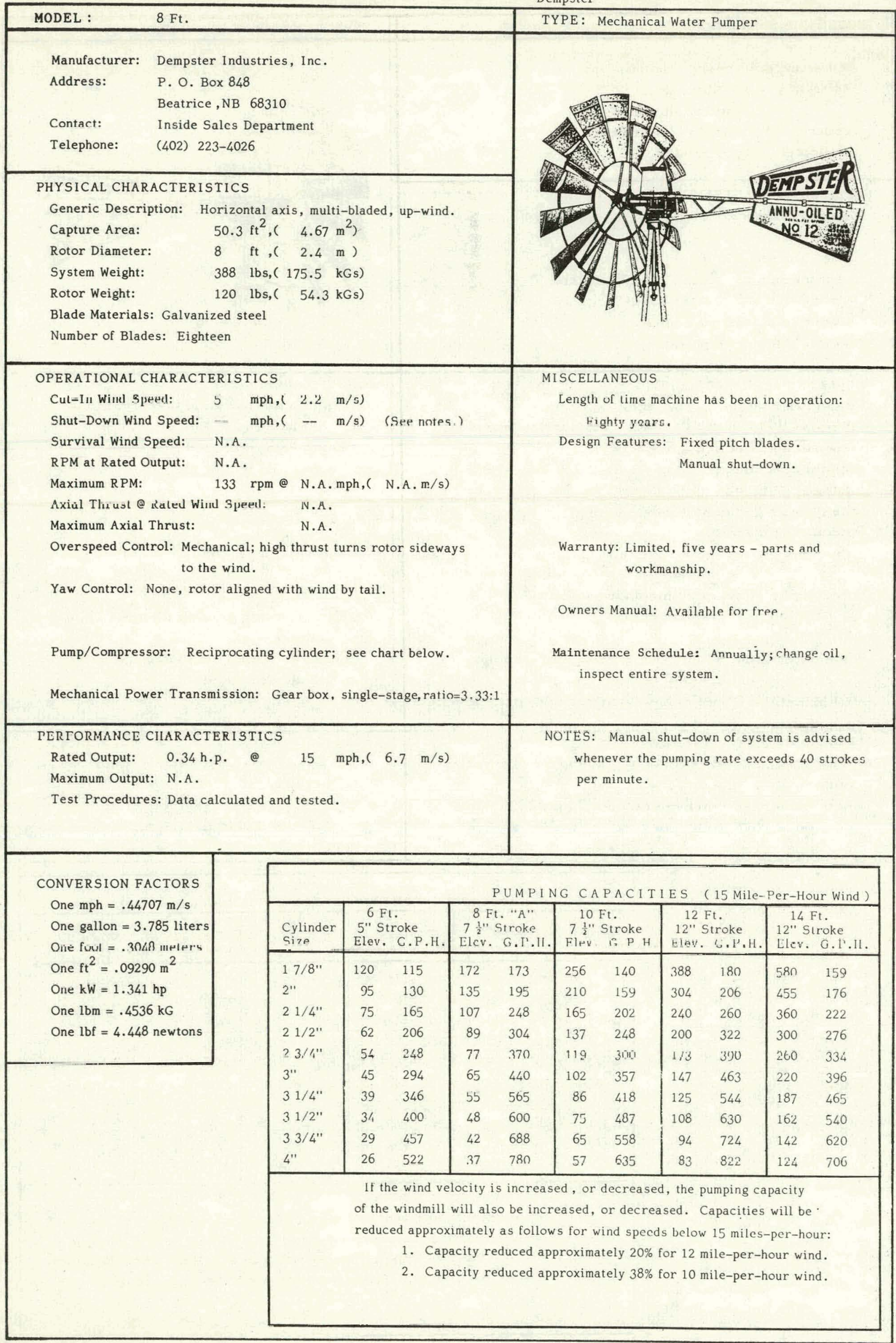




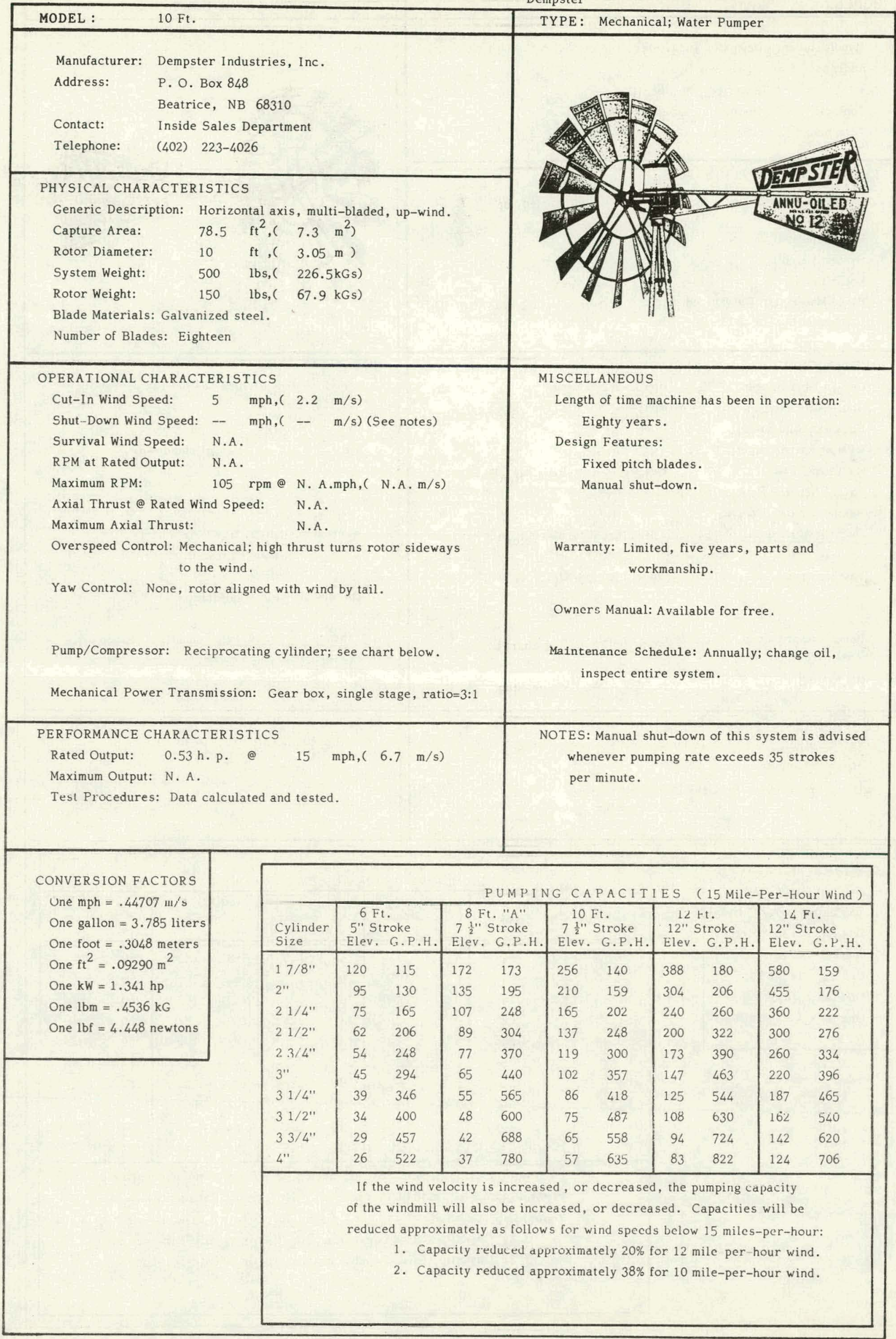




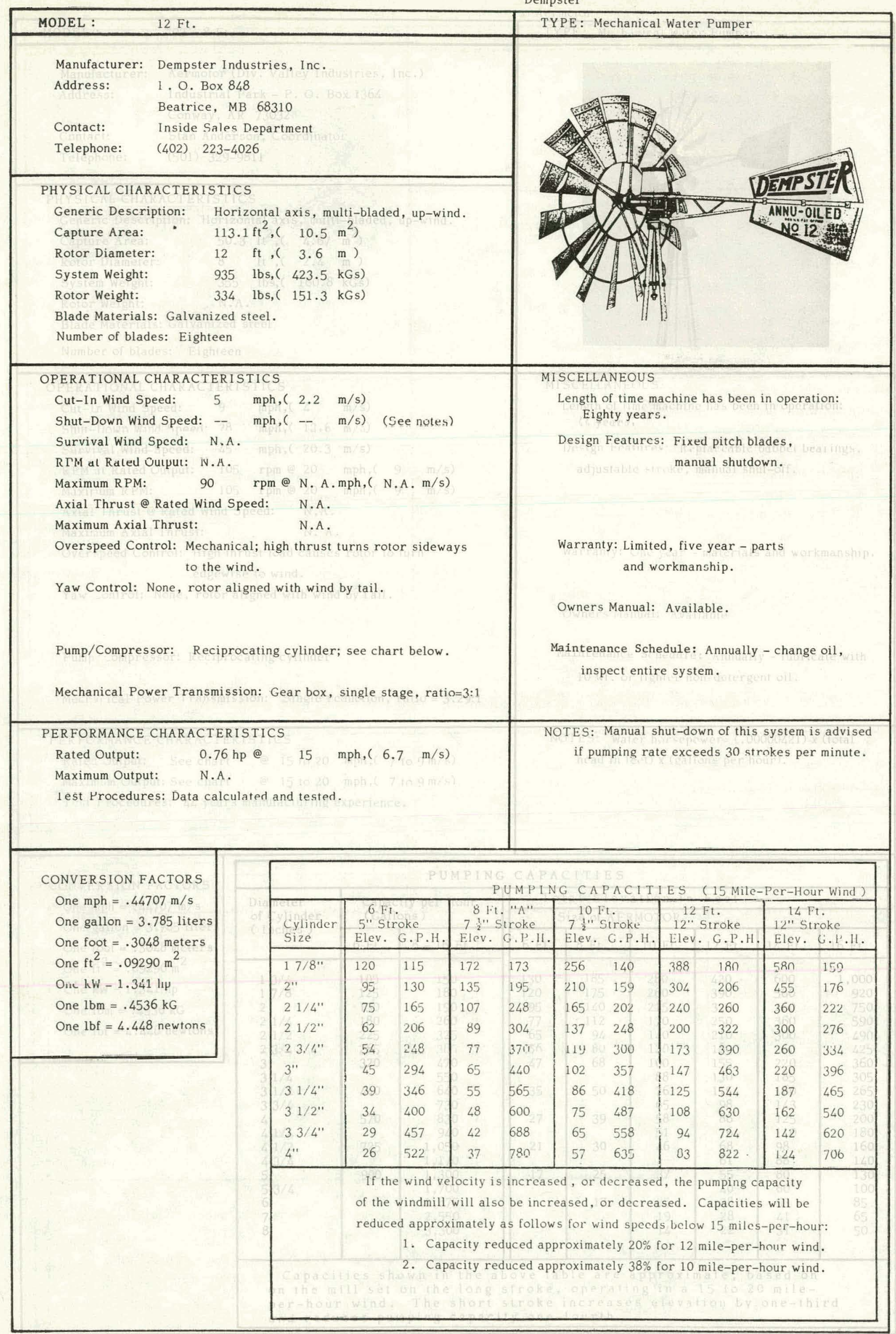




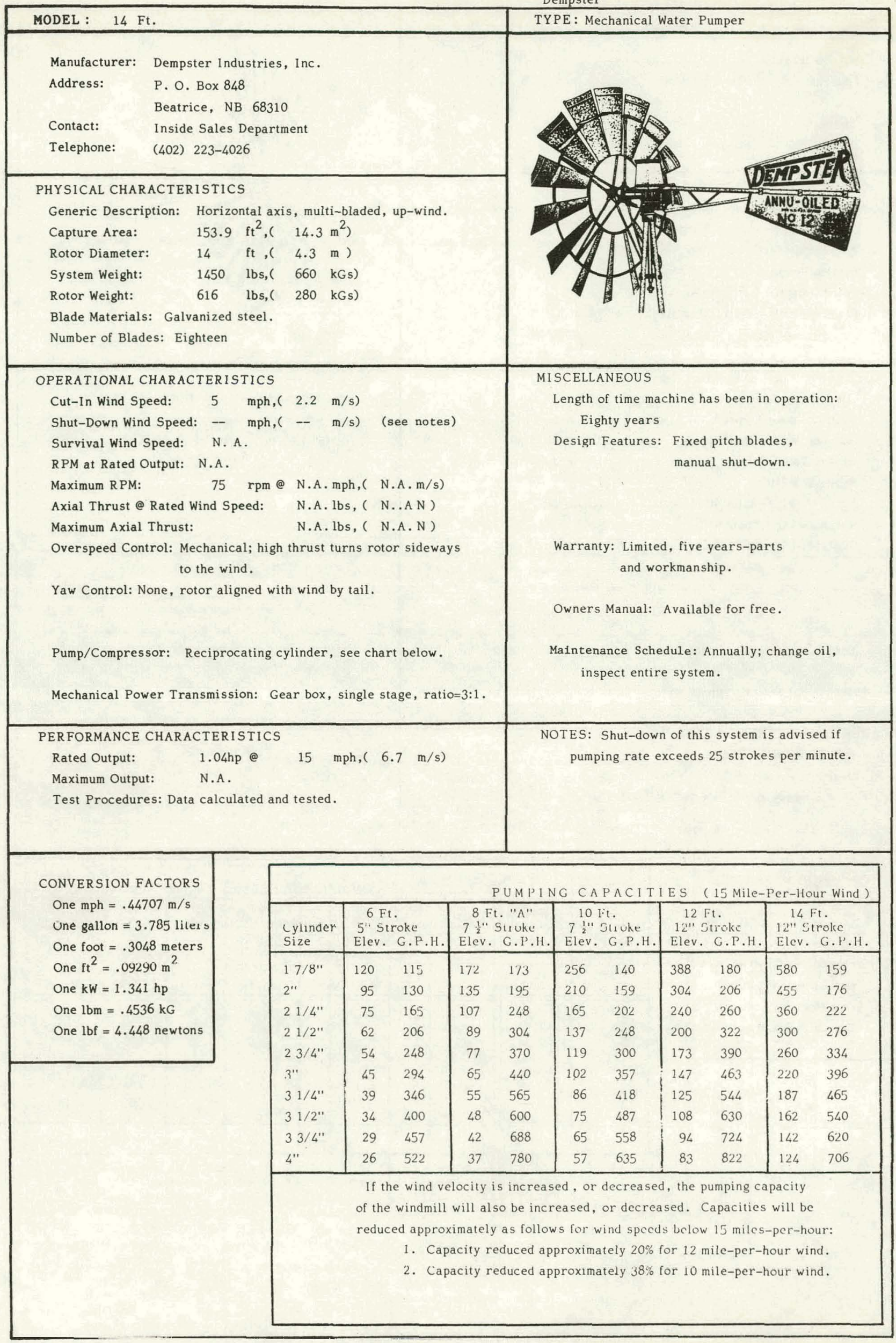


Manufacturer: Heller-Aller Company

Address: Perry \& nakwood St. Napoleon, OH 43545

Contact: James Bradner or Charles Buehrer

Telephone: (419) $59 \%-1856$

PHYSICAL CHARACTERISTICS

Generic Description: Horizontal axis, multi-bladed, up-wind.

Capture Area:

$28.3 \mathrm{ft}^{2},\left(\quad 2.6 \mathrm{~m}^{2}\right)$

Rotor Diameter:

$6 \mathrm{ft},(1.8 \mathrm{~m})$

System Weight:

220 lbs, ( $99.6 \mathrm{kGs})$

Rotor Weight:

N.A.

Blade Materials: Galvanized steel - 18 gauge

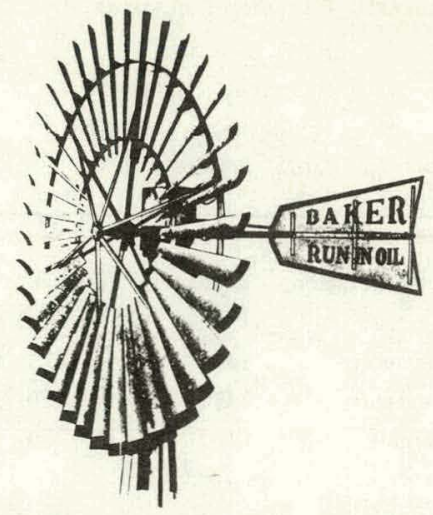

OPERATIONAL CHARACTERISTICS

rut-In Wind speed. $7 \mathrm{mph},(3.15 \mathrm{~m} / \mathrm{s})$

Shut-Down Wind Speed: $25 \mathrm{mph},(11.2 \mathrm{~m} / \mathrm{s})$

Survival Wind Speed: $\quad 70 \mathrm{mph} .(31.5 \mathrm{~m} / \mathrm{s})$

RPM at Rated Output: $150 \mathrm{rpm}$ (e) $15 \mathrm{mph},(6.7 \mathrm{~m} / \mathrm{s})$

Maximum RPM: $\quad$ N.A.

Axial Thrust @ Rated Wind Speed: N.A.

Maximum Axial Thrust: N.A.

Overspeed Control: Mechanical: high thrust causes rotor to turn sideways to the wind.

Yaw Control: None, rotor aligned with wind by tail.

Pump/Compressor: Water pump, cylinder type.

Mechanical Power Transmission: Gear box, single stage rato=4:1

MISCELLANEOUS

Length of time machine has been in operation: Fifty years.

Design Features. Fixad blade pitch, manual sliut-duwil.

Warranty: One year - parts and workmanship.

Owners Manual: Only descriptive literature available.

Maintenance Schedule: Annually: inspect entire system, change oil.

PERFORMANCE CHARACTERISTICS

Rated Output: N.A.

Maximum Output: N.A.

Test Procedures: Not available

CONVERSION FACTORS

One $\mathrm{mph}=.44707 \mathrm{~m} / \mathrm{s}$

One gallon $=3.785$ liters

One foot $=.3048$ meters

One $\mathrm{ft}^{2}=.09290 \mathrm{~m}^{2}$

nne $\mathrm{kW}=1.3 / 1 \mathrm{hp}$

One $\mathrm{lbm}=.4536 \mathrm{kG}$

One $\mathrm{lbf}=4.448$ newtons

\begin{tabular}{|c|c|c|c|c|c|c|c|c|}
\hline \multirow[b]{3}{*}{$\begin{array}{l}\text { Total } \\
\text { Elevation } \\
\text { in Feet }\end{array}$} & \multicolumn{8}{|c|}{$\begin{array}{l}\text { P UM P ING CA PACI T I ES } \\
\text { (In a 15-mile-per-hour wind) }\end{array}$} \\
\hline & \multicolumn{2}{|c|}{6 Foot Baker } & \multicolumn{2}{|c|}{8 Foot Baker } & \multicolumn{2}{|c|}{10 Foot Baker } & \multicolumn{2}{|c|}{12 Foot Baker } \\
\hline & $\begin{array}{l}\text { Diameter } \\
\text { of } \\
\text { Cylinder } \\
\text { (Inrhes) }\end{array}$ & $\begin{array}{l}\text { U.S. } \\
\text { Gallons } \\
\text { Per } \\
\text { Hour } \\
\end{array}$ & $\begin{array}{l}\text { Diameter } \\
\text { of } \\
\text { Cylinder } \\
\text { (Inches) }\end{array}$ & $\begin{array}{l}\text { U.S. } \\
\text { Gallons } \\
\text { Per } \\
\text { Hour }\end{array}$ & $\begin{array}{l}\text { Diameter } \\
\text { of } \\
\text { Cylinder } \\
\text { (Inches) }\end{array}$ & $\begin{array}{l}\text { II. S. } \\
\text { Gallons } \\
\text { Per } \\
\text { Ilsur } \\
\end{array}$ & $\begin{array}{l}\text { Diameter } \\
\text { of } \\
\text { Cylinder } \\
\text { (Inclics) }\end{array}$ & $\begin{array}{l}\text { II S. } \\
\text { Gallons } \\
\text { Per } \\
\text { Iluus }\end{array}$ \\
\hline $\begin{array}{r}25 \\
35 \\
50 \\
75 \\
100 \\
125 \\
150 \\
200 \\
250 \\
300\end{array}$ & $\begin{array}{l}3 \\
21 / 2 \\
21 / 4 \\
2 \\
2 \\
15 / 8\end{array}$ & $\begin{array}{l}350 \\
240 \\
200 \\
160 \\
150 \\
120\end{array}$ & $\begin{array}{ll}3 & 1 / 2 \\
3 & \\
2 & 1 / 2 \\
2 & 1 / 4 \\
2 & \\
1 & 7 / 8 \\
1 & 3 / 4\end{array}$ & $\begin{array}{l}900 \\
720 \\
450 \\
35 n \\
250 \\
240 \\
220\end{array}$ & $\begin{array}{ll}4 & \\
3 & 1 / 2 \\
3 & \\
2 & 1 / 2 \\
2 & 1 / 2 \\
2 & \\
2 & \\
1 & 7 / 8 \\
1 & 3 / 4\end{array}$ & $\begin{array}{c}1250 \\
925 \\
700 \\
175 \\
460 \\
280 \\
280 \\
260 \\
215\end{array}$ & 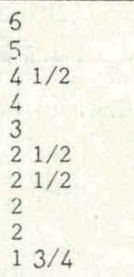 & $\begin{array}{l}2400 \\
1625 \\
1425 \\
1125 \\
600 \\
525 \\
525 \\
325 \\
325 \\
200\end{array}$ \\
\hline
\end{tabular}

The above capacities are approximate. By the total elevation in feet, we do not mean the depth of the well, but the distance to the cylinder. Do not use pipe smaller than that for which cylinders are fitted.

While we recommend the above table, larger cylinders may in many circumstances be used with satisfaction. 


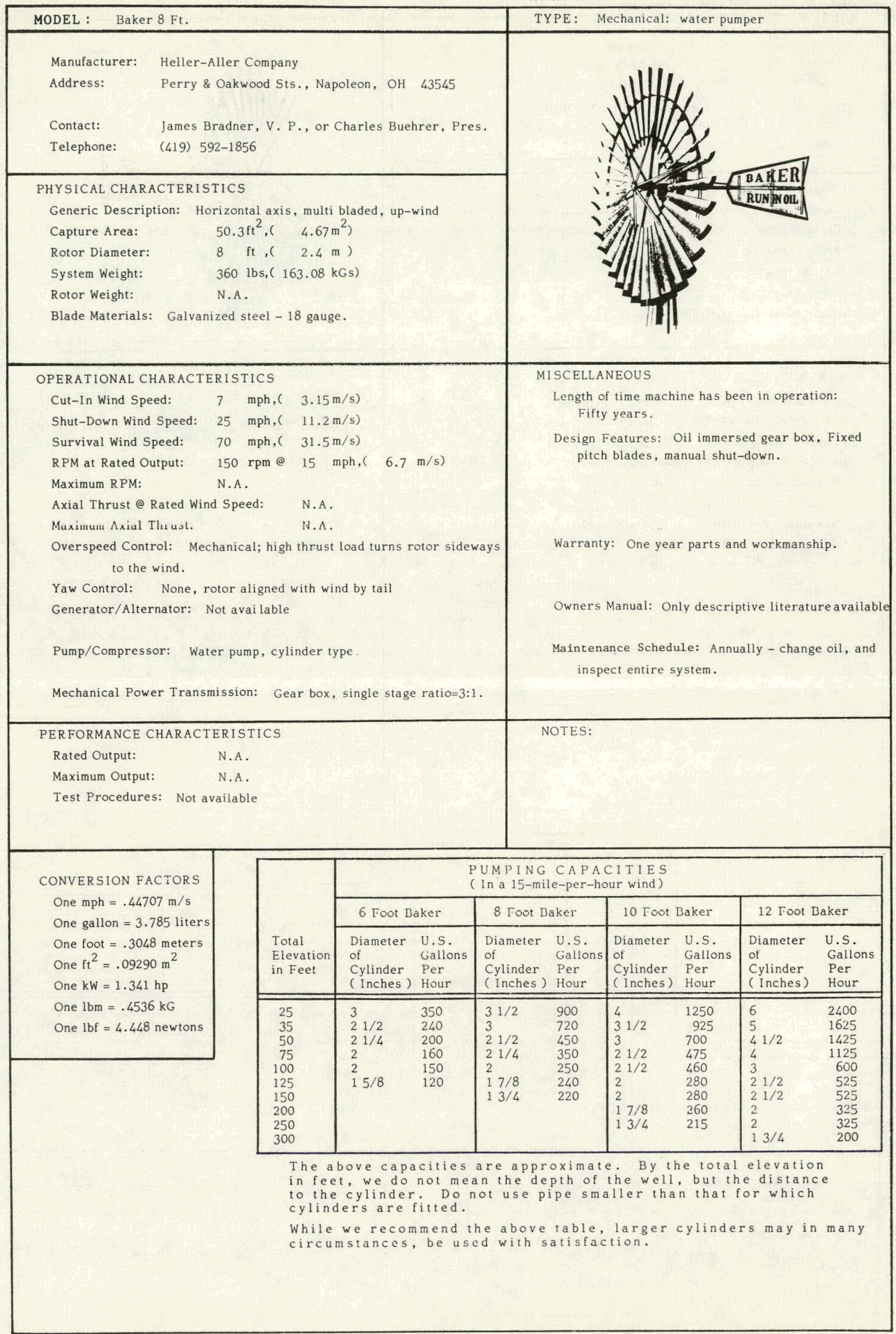




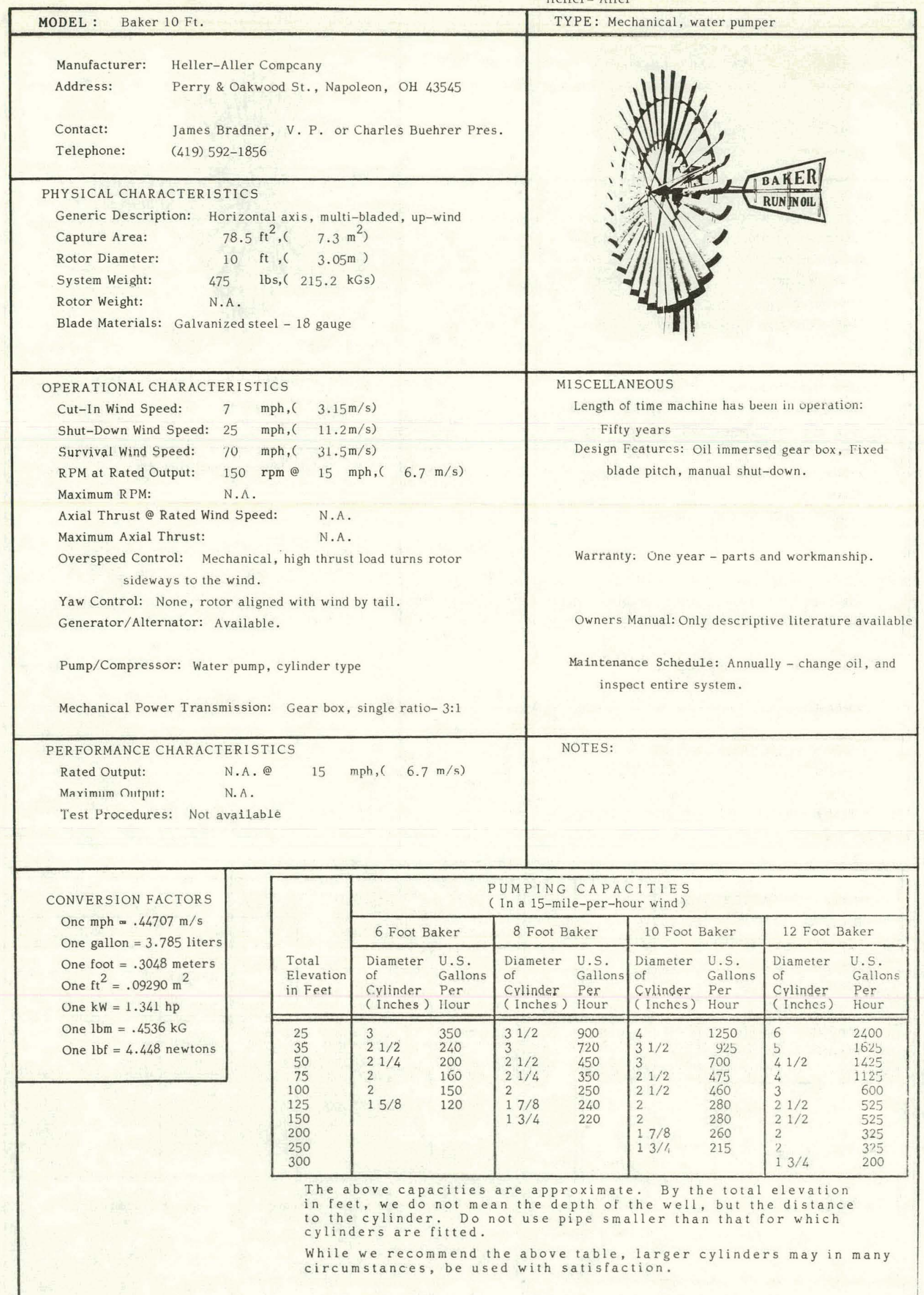




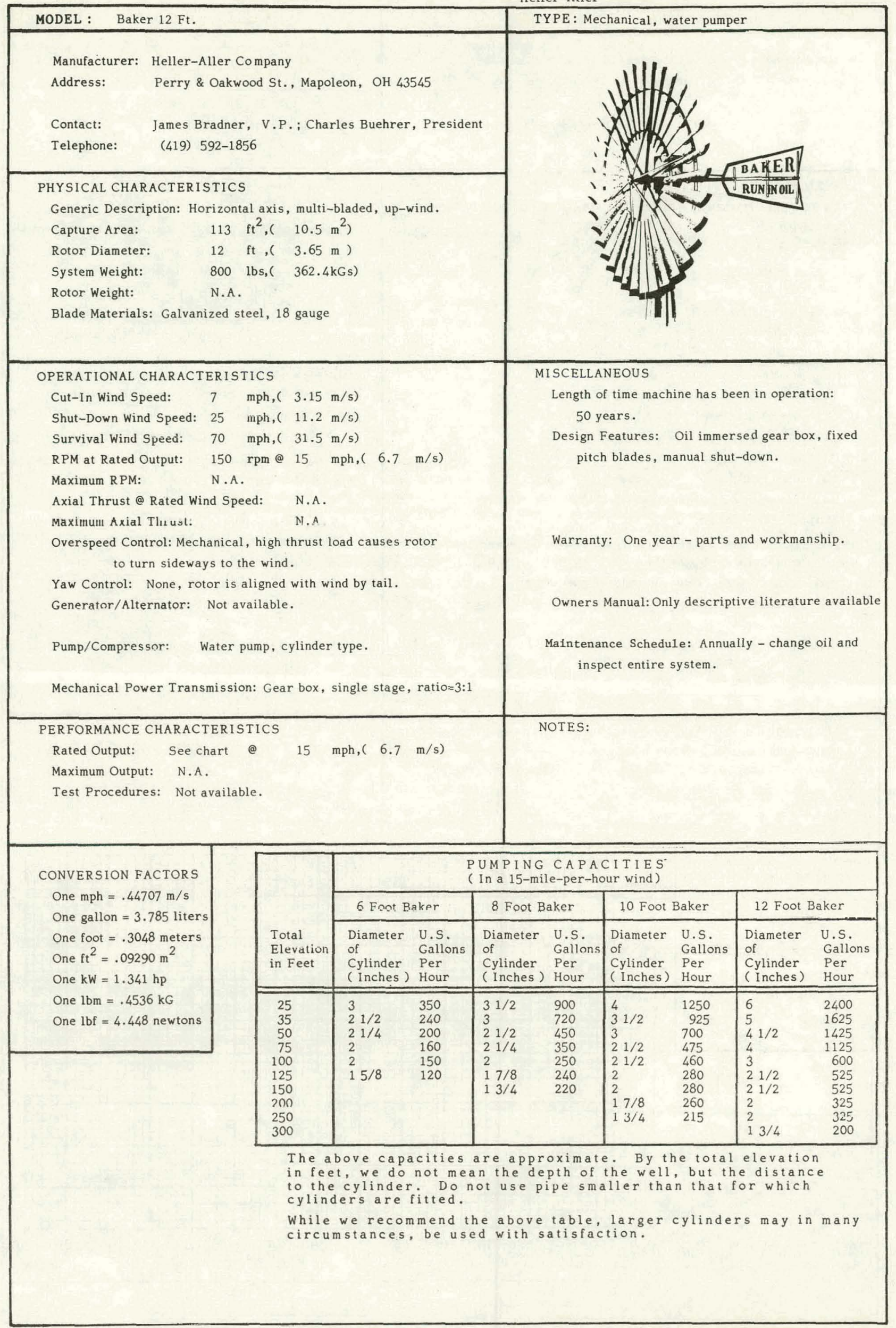




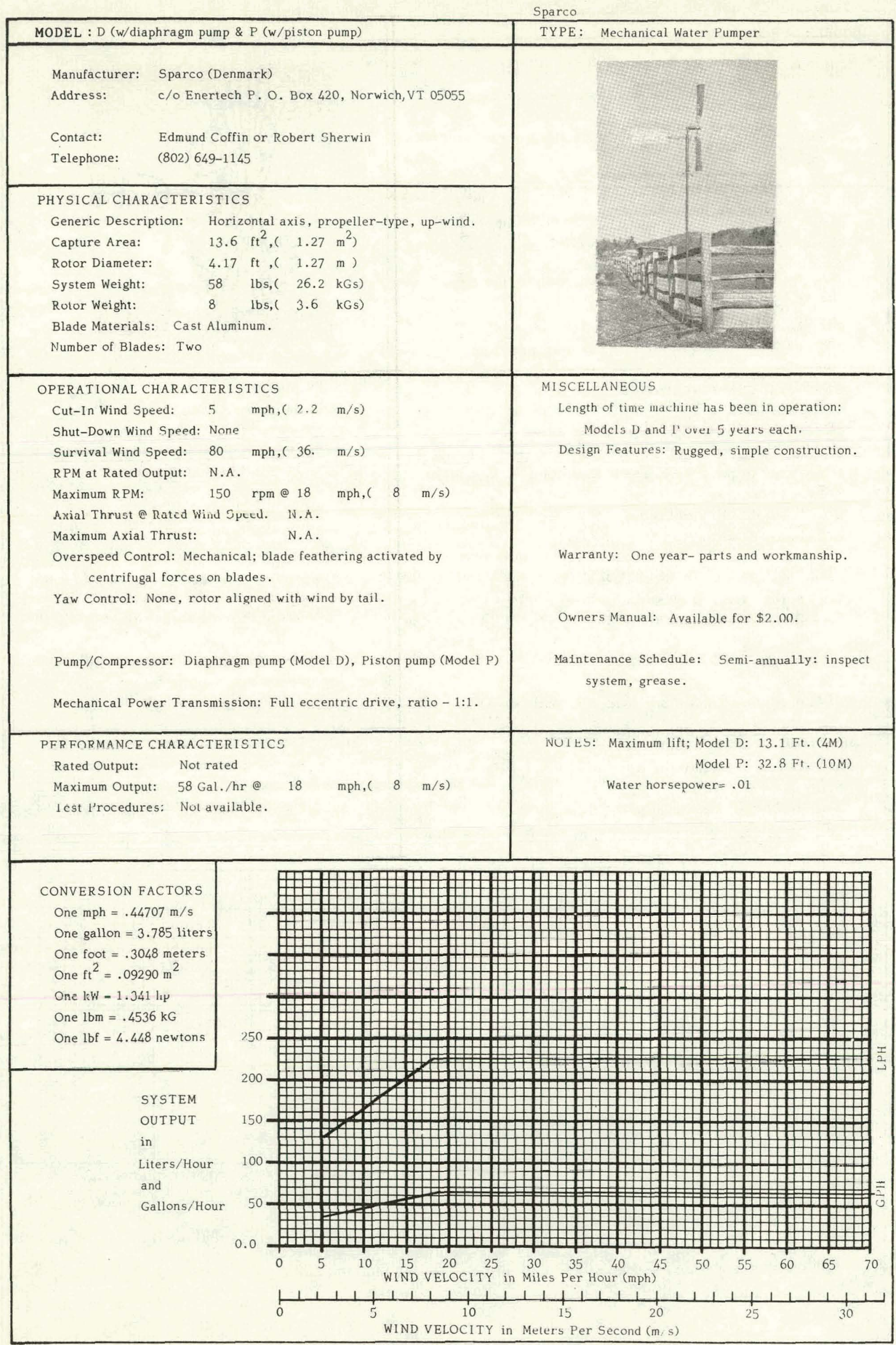




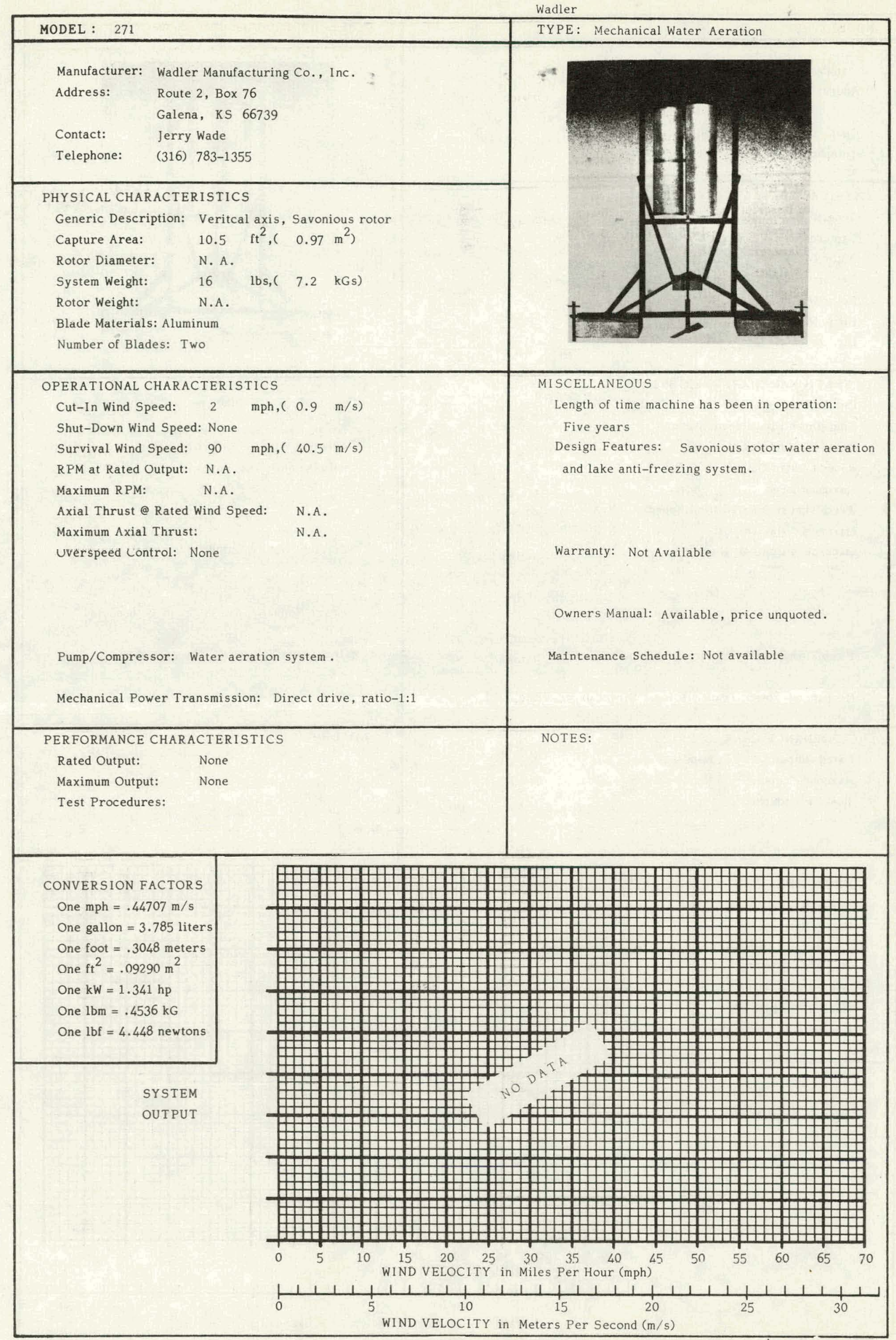




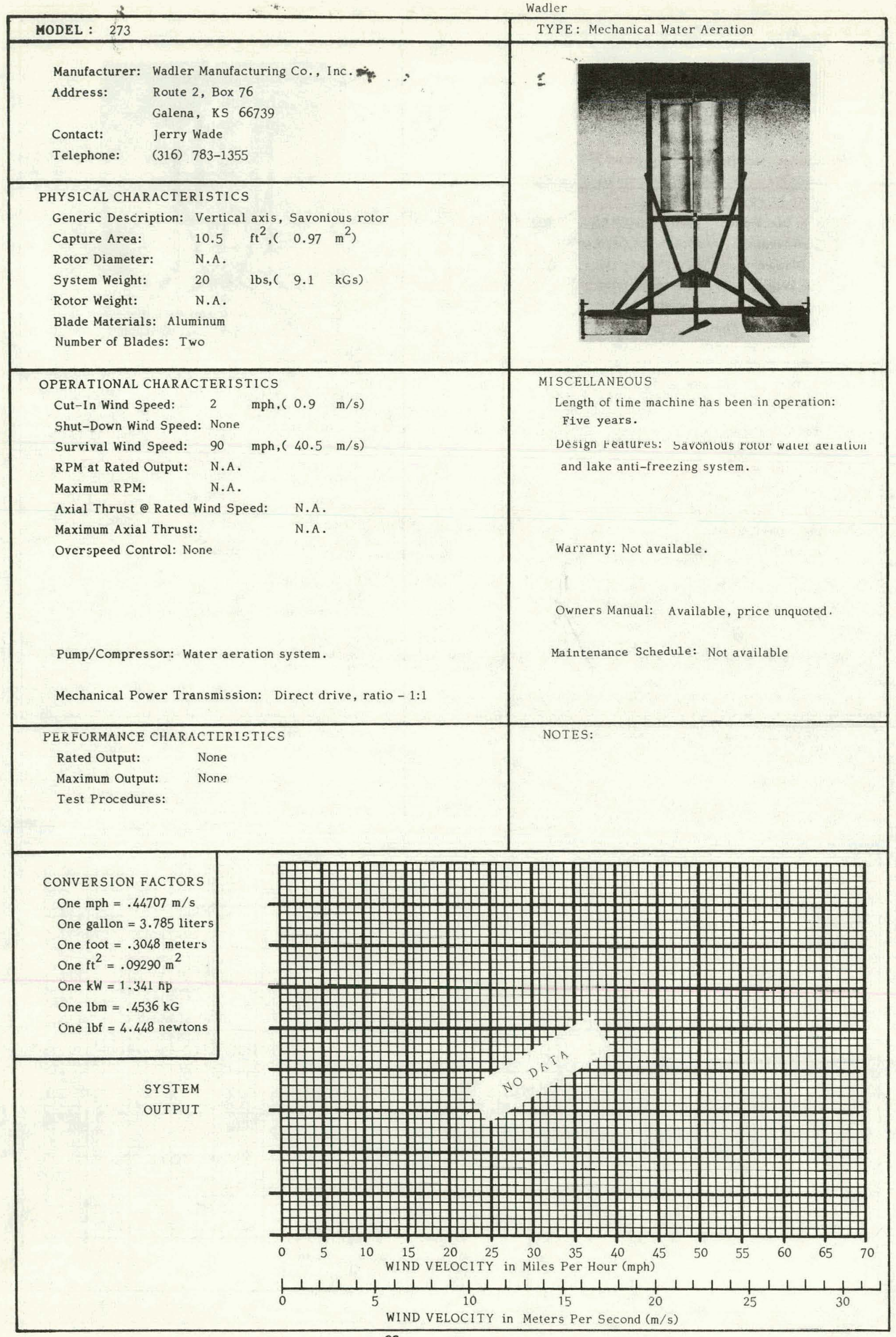




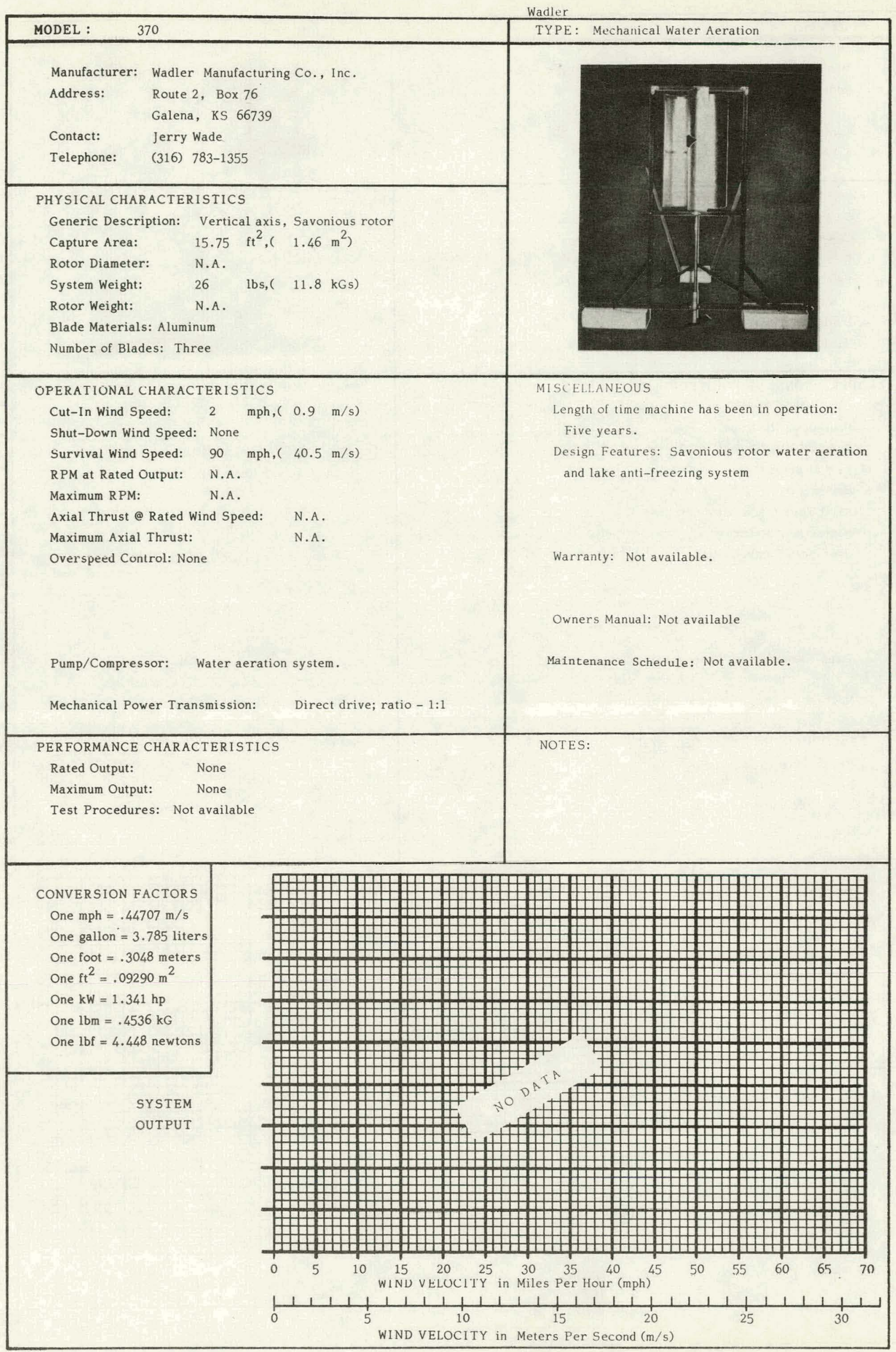




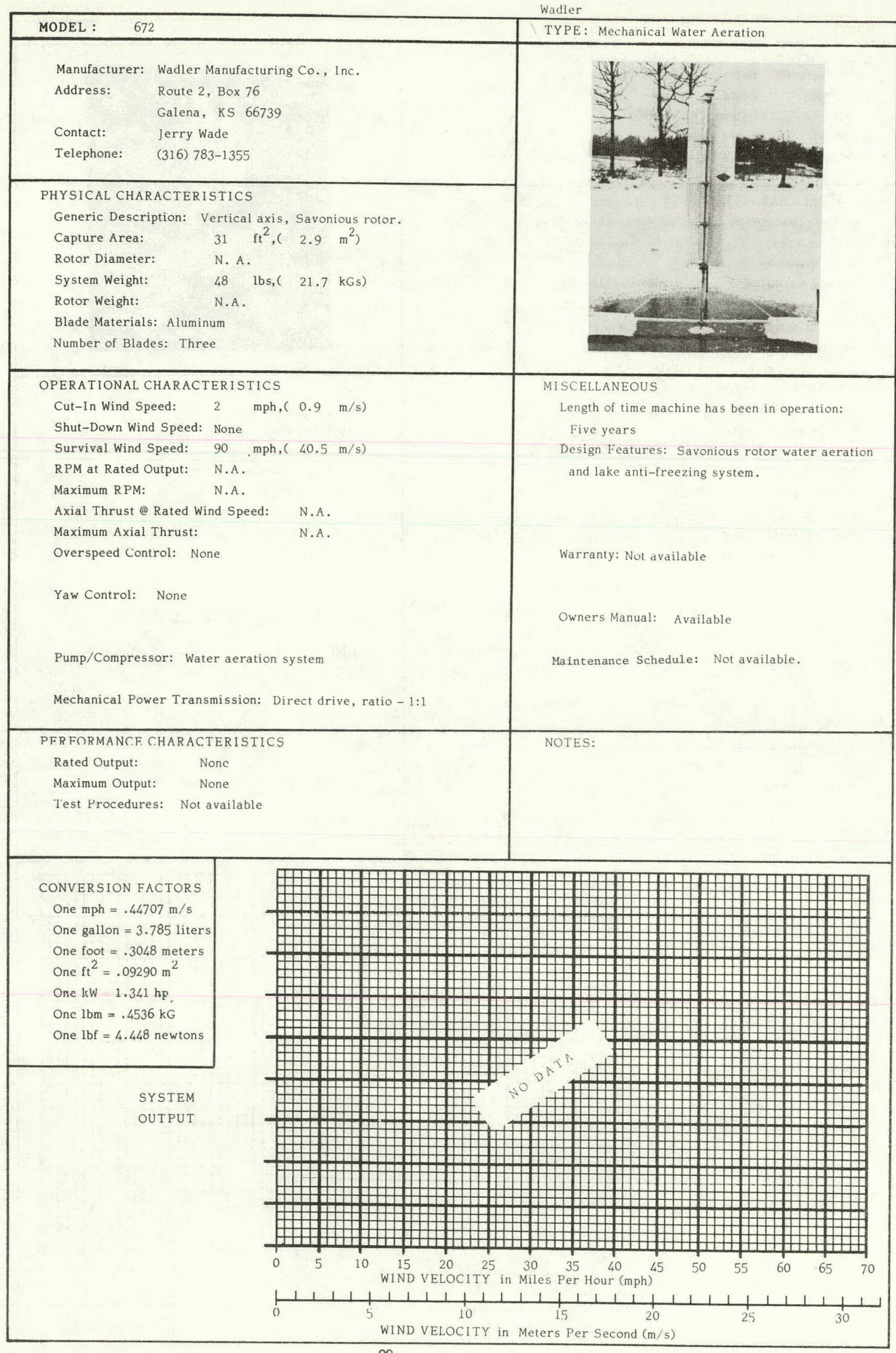


APPENDIX A:

WECS MANUFACTURERS AND DEALERS/OISTRIBUTORS 
Aerolectric

13517 Winter Lane

Cresaptown, MD 21502

Aero Power

2398 Fourth Street

Berkeley, CA 94710

Aerowatt, S.A.

c/o Automatic Power, Inc.

P. 0. Box 18738

Houston, TX 77023

Altos: The Alternate Current

P. 0. Box 905

Boulder, CO 80302

American Wind Turbine, Inc.

1016 East Airport Road

Stillwater, OK 74074

Dakota Wind \& Sun, Ltd.

P. 0. Box 1781

811 First Avenue, NW

Aberdeen, SD 57401

Dominion Aluminum Fabricators

3570 Hawkestone Road

Mississauga, Ontario

Canada L5C 2V8

Dunlite [lectrical Pruducts Co.

Enertech Corporation

P. 0. Box 420

Norwich, VT 05055

Dynergy Corporation

P. 0. Box 428

1269 Union Avenue

Laconia, NH 03246

Grumman Energy systems

4175 Veterans Memorial Highway

Ronkonkoma, NY 11779

Kedco, Inc.

9016 Aviation Boulevard

Inglewood, CA 90301
Contact: Kevin Moran

Telephone: $\quad 609-547-3488$

Contact: John Harold or

Telephone:

Contact: Robert Dodge or

Telephone: $\quad$ Ernest Tindle

Contact: $\quad$ Edward Gitlin

Telephone: 303-442-0885

Contact: Nancy Thedford, Office Manager

Telephone: $\quad 405-377-5333$

Contact: $\quad$ Paul Biorn or

Orv Lynner

Telephone: $\quad 605-229-0815$

Contact: $\quad$ Chuck Wood, Program Manager

Telephone: $\quad 416-270-5300$

Contact: $\quad$ Ed Coffin or $\mathrm{c} / \mathrm{o}$ Robert Sherwin

Telephone: $\quad$ 802-649-1145

Contact: Robert Allen

Telephone: 603-524-8313

Contact: $\quad$ Ed Diamond or

Ken Speiser

Telephone: 516-575-6205

Contact: Wind Program Manager

Telephone: $\quad$ 213-776-6636 
Millville Windmills \& Solar

Equipment Company

P. 0. Box 32

10335 01d Drive

Millville, CA 96062

North Wind Power Company

P. 0. Box 315

Warren, VT 05674

Pinson Energy Corporation

P. 0. Box 7

Marstons Mills, MA 02648

Product Development Institute

508 South Byrne Road

Toledo, $\mathrm{OH} 43609$

Sencenbaugh Wind Electric

P. 0. Box 11174

Palo Alto, CA 94306

Winco

Div. of Dyna Technology

7850 Metro Parkway

Minneapolis, MN 55420

Wind Power Systems, Inc.

P. 0. Box 17323

San Diego, CA 92117

W.T.G. Energy Systems, Inc.

P. 0. Box 87

1 LaSalle Street

Angola, NY 14006

Zephyr Wind Dynamo Company

P. 0. Box 241

21 Stamwood Street

Brunswick, ME 04011
Contact: Devon Tassen

Telephone: $\quad$ 916-547-4302

$\begin{array}{ll}\text { Contact: } & \text { Don Mayer } \\ \text { Telephone: } & 802-496-2955\end{array}$

Contact: Herman Drees

Telephone: $\quad 617-477-2913$

Contact: Tom Nichols

Telephone: $\quad 419-382-0282$

Contact: Jim Sencenbaugh

Telephone: $\quad$ 415-964-1593

Contact: Len Attema

Telephone: $\quad 612-853-8400$

Contact: Ed Salter

Telephone: $\quad$ 714-452-7040

Contact: $\quad$ Al Wellikoff

Telephonè: $\quad 716-549-5544$

Contact: $\quad$ Bill Gillette

Telephone: 207-725-6534 
Aermoter Division

Valley Industries

P. 0. Box 1364

Conway, Arkansas 72032

American Wind Turbine, Inc.

1016 East Airport Road

Stillwater, OK 74074

Dempster Industries, Inc.

P. 0. Box 848

Beatrice, NB 68310

Dynergy Corporation

P. 0. Box 428

1268 Union Avenue

Lacunla, NH 03246

Heller-Aller Company

Perry \& Oakwood Street

Napoleon, $\mathrm{OH} 43545$

Sparco (Denmark)

c/o Enertech, Inc.

P. 0. Box 420

Norwich, VT 05055

Wadler Manufacturing Co., Inc.

Route 2, Box 76

Galena, Ks 66/39
Contact: Stan Anderson

Telephone: $\quad$ 501-329-9811

Contact: Nancy Thedford, Office Manager

Telephone: $\quad 405-223-4026$

Contact: Roy Smith

Telephone: $\quad 402-223-4026$

Contact: Bob Allen

Telephone: 603-524-8313

Contact: James Bradner or Charles Buehrer

Telephone: $\quad 419-592-1856$

Mfg. of Baker Windmills

Contact: $\quad$ Edmund Coffin at Enertech

Telephone: $\quad 802-649-1145$

Contact: Jerry Wade

Telephone: $\quad$ 316-78.3-1355 


\section{WIND MACHINE DEALERS/DISTRIBUTORS}

COMPANY

Aermotor

1243 Majesty Drive

Dallas, TX 75247

Aermotor

2385 South Cherry

Fresno, CA 93706

Aermotor

900 Nabco Avenue

P. 0. Box 1321

Conway, Arkansas 72032

Aermotor

6448 Warren Drive

Norcross, GA 30093

Aermotor

518-M North Douglas Avenue

Altamonte Springs, FL 32701

Aermotor

2421 West Main

Ft. Wayne, IN 46808

Aermotor

4655 Colt Road

Rockford, IL 61109

Aermotor

801 Howard Street

Omaha, NB 68102

Aermotor

8105 Lewis Road

Minneapolis, MN 55427

Aermotor

2803 South Longview Drive

Middletown, PA 17057

Aermotor

1575 Avon Street Extended

Charlottesville, VA 22901

Alternate Energy Systems

150 Sandwich Street

Plymouth, MA 02360
PRODUCT NAME

Aermotor

Contact: Mr. William E. Barney

Telephone: 214-634-1950

Aermotor

Contact:

Telephone: 209-486-7200

Aermotor

Contact: Miles Patten

Telephone: 501-329-2969

Aermotor

Contact:

Telephone: 404-449-1840

Aermotor

Contact:

Telephone: 305-862-0171

Aermotor

Contact:

Telephone: 219-432-2595

Aermotor

Contact:

Telephone: 815-874-9502

Aermotor

Contact: Marvin Vesenik

Telephone: 402-341-1716

Aermotor

Contact:

Telephone: $\quad 612-544-4106$

Aermotor

Contact:

Telephone: 717-939-9311

Aermotor

Contact:

Telephone: 804-977-0445

Elektro, Dunlite, Winco

Contact:

Telephone: 617-747-0771 
Wind Machine Dealers/Distributors (Continued)

COMPANY

Automatic Power, Inc.

P. O. Box 18738

Houston, TX 77023

Dean Bennet Supply Company

4725 Lipan Street

Denver, CO 80211

Clean Energy Products

3534 Bagley, N.

Seattle. WA $981 n .3$

Coulson Wind Flectric

RFD 1, BOX 225

Polk City, IA 50226

Crowdis Conservers

RR 3, MacMillan Mt.

Cape Breton, Nova Scotia

Canada BOE 1 BO

Edmond Scientific Company

380 EDS Corp. B1dg.

101 East Gloucester Pike

Barrington, NJ 08007

Empire Energy Dev lopment Corp.

$33 \% 1$ West Hampden Avenue

Englewood, CA 80110

Environmental .Energies, Ine.

P. 0. Box 73

Front Street

Copemish, MI 49625

Energy Alternatives

52 French King Highway

Greenfield, MA 01301
PRODUCT NAME

Aerowatt

Contact: Robert Dodge

Telephone: 713-228-5208

Aermotor, Dunlite, Winco

Contact: Deana Bennet

Telephone: 303-433-8291

Jacobs, Kedco, Sencenbaugh, Wincharger

Contact. Ed Kennell

Telephone: 206-633-5505

Re-conditinned Jacobs, Winco, Winpower

Contact: $R$, Coulson

Telephone: $\quad 515-547-3488$

North Wind

Contact: Daniel Atkins

Aerolectric (Wind Wizard)

Contact: Robert $\dot{F}$. McKelvery

Telephone: 609-547-3488

Altina, Winco

Contact: David L. Flook

Telephone: 303-789-1363

Elektro, Dunlite, Re-conditioned Jacobs

Contact: Timothy J. Horning

Telephone: 616-378-2000

Elektro, Dunl ile, Winco, Sencenbaugh

Contact: Frank Kaminsky or Klaus Kroner

Telephone: $\quad$ 413-773-5175 
Wind Machine Dealers/Distributors (Continued)

COMPANY

Energy Development Company 17.9E Road \#2

Hamburg, PA 19526

Energy - 2000

Route 800 , RFD \#3

Winstead, CT 06098

Enertech Corporation

P. 0. Box 420

Norwich, VT 05055

Environmental Resource Group

Box 3A, RD 2

Williston, VT 05495

Fenton's Feeders

Route 1, Box 124

Arcadia, FL 33821

Independent Energy Company

314 Howard Avenue

Ewarthmore, PA 19081

Independent Energy Company

6043 Sterrettania Road

Fairview, PA 16415

Kramco

P. 0. Box 1536

Allentown, PA 18105

Laholms Motor \& Bilelektriska A/B

Export Office \& Information

Wind Kraft A.E.S.C.

Box \#104

S-312 01 Laholm, Sweden

Makia Ocean Engineering

Box 1194

Kailua, Oahu, Hawaij 96734

\section{PRODUCT NAME}

Winco, Homebuilt

Contact: Terrance or Helena

Mehrkam or

Karen Votyas

Telephone: $\quad$ 215-562-8856

Re-conditioned Jacobs (North Wind)

Contact: Robert Hebert

Telephone: 203-379-5185 or

413-528-3440

Dunlite, Winco, Sencenbaugh, Sparco

Contact: E. Coffin

Telephone: 802-649-1145

North Wind, Sparco

Contact: Perry Kleine

Telephone: $802-879-0511$ or

802-878-4000

Aermotor (Water pumping)

Contact: Catherine Fenton, Bill Autry, or Ne 11 Gammage

Telephone: $817-494-2727$

Elektro, Dunlite, Winco

Contact: Kendall B. Hampton

Telephone: 617-368-6992

Re-conditioned Jacobs, Dakota

Wind Electric

Contact: John D'Angelo

Telephone: 814-833-0829

Re-conditioned Jacobs, Winco

Contact:

Telephone: 215-437-6758

Wind Kraft A.E.S.C.

Contact: Eric Alkstad

Int. Phone: 00946-43020371

Cable: WERKOMP

Dunlite

Contact: Henry Horn

Tolephone: 808-259-5904 or

808-259-5722 


\begin{tabular}{|c|c|}
\hline COMPANY & PRODUCT NAME \\
\hline $\begin{array}{l}\text { Natural Power Systems, Inc. } \\
3316 \text { Augusta Avenue } \\
\text { Omaha, NB } 68144\end{array}$ & $\begin{array}{l}\text { Dakota Wind Electric, Dunlite, } \\
\text { Sencenbaugh, Sparco } \\
\text { Contact: } \quad \text { John Traudt } \\
\text { Telephone: } 402-334-5881\end{array}$ \\
\hline $\begin{array}{l}\text { O'Brock Windmill Sales } \\
\text { Route } 1 \text {, 12th Street } \\
\text { North Benton, OH } 44449\end{array}$ & $\begin{array}{ll}\text { Baker } & \\
\text { Contact: } & \text { Ken O'Brock } \\
\text { Telephone: } & 216-584-4681\end{array}$ \\
\hline $\begin{array}{l}\text { Pacific Energy Systems } \\
615 \text { Romero Canyon Road } \\
\text { Santa Barbara, CA } 93018\end{array}$ & $\begin{array}{ll}\text { North Wind } & \\
\text { Contact: } & \text { Fred Carr } \\
\text { Telophone: } & 805-969-6603\end{array}$ \\
\hline $\begin{array}{l}\text { Prairie Sun \& Wind Company } \\
4408-62 \text { nd Street } \\
\text { Lubbock, TX } 79409\end{array}$ & $\begin{array}{l}\text { Re-conditioned Jacobs, Winco, } \\
\text { Aeropower, Dakota Wind Electric } \\
\text { Aermotor } \\
\text { Contact: } \quad \text { Ken Ketner } \\
\text { Telephone: } 806-795-1412\end{array}$ \\
\hline $\begin{array}{l}\text { Real Gas \& Electric } \\
\text { P. 0. Box } 193 \\
\text { Shingletown, CA } 96088\end{array}$ & $\begin{array}{l}\text { Elektro, Dunlite } \\
\text { Contact: } \quad \text { Solomon Kagin } \\
\text { Telephone: } \quad 916-474-3852\end{array}$ \\
\hline $\begin{array}{l}\text { Rede Corporation } \\
\text { P. 0. Box } 212 \\
\text { Providence, RI } 02901\end{array}$ & $\begin{array}{ll}\text { Dominion Aluminum Fabricating (DAF) } \\
\text { Contact: } & \text { Ronald Beckman } \\
\text { Telephone: } & 401-751-7333\end{array}$ \\
\hline $\begin{array}{l}\text { Schupbach, Ralph } \\
321 \text { - 13th Street } \\
\text { Alva, OK } 73717\end{array}$ & $\begin{array}{ll}\text { Winco } & \\
\text { Contact: } & \text { Ralph Schupbach } \\
\text { Telephone: } & 405-327=1685\end{array}$ \\
\hline $\begin{array}{l}\text { Shingletown Electric } \\
\text { P. 0. Box } 237 \\
\text { Shingletown, CA } 96008\end{array}$ & $\begin{array}{l}\text { Elektro, Dunlite } \\
\text { Contact: } \quad \text { Robert E. Eckert } \\
\text { Telephone: } \quad 316-474-3852\end{array}$ \\
\hline $\begin{array}{l}\text { Sunflower Power Company } \\
\text { Route } 1 \text {, Box 93-A } \\
\text { Oskaloosa, KS } 66066\end{array}$ & $\begin{array}{ll}\text { Re-conditioned Jacobs, North Wind } \\
\text { Contact: } \quad \text { Steve Blake } \\
\text { Telephone: } & 913-597-5603\end{array}$ \\
\hline $\begin{array}{l}\text { Wind Engineering Corporation } \\
\text { Box } 5936 \\
\text { Lubbock, TX. } 79417\end{array}$ & $\begin{array}{l}\text { Re-conditioned Jacobs, DAF, } \\
\text { Dynergy, Dakota Wind Electric } \\
\text { Contact: } \\
\text { Telephone: } 806-763-3182\end{array}$ \\
\hline $\begin{array}{l}\text { Windependence Electric } \\
\text { P. O. Box M1188 } \\
\text { Ann Arbor, MI } 48106 \text {. }\end{array}$ & 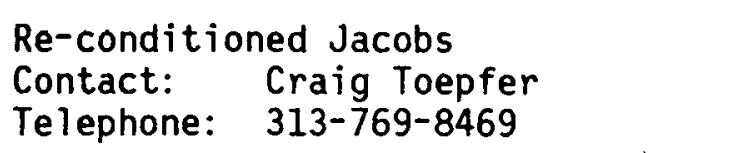 \\
\hline
\end{tabular}


APPENDIX B:

SUBSYSTEM COMPONENTS AND SUPPLIERS

ANEMOMETERS

TOWERS

BATTERIES

INVERTERS 
Anemometers are devices which measure the wind. The manner in which they accomplish this task ranges from an odometer which records the number of miles of wind that pass the recorder, to three-axis anemometers that record wind velocity on three separate planes.

As with all wind system sub-components, anemometers vary widely in terms of accuracy, the type of information obtained, and cost. The value of a certain anemometer or anemometry system will depend largely upon the specific application for which it is used. Again, wind system distributors can help select the proper anemometer or anemometry system.

Dwyer Instruments, Inc.

Box 373

Michigan City, IN 46360

Taylor Instruments

Arden; NC 28704

Bendix Environmental Science Division 1400 Taylor Avenue

Baltimore, MD 21204

Climet Instruments Company

1620 West Colton Avenue

Redlands, CA 92373

Kahl Scientific Instrument Corp.

Box 1166

El Cajon

San Diego, C.A 92022

Davis Instrument Mfg. Co., Inc.

513 East 36th Street

Baltimore, MD 21218

Natural Power

New Boston, NH 03070
Aircraft Components

North Shore Drive

Benton Harbor, MI 49022

Danforth

Div. of the Eastern Company

Portland, Maine 04103

Meteorology Research, Inc. Box 637

Altadena; CA 91001

Robert E. White Instruments, Inc. 33 Commercial Wharf

Boston, MA 02110

Texas Electronics, Inc. 5529 Redfield Street. Box 715. Inwood Station Dallas, TX 75209

Maximum, Inc. 8 Sterling Drive Dover, MA 02030 


\section{WTG TOWERS}

All wind machines must be placed on a support structure, generally a tower. A variety of factors influence the final choice of a tower for a particular wind machine and application. Two tower types, guyed and free-standing, are applicable for most wind energy installations.

Wind system distributors can help select the best tower for a particular site, but several factors should be considered. Wind machines should be at least 30 feet above the nearest obstruction: The tower must also support the weight of the wind machine and withstand loads imposed by the wind. These loads are a function of both the wind velocity and wind machine rotor diameter. Aesthetics, building codes, and zoning are also considerations in some areas.

There are four American Manufacturers of towers designed specifically for WECS. A number of foreign manufacturers offer their towers through WTG distributors. In addition, there are a number of tower manufacturers who have not been active in the WECS field but may have suitable equipment.

Naturał Power Inc.

Francestown Turnpike

New Boston, NH 03070

North Wind Power Company

Box 315

Warren, VT 05674

Unarco-Rohn

6718 West Plank Road

P. 0. Box 2000

Peoria, IL 61601

Bayshore Concrete

Bayonne, NJ 


\section{BATTERIES}

Because the wind is an intermitent energy source, it is often necessary to find a means of storing its energy. Although many energy storage systems such as heat, compressed air and flywheels are now being investigated, the state-of-the-art for electricity storage is the lead acid battery.

There are several types of storage batteries new commercially available. Each type has characteristics that make it best suited for a particular application. The ultimate choice of batteries depends on the total wind system characteristics including wind at the site, the wind turbine generator, and the load.

Balleries Manufacluring Company 14694 Dequindu

Detroit, MI 48212

Bright Star

602 Getty Avenue

Clifton, NJ 07015

Burgress Div. of Clevite Corp., Gould

Box 3140

St. Paul, MN 55101

C \& D Batteries Eltuce Corp. Washington \& Chewy Street

Conshohocken, PA 19428

Delatron Systems Corporation

553. Lively Boulevard

Elk Grove Village, IL 6007

Delco-Remy Division of GM

Box 2439

Anderson, IN 46011

Eggle-Pichen Industries

Box 47

Joplin, MO 64801

ESB Incorporated - Willard

Box 6949

Cleveland, $\mathrm{OH} \quad 44101$

Exide

5 Pen Center Plaza

Phịladelphia, PA 19103
Ever Ready - Union Carbide Corp. 270 Park Avenue

New York, NY 10017

Globe-Union

5757 N. Greenbay Avenue

Milwaukee, WI 53201

Gould Incorpurated

485 Calhoun Street

Trenton, NJ 08618

Gulton

212 T Dorham Avenue

Metuchen, NJ 08840

Keystone Battery Company

8301 Imperial Drive

Waco, TX 76710

Mule Battery Company

325-T Valley Street

Providence, RI 02908

$\mathrm{RCA}$

$\overline{415}$ South 5th Street

Harrison, NJ 07029

Surrette Storage Battery Co., Inc. Box 711

Salem, MS 01970 


\section{INVERTERS}

Inverters are devices that convert direct current power (DC) to the alternative current $(A C)$ more commonly used in this country.

There are a number of considerations in selecting an inverter for a WECS including the amount and quality of the power required, overload capabilities, and cost.

The majority of these systems are designed to operate with a battery bank storage system and are known as "stand alone" inverters. There is also available an inverter known as a synchronous inverter or "line commutated' inverter. These inverters are designed to feed the power produced to an A.C. line and requires the A.C. line for a voltage signal.

It should be noted that there are quite a few inverter manufacturers and most wind turbine generator distributors also sell inverters.

Allied Electronics

$2400 \mathrm{~W}$. Washington Blvd.

Chicago, IL 60612

(312) $421-4200$

Eico Electronic Instrument Co.

283 Malta Street

Brooklyn, NY 11207

Electro Sales Co., Inc.

$100 \mathrm{Fe} 11$ sway West

Somerville, MA 02145

(617) $666-0500$

Heath Company

Benton Harbor, MI 49002

(616) 983-3961

LaMarche Mfg. Company

106 Bradrock Drive

Des Plaines, IL 60018

(312) 279-0831

Newark Electronics

500 N. Pulaski Road

Chicago, IL

(312) $638-4411$

Nova Electric

$263 \mathrm{Hills}$ ide Avenue

Nutley, NJ 07110

(201) $661-3432$
350 to 1000 watt; 12 volt input

110 to 220 watt; 12 volt input

20 to 2000 watt; 12 to 200 volt input

175 watt; 12 volt input

100 to 10000 watt; 24 to 120 volt input

100 to 250 watt; 12 volt input

30 to 120 watt; 12 to 110 volt input 
Ratelco, Inc.

610 Pontius Avenue, $\mathrm{N}$.

Seattle, WA 98109

(206) 624-7770

Soleq Corporation 59.69 Elston Avenue Chicago, IL 60646

(312) 792-3811

Topaz Electronics 3855 Ruffil Road

San Diego, CA 92123

(714) 279-0831

Willmore Electronics Box 2973

Durham, NC 27705

(919) 489-3318

\section{LINE COMMUTATED INVERTERS}

Gemini Synchronous Inverters Windwark.s

Box 329, Route 3

Mukwonago, WI 53149

(414) 363-4408
250 to 2500 watt; 24 to 100 volt input

1500 to 6000 watt; 12 to 112 volt input

200 to 3000 watts; 12 to 125 volt input

45 to 1500 wall; 12 to 120 volt input

4 to $1000 \mathrm{kw}$; variable voltage input 

APPENDIX C:

SELECTED REFERENCES ON WECS

$-113=$ 


\section{SELECTED REFERENCES ON WIND ENERGY CONVERSION SYSTEMS}

\section{BIBIOGRAPHIES}

1. Energy from the Wind, 1977

CER-74-75 BLB-RNM-44

Burke, B. L. and Merony, R. N.

Available from:

Engineering Sciences Branch Library

Engineering Research Center

Colorado State University

Foothills Campus

Ft. Collins, Co 80523

(Cost/Copy \$12.95)

A comprehensive, annoted bibliography of general and technical wind energy references, articles, and publications. Best suited for general research work. Updates will be available on a regular basis.

\section{BOOKS}

2. Power from the Wind, 1948

Putnam, P.C.

Available from:

Von Nostrand Reinhold Co.

450 West 33rd Street

New York, NY 10001

An excellent historical account of the Smith-Putnam wind turbine project of 1934-1935. This Smith-Putnam turbine was the largest wind generator built to date, (its blades spanned 175 feet) and fed $1200 \mathrm{kw}$ of power into the grid network of Central Vermont utilities whenever the wind exceeded $17 \mathrm{mph}$. 
3. Wind-Catchers, 1976

Torrey, $v$.

Available from:

Stephen Green Press

Brattleboro, VT 05301

(Cost/Copy $\$ 12.95$ )

A general historical overview of the use of wind energy systems from the first early water-pumpers ( $900 A D$ ) through the varied present-day applications. An excellent series of photos accompany the text.

4. Wind Machines, 1975

Stock \# 038-000-00272-4.

Eldridge, $F$.

Available from:

Superintendent of Documents

Government Printing Office

Washington, D.C. 20402

One of the best introductory references on wind energy. A review of the history, viability, taxonomy, and potential of wind machines for energy needs. Includes photos and graphics of various wind energy systems.

5. Simplified Wind Power Systems for Experimenters, 1976

Park, J.

Available from:

Helion

Box 445

Brownsville, CA 95919

As the title implies, this book presents a simplified analysis of wind energy systems. Overall, it provides a review of the aerodynamic, structural, and mechanical design of the wind rotor, power sturaye, and the entirc wind energy conversion system. 
6. Applied Aerodynamics of Wind Power Machines, 1974

Wilson, R. E. and Lissaman, P.B.S.

Available from:

National Technical Information Service

U.S. Department of Commerce

5285 Port Royal Road

Springfield, VA 22161

(PB-238-595)

(Cost/Copy \$5.25)

7. Aerodynamic Performance of Wind Turbines, 1976

Wilson, R. E., Lissaman, P.B.S., and Walker, S. N.

Available from:

Natfonal Technical Information Service

U.S. Department of Conmerce

5285 Port Royal Road

Springfield, VA 22161

(PB-259-089)

(Cost/Copy $\$ 5.25$ )

Both of these highly technical publications review the aerodynamics of various types of wind power machines and the relative sucess of various means of extracting power from the wind, The methods revicwed are intellued to be of use in the rapid evaluation and comparitive analys is of the aerodynamic performance of wind energy systems.

8. The Generation of Electricity by Wind Power, 1955

Golding, E. W.

Available from:

Halsted Press

A Division of John Wiley \& Sons, Inc.

605 Third Avenue

New York, NY 101016

(Cost/Copy $\$ 19,95$ )

A classic wind energy pubiication originally written in 1955 by one of the pioneers in the wind energy field. The book provides a comprehensive review of wind characteristics, the design and operation of wind machines and the economics of wind energy systems in different applications. The revised 1976 edition of the book includes an additional chapter on recent developments in the wind energy field by R. I. Horres, a former colleague of the late Mr. Golding. 
9. Wind Power for Farms, Homes and Small Industry

Scheduled for late 1978

Nielsen Engineering and Research, Inc.

Available from:

National Technical Information Service

U.S. Department of Commerce

5285 Port Royal Road

Springfield, VA 22161

The publication is designed to provide information to enable farmers, home-owners, and other prospective small machine buyers to evaluate their energy needs and access the value and utility of wind systems in meeting those needs.

10. Summary Report-Federal Wind Energy Program, January 1, 1977 (ERDA-77-32)

Energy Research and Development Administration

Division of. Solar Energy

Wind Systems Branch

Available from:

Superintendent of Documents

U.S. Government Printing Office

Washington, D.C. 20402

(Stock No. 060-000-00048-4)

(Cost/Copy $\$ 1.15$ )

A detailed summary of the overall-FY 1976 federal projects that are wind-related. Of particular interest is the listing of individual projects that details the principal investigator, the grant amount, background, objectives and approach, and preliminary output.

11. Federal Wind Energy Program, Summary Report, January 1978

U.S. Department of Energy

Division of Solar Technology

Wind Systems Branch

Available from:

Superintendent of Documents

U.S. Government Printing office

Washington, D.C. 20402

(Stock No. 061-000-00050-0)

An up-dated summary of the federal program, including all projects funded during FY 1977. 
12. Wind Power Climatology of the United States

Sandia Laboratories

Available from:

National Technical Information Service

U.S. Department of Commerce

5285 Port Royal Road

Springfield, VA 22161

(Cost/Copy $\$ 7.60)$

13. The Climatic Atlas of the United States

Available from:

Environmental Dat.a Service

National Climatic Center

Federal Building

Asheville, NC 28801

(Cost/Copy \$4.95)

14. United States Wind Speed and Wind Power Duration Tables, by Months (Cumulative Distributions).

(Scientific Report No. 1)

Coty, U. A. ; Court, A; Reed, J. W.

Avallable from:

National Technical Information Service

U.S. Department of Commerce

5285 Purl Rnyal Road

Springfield, VA ..22161.

Cumulative distributions of wind speed (meters per second), adjusted to a standard height of 10 meters ( $33 \mathrm{feet}$ ) above ground at 478 places in the United States, for each month and season, and for the year as a whole, are contained in this' report. Also yives cumulative distributions of wind power (watts per square meter), by seasons and for the year at heights of 10,50 and 100 meters above ground. 


\section{PROCEEDINGS}

15. Proceedings of the Vertical Axis Wind Turbine Technology Workshop, 1976

Available from:

National Technical Information Service

U.S. Department of Commerce

5285 Port Royal Road

Springfield, VA 22161

(Cost/Copy $\$ 13.75$ )

A compilation of the papers presented at the workshop in the following areas: Wind Energy Programs, DOE's Darrieus Vertical Axis Wind Turbine Program, and other prominent vertical axis wind programs. This is primarily technical information.

16. Proceedings of the Second Workshop on Wind Energy Conversion Systems, Washington, D.C., June 9-11, 1975

Eldridge, F.

Available from:

Superintendent of Documents

U.S. Government Printing office

Washington, D.C. 20402

(Stock No. 038-000-00258-9)

(Cost/Copy $\$ 10.00)$

These proceedings include papers presented in virtually every area of ERDA's wind energy programs. Large systems (100 kw or larger), mission and regional analysis, international activities, technology development, energy storage, wind characteristics, institutional issues, and working group reports.

17. Proceedings of the American Wind Energy Association Conferences, 1976-1977

Available from:

The American Wind Energy Association

54468 CR 31

Bristol, Indiana 46507

(Available, Fall 1977)

A collection of the proceedings of two major national conferences sponsored by AWEA. The work of the entire wind energy field is represented here including papers from William Heronomous (U. Mass. Wind Energy Project), David Spera (NASA), Terry Healy (Rocky Flats Wind System Test Center), Dr. L. H. Soderholm (Iowa State University), Jack Park (Helion), and William Hughes (American Wind Turbine). 


\section{BOOKLETS}

18. Planning a Wind-Powered Generating System, 1977

Enertech Corporation

P. 0. Box 420

Norwich, VT 05066

A short primer in the basic principles of wind machines, their components, and siting requirements. Includes estimations of power requirements and details of site, tower, and battery storage selections. A "cookbook" for the handyman.

19. Wind Power

Syverson, P. E., Symons, J. G.

Available from:

Wind Power

Box 233

Mankato, MN 56001

(Cost/Copy $\$ 3.50)$

A solid introductory work on the components and uses of wind energy systems that is suited for both general and technical readers. This booklet is particularly strong on system planning and engineering.

\section{PERIODICALS}

20. Wind Power Digest

Edited by Michael Evans

Available from:

Jester Press

54468 CR 31

Bristol, Indiana 46507

(Cost $\$ 6.00$ per year, published quarterly)

An nngning snurre for current information on available wind energy hardware, accessories, publications and reports from people working in the field. 
21. The Wind Technology Journal

Edited by Carolyn and Herman Drees

Available from:

Wind Technology Journal

P. 0 . Box 7

Marston Mills, MA

(Cost $\$ 20.00$ per year. $\$ 15.00$ for members of the American Wind Energy Association. $\$ 40.00$ per year for institutions. Published quarterly)

This new publication (published by the American Wind Energy Association) fills the need for up-to-date technical information. The information presented is useful to both general and technical audiences.

22. AWEA News letter

Available from:

Wind Technology Journal

P. 0 . Box 7

Marston Mills, MA

(Cost $\$ 10.00$ per year, published quarterly)

The official publication of AWEA dedicated to communication between AWEA Members and interested, non-affiliated individuals as well. Editorally it features news of AWEA organizational activities and industry and product reports.

\section{ENERGY-GENERAL}

23. A Time to Choose, 1974

Ford Foundation Energy Policy Project

Available from:

J. B. Lippincott

East Washington Square

Philadelphia, PA 19105

(Cost/Copy \$4.95)

A review of the energy options open to the U.S. through the year 2000. There is a particular emphasis on energy use and tts implications. 